\title{
FUJIMORI. LA LUCHA POR LA DEFENSA DE LOS DERECHOS HUMANOS EN LA HISTORIA RECIENTE DEL PERÚ
}

\section{FUJIMORI. THE STRUGGLE FOR HUMAN RIGHTS IN RECENT HISTORY OF PERU}

\begin{abstract}
Carlos Gamero Esparza: Universidad Inca Garcilaso de la Vega (Perú) carlos.gamero@ozu.es
\end{abstract}

\section{CURRÍCULUM VITAE}

Reconocido Periodista peruano del Diario OJO de Lima. Licenciado con Diploma de Honor en la Universidad Inca Garcilaso de la Vega.

\section{RESUMEN}

El ex presidente, y ex dictador, Alberto Fujimori, se encuentra recluido en un centro de la Dirección de Operaciones Especiales de la Policía Nacional del Perú, en espera de ser condenado por la justicia peruana, que lo viene juzgando por sus crímenes dentro del marco del juicio más grande jamás visto en nuestra historia republicana. Aquí, pues, la verdad, la gran verdad es que un 12 de julio de 1993, en medio de la agitación y violencia que se vivía en el país, la revista Oiga publicaba una denuncia periodística que tituló: Historia de una traición o el "Plan Verde". Fue un documento que marcó el inicio de una de las peores dictaduras de la historia, la de Fujimori. El exterminio de lo que ellos denominaban excedente poblacional o excedentes poblacionales nocivos fue tal vez uno de los puntos más controvertidos. Tales 
estrategias se llevaron a cabo en las zonas andinas y en la amazonia peruana. Los familiares de las víctimas reclaman justicia y reparación de algo irreparable. Mientras, los seguidores del ex presidente se empeñan cínicamente en continuar negando la responsabilidad de Fujimori y quieren seguir creyendo que su líder era un gran presidente.

\section{PALABRAS CLAVE}

Fujimori - Plan Verde - Dictador - Muertos

\section{ABSTRACT}

The former president and former dictator, Alberto Fujimori, is being held in a center of the Directorate of Special Operations of the National Police of Peru, waiting to be sentenced by the Peruvian justice system, it is judged for their crimes within the framework the largest judgment ever in our republican history. Here, then, the truth, the great truth is that a July 12,1993, amid the turmoil and violence that existed in the country, the magazine published a report Listen journalistic titled: History of a betrayal or "Green Plan. "It was a document that marked the beginning of one of the worst dictators in history, that of Fujimori. The extermination of what they called surplus population and surplus population was perhaps damaging one of the most controversial. Such strategies were carried out in the Andes and the Peruvian Amazon. Relatives of the victims seeking justice and redress of something irreparable. Meanwhile, supporters of former president cynically strive to continue denying the responsibility of Fujimori and want to continue believing that their leader was a great president. 


\section{KEY WORDS}

Fujimori - Green Plan - Dictator - Dead

\section{ÍNDICE}

1. Introducción. El "Plan" que trajo un pajarillo verde

2. Algo que se ha querido ocultar al mundo... hasta ahora: "El Gobierno calla ¿política de exterminio?"

3. El "Pajarillo verde" que nadie hizo caso... -salvo Oiga - o la historia de una traición ignorada contra el pueblo peruano

4. El "Plan" que trajo un pajarillo verde... 2 2 Parte

5. Vergüenza de no haberle hecho caso...

6. ¿Sabía usted qué...

7. Para saber más

8. Epilogo: Los últimos días de Oiga

9. Notas al margen y referencias

TEXTO:

\section{Introducción: El "Plan" que trajo un pajarillo verde}

El 12 de julio de 1993, la revista Oiga de Francisco Igartua denunció en dos reportajes a los presuntos autores de las matanzas indiscriminadas que en ese entonces venía perpetrando con total impunidad un comando armado denominado "Grupo Colina" que operaba bajo las órdenes de un sanguinario mayor del Ejército peruano, de 
nombre Santiago Martín Rivas, quien contaba con la anuencia del entonces presidente de la República, Alberto Fujimori y, de paso, dio cuenta de la existencia de un oculto proyecto de gobierno, el llamado "Plan Verde", en un informe que fue publicado en dos ediciones de la revista.

En las páginas de este reportaje-denuncia, Francisco Igartua advertía de lo que algunos sospechaban pero no se atrevían a abrir la boca: la existencia de un "triunvirato" del poder conformado por el hoy preso y procesado ex presidente Alberto Fujimori, su "asesor" del Servicio de Inteligencia Nacional, Vladimiro Montesinos Torres, y el general Nicolás Hermoza Ríos, entonces Jefe de las Fuerzas Armadas del Perú, que estaba manejando los destinos del Perú desde 1990, bajo los lineamientos del citado documento, que había sido redactado en 1989 al interior de un instituto castrense. Era un texto, valga redundancia, secretísimo, ignorado por la la opinión pública nacional e internacional, cuya existencia fue puesta en evidencia gracias al gesto de un valiente pajarillo verde que lo hizo llegar a la redacción de Oiga. Ni corta ni perezosa, Oiga presentó su fundamentada denuncia acerca del contenido de dicho "plan" que, lamentablemente, desoyeron los paisanos y colegas del director de este semanario, pese a los llamados de atención y exhortaciones a la prensa peruana para que ésta tomara consciencia sobre el peligro dictatorial que amenazaba con hacerse largo y añoso. Fue una denuncia contundente que trajo por postrer consecuencia una atroz persecución y el cierre de muchos medios periodísticos independientes, entre estos, la revista Oiga, amén de que se acentuó la aplicación de los lineamientos del "Plan Verde" para efectos de la democracia dirigida fujimorista.

Por esto decidimos acometer este esfuerzo periodístico para Vivat Academia, en la forma de un trabajo que empieza con el reportaje Algo que se ha querido ocultar... hasta ahora: "El Gobierno calla ¿política de exterminio?". (capítulo 1), que, además de 
describir los pormenores del atroz crimen de los nueve alumnos y un profesor de la Universidad Tomás y Valle de La Cantuta -en el distrito de Chosica, al este de Lima -, da detalles sobre la matanza de Barrios Altos y da un adelanto, a manera de primicia, acerca del "plan secreto de gobierno", materia del reportaje Historia de una traición (capítulo 2 de este trabajo), el mismo que fuera publicado en una primera parte en aquella histórica edición de Oiga del 12 de julio de 1993. Este "plan" no era otro que el verdadero proyecto de gobierno secretísimo -según expresión de Paco Igartua - con el que Alberto Fujimori y sus secuaces pretendían perpetuar una dictadura nunca antes vista en el Perú; en las líneas que siguen a continuación se podrá comprobar, con pruebas al canto, que la ejecución de este "proyecto" ya se estaba aplicando a espaldas del pueblo peruano cuando Oiga presentó la primera parte del informe que denunciaba la existencia desde 1989 de este documento "oficial" o "Plan Verde", ocultado deliberadamente a la opinión pública pese a la promesa de Fujimori de publicar su "plan de gobierno", cosa que no se hizo pero se llevó a la práctica. Una semana después, se publicaría la segunda parte de este informe bajo el título Los 'Anexos' del golpe de Fujimori (que aquí figura en el capítulo 3), publicado el 19 de julio de aquel mismo año.

El cuarto capítulo lo hemos titulado Vergüenza de no haberle hecho caso, la historia de la vergonzosa e indolente actitud de la prensa peruana y la sociedad civil ante las evidencias presentadas por Oiga sobre los abusos de poder, los asesinatos indiscriminados y las violaciones de los Derechos Humanos que estaba cometiendo el régimen de Alberto Fujimori en medio de la total indiferencia de la opinión pública, que creía que el "japonés presidente" era "un gran gobernante" y que su "democracia" era una "maravilla". Una "maravilla", empero, que él mismo se había encargado de pisotear con su "autogolpe" del 5 de abril de 1992. Paco Igartua expresa aquí su preocupación por el sombrío destino del Perú bajo esta dictadura encubierta y advierte a la opinión pública, especialmente a sus colegas periodistas, sobre la 
aplicación del siniestro "plan" de gobierno que ya se estaba ejecutando, pero esta advertencia tuvo por respuesta el silencio de los inconscientes, era como la bíblica voz del que grita en el desierto: el país estaba mareado por el "ritmo del chino"; finalmente, en Epílogo: Los últimos días de Oiga (capítulo 7) relatamos la casi desconocida historia del acoso financiero y tributario que llevaron al cierre de la revista Oiga, cuyo número del adiós apareció en los quioscos el 5 de septiembre de 1995. El semanario de Paco Igartua fue obligado a salir de circulación precisamente por haberse atrevido, dos años atrás, a publicar las demoledoras evidencias contra el criminal accionar del régimen "cívico-militar" implantado por Fujimori y un grupo de malos militares y políticos corruptos que hicieron uso y abuso de sus prerrogativas y atribuciones de tan mala manera.

\section{Algo que se ha querido ocultar al mundo... hasta ahora: "El Gobierno calla ¿política de exterminio?"}

El viernes, cuando se esperaba la reanudación de los trabajos de excavación y búsqueda de nuevas fosas, no apareció ninguna autoridad. El doctor Víctor Cuba Villanueva, uno de los fiscales que estuvieron en Cieneguilla el jueves, habría dicho que las excavaciones habían sido suspendidas al no haber indicios sobre la existencia de otras tumbas. ¡Qué curioso!, el doctor Cuba es el mismo fiscal que intervino en la matanza de Barrios Altos y no descubrió nada; también es el mismo que 'investigó' la denuncia de doña Susana Higuchi contra sus cuñados, a quienes acusó de aprovecharse de las donaciones extranjeras, y tampoco encontró nada doloso. El doctor Cuba es el fiscal ad hoc por excelencia; uno de los pocos que sobrevivió a la razzia de fiscales y magistrados ejecutada por Fujimori tras el golpe del 5 de abril del 92.

De: Algo que se ha querido ocultar al mundo... hasta ahora: "El Gobierno calla ¿política de exterminio?". 
Revista Oiga, 12 de julio de 1993 (Nota 24)

Hoy, el ex presidente -y ex dictador - Alberto Fujimori se encuentra recluido en un ambiente de la Dirección de Operaciones Especiales de la Policía Nacional del Perú DINOES - en espera de ser condenado por la justicia peruana, que lo viene juzgando por sus crímenes dentro del marco del "megajuício" más grande jamás visto en nuestra historia republicana; se trata de un proceso contencioso que de alguna forma pretende devolverle la dignidad, que sino la salud moral, a un Estado y a un país embarrados hace tiempo por obra de ciudadanos indignos que convirtieron la honra nacional en estiércol. Por su parte, Vladimiro Montesinos Torres, su "socio" y ex asesor de la dictadura, el llamado "poder tras la sombra", quien, desde el otrora Servicio de Inteligencia Nacional (SIN) -en aquella famosa salita de los "vladivideos" por donde desfilaron desde vedettes de la televisión hasta empresarios, congresistas, líderes políticos y sindicales, deportistas, artistas, intelectuales, etc., etc. - , corrompió y envileció conciencias, comprando voluntades mediante la extorsión, la coima y el soborno, también está preso en la Base Naval del Callao, procesado por distintos delitos y crímenes cometidos cuando era el todopoderoso hombre del régimen. Igualmente está encarcelado, en la misma base del Callao, el general (r) Nicolás Hermoza Ríos, el tercer hombre fuerte de la dictadura y ex jefe de las Fuerzas Armadas, quien acaba de ser condenado a 8 años de prisión efectiva por corrupción y actualmente afronta otros procesos por las matanzas de Barrios Altos (1991) y La Cantuta (1992) que, seguramente, le sumarán largos años de encierro a los que ya viene cumpliendo. $\mathrm{Y}$ con ellos también están purgando condena casi todos los "colaboradores" de aquel gobierno cívico militar que gobernó el Perú ejecutando un proyecto político que había sido preparado a espaldas de la ciudadanía, lo cual configuraba una verdadera "sacada de vuelta" al país, pues durante su campaña electoral previa a las elecciones de 1990 Fujimori había prometido dar a conocer su "plan de gobierno", cosa que jamás hizo. Y con los aludidos "peces gordos" en la 
"cana", como se diría jergalmente, otros "pescaditos" no tan obesos también la están viendo negra en diferentes presidios, o la están pasando gris como prófugos de la justicia pero encerrados dentro de su oscura conciencia; entre tales prójimos figuran muchos periodistas de oficio que en su momento compartieron grandezas y miserias junto al fundador y director de la revista Oiga y que, en mala hora, desoyeron las advertencias del maestro Igartua cuando este, visionario como pocos, les previno de mil formas sobre lo que le esperaba a este Perú cuando quedó sometido bajo una dictadura disfrazada de "democracia". Y entre tales "distinguidos" hombres de prensa están, seguramente, aquellos que a pesar de sus actos delictivos aún no son alcanzados por el largo brazo de la justicia, sino humana, divina, pero que deben estar viviendo enfermos de remordimiento, si es que todavía tienen algo de vergüenza, en primer lugar por no haber escuchado en su momento al director de Oiga cuando este les pidió ponerle el ojo al "presidente de ojitos rasgados" y no creer en sus cantos de sirena; en segundo lugar, lo que fue peor, por haber vendido la ética periodística y las líneas editoriales de sus medios a los intereses y designios del entonces mandatario de turno. Y estos "ilustres" colegas, a los que habría que agregar empresarios sin escrúpulos dedicados a esta actividad, y a peores directivos de diversos medios, fueron quienes convirtieron al periodismo peruano en una cloaca. Era un "statu quo" impuesto y soterrado, dirigido desde el Palacio de Gobierno de Lima y los fueros del SIN y las FFAA y policiales, con la "ayuda" de malos funcionarios de Economía y Finanzas, malos fiscales, peores jueces, y qué demás otras perlas, que hundió al Perú en la peor crisis moral de su historia, donde los villanos terminaron siendo héroes, y los héroes... se convirtieron en villanos.

Aquí, pues, la verdad, la gran verdad es que un 12 de julio de 1993, en medio de la agitación y violencia que se vivía en el país, la revista Oiga publicaba una denuncia periodística que tituló: Historia de una traición o el "Plan Verde". Fue un documento que marcó el inicio de una de las peores dictaduras de nuestra agitada vida 
republicana. Un acontecimiento desencadenante que estuvo enmarcado por las mentiras mediáticas del régimen, la inconsciencia de la opinión pública -sedada por una sutil manipulación sicosocial y otras artimañas $-\mathrm{y}$, sobre todo, por las reiteradas y sistemáticamente ignoradas denuncias sobre las violaciones contra los derechos humanos cometidas por el gobierno del "chino", entre estos el asesinato de comunidades enteras en las zonas convulsionadas por la guerra antisubversiva y la formación de "escuadrones de la muerte", como el tristemente célebre Grupo Colina.

El exterminio de lo que ellos denominaban excedente poblacional o excedentes poblacionales nocivos fue tal vez uno de los puntos más controvertidos del "Plan Verde". En un afán casi enfermizo por bajar las altísimas tasas de natalidad que se daban, y se dan todavía, en las regiones más pobres del país, el gobierno fujimorista cometió una serie de excesos que causaron más daño que beneficios. Para resolver el asunto demográfico se diseñaron diversas estrategias con el fin de cumplir lo que proponía el "Plan Verde". Tales "estrategias" se llevaron a cabo principalmente en las zonas alto andinas y en la llamada "montaña", es decir, la amazonia peruana. En dichos "programas" poblacionales se utilizó todo tipo de procedimientos. Uno de los más polémicos fue el caso de las esterilizaciones forzadas -mediante las ligaduras de trompas, por ejemplo- que se realizaron bajo engaños en incautas mujeres, principalmente campesinas de la sierra e indígenas del gran llano amazónico. Por allí se decía que el mandatario de turno pretendía acabar con las razas autóctonas, creencia que parece quedar corroborada en el contenido de este "plan" (Nota 16). No faltaban, por cierto, otras modalidades de exterminio (de gente indeseable) donde las víctimas eran también consideradas como excedentes poblacionales nocivos (prostitutas, enfermos de SIDA, enfermos mentales, homosexuales, drogadictos, delincuentes comunes, narcotraficantes, indigentes, terroristas, gente presa por diversos motivos, ancianos de asilos, etc.). 
En la lectura del texto de este "proyecto" de gobierno que les ofrecemos a continuación, el lector podrá comprobar también la constante reiteración de frases y palabras, como las arriba mencionadas, que hemos puesto cursiva para resaltarlas; se repiten constantemente a lo largo de todo el contexto como si ese fuera el objetivo principal del "Plan Verde": se trataba de una forma brutal de encarar los "problemas" de tipo social o demográfico, aunque, por desgracia, la solución, el remedio, fue peor que la enfermedad, y lo más grave es que no eran precisamente, ni necesariamente, "terroristas" o "delincuentes", los principales objetivos de tales prácticas o "estrategias" contra poblaciones excedentes y nocivas, ya sea por las aludidas razones o de otra índole. En otras palabras, el fin, para nada, justificaba los medios. Pero tales medios, nada recomendables, fueron utilizados. Así fue como pagaron justos por pecadores. Muchas personas que nada tenían que ver con este asunto, se vieron envueltas en la vorágine de la violencia y se convirtieron en víctimas de este macabro juego. La burda justificación esgrimida por algunos de los implicados en las violaciones de los derechos humanos, la afirmación de que aquello "era una guerra" y que tales muertes "sucedían en toda guerra", no exime, entonces, de responsabilidad, a los criminales de lesa humanidad; comandos armados como el Grupo Colina perpetraron sus matanzas a conciencia, y cuando lo hicieron no tuvieron contemplaciones: simplemente metieron a todos en el mismo saco. A los nueve estudiantes y al profesor de la Cantuta los arrebataron, que sino secuestraron, de su centro de estudios para asesinarlos sin motivo aparente. En el caso de Barrios Altos, los militares irrumpieron sin tocar la puerta en aquella quinta del jirón Huanta: entraron a matar. Era una "pollada" (es decir, una fiesta popular donde se degustan potajes a base de pollo. N. de VA), una alegre reunión vecinal donde había niños, mujeres y ancianos. Hacer daño sin mirar a quien: esa fue la tónica y la "estrategia". Esa fue la realidad. 
Por su parte, los deudos de las víctimas de aquellas acciones aleves, que les arrebataron a sus seres queridos, desde hace años están reclamando justicia y reparación por lo irreparable. Y mientras esto sucede, los seguidores del ex presidente se empeñan cínicamente en continuar negando la responsabilidad de Fujimori y su "mafia" y quieren seguir creyendo que su líder era "un gran presidente" y que bajo su régimen "el país estaba bien". A los familiares de los asesinados de La Cantuta y Barrios Altos, así como de los muertos en otras masacres colectivas "por razones de Estado" nada les podrá devolver la vida del hijo, del padre, de la madre, del hermano o de la esposa, asesinados. A pesar de que las evidencias de los crímenes de lesa humanidad, amén de los testimonios de testigos y protagonistas, eran demoledoras, aún quedan rezagos del "ninguneo" de hace trece años, que lo niega todo a capa y espada, tratando de "ignorar" la existencia del "Plan Verde" y, por ende, omitir el recuerdo de quien tal vez fuera el mayor opositor del fujimorismo, la figura de Francisco Igartua Rovira. Se trata entonces de una especie de conspiración de silencio que en los últimos años ha pretendido "borrar" de la memoria reciente aquella histórica denuncia de Oiga sobre la aplicación del "Plan Verde" en el devenir político peruano. En resumen, es una increíble amnesia colectiva que empieza por los medios de prensa, principales promotores de todo este "no sé nada" o "no me acuerdo de nada" o, dicho criollamente: "échale tierrita nomás". Hay periodistas conocidos que laboran en diarios como El Comercio o en emisoras grandes de TV como es el caso de Frecuencia Latina canal 2, o en revistas como Caretas, que, estamos seguros, conocen muy bien la trayectoria de la revista Oiga, pero se callan cada vez que se acerca un 24 de marzo, aniversario del fallecimiento de su director, o han reducido su recuerdo a un simple "hecho anecdótico". Sencillamente no quieren saber nada de él o reaccionan con evasivas cuando se les pregunta algo al respecto. Sin embargo, ellos saben muy bien quién fue Francisco Igartua y conocen muy bien de su lucha contra dictadores y corruptos, quienes temblaban ante su línea editorial basada en la dignidad humana, en la 
justicia social, en la ética profesional, en la decencia y los valores morales, en el respeto a las leyes, y en la objetividad periodística. Todavía hay prójimos que, en su ceguera pertinaz y en su obtusa perspectiva de la realidad, persisten en seguir creyendo ilusamente que "el chino fue un gran gobernante" y que la justicia peruana lo va a liberar para que vuelva a postular a la presidencia... en el 2011 (aunque esta posibilidad parece bien remota). Para muchos de ellos ni la revista Oiga ni su fundador, Francisco Igartua, existieron jamás, y que cuando alguien se acuerda de esto hay que callarlo o ignorarlo. Y el periodismo peruano, en una actitud claramente cómplice, parece creerse esta absurda postura y guarda silencio: "el que calla, otorga", eso dicen. Pero los hechos quedaron escritos en el libro de la vida...

\subsection{Evidencias que queman}

Nota: Reportaje publicado en la revista Oiga del 12 de julio de 1993, en el mismo número donde también se denunció la existencia del llamado "Plan Verde". (Nota 1)

Luego del hallazgo de cuatro fosas con restos de cadáveres calcinados -la noticia más importante de la semana que culminó ayer-, el curso de los acontecimientos en torno a este caso ha tomado un giro que desnuda el propósito oficialista de escamotear las investigaciones que conduzcan a la verdad: no sólo se dejó sin vigilancia el paraje de Cieneguilla (Nota 2) donde se encontraron dichas fosas y se hizo evidente la desidia del régimen por darle al tema la trascendencia que merece, sino que también la acción del Ministerio Público quedó en manos del fiscal Víctor Cuba Villanueva -por encontrarse de turno-, el mismo individuo que cuidó los intereses palaciegos negándose a investigar la denuncia de Susana Higuchi contra sus parientes políticos -señalados como traficantes de donaciones - (doña Susana era la entonces esposa de hoy ex presidente Alberto Fujimori y primera dama de la 
Nación. N. de R.) y la matanza de los Barrios Altos. Los rápidos reflejos de la dictadura, como en otras ocasiones, no se han dejado esperar.

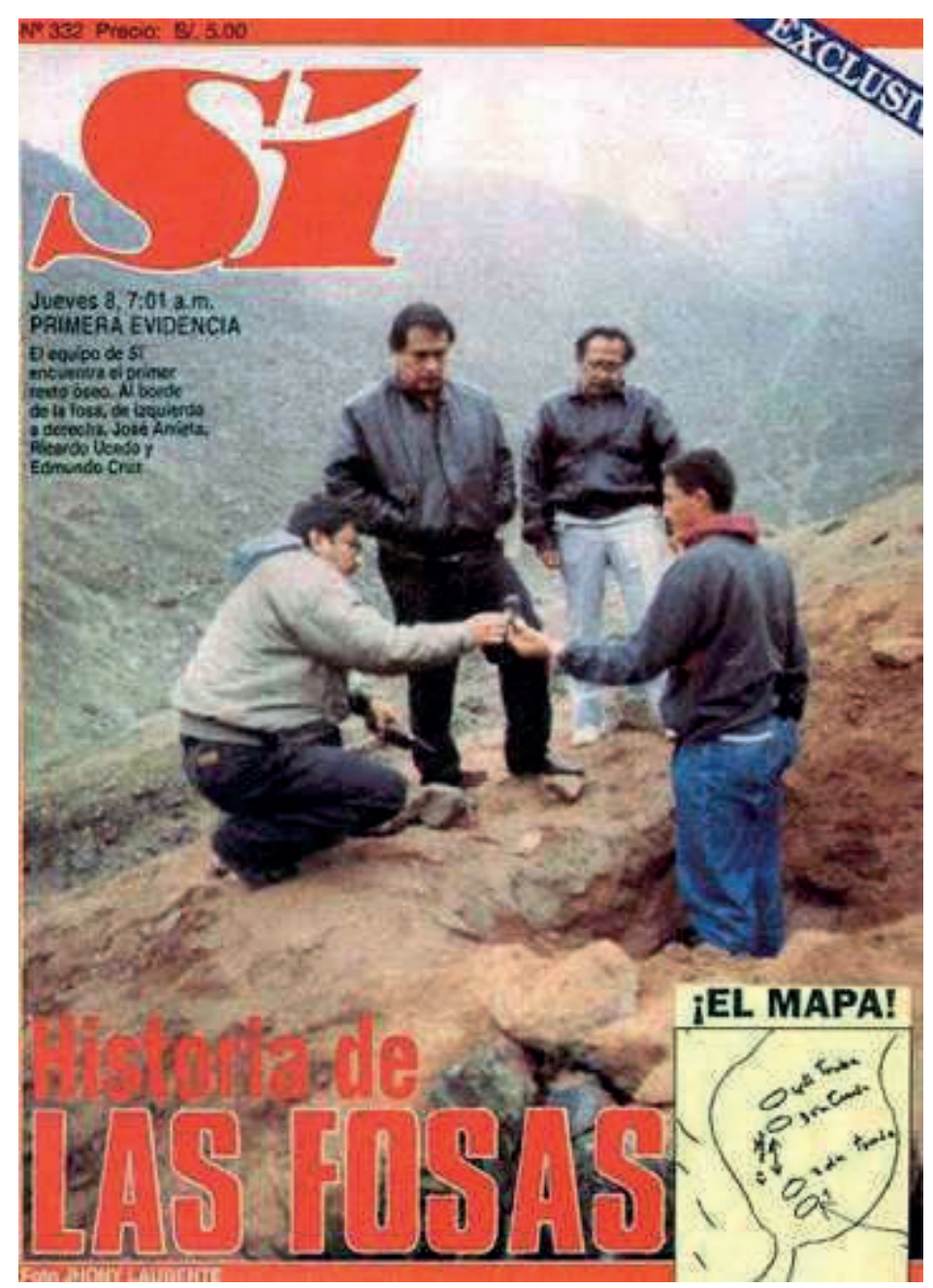

Figura 1a. El sí de la revista Sí. El mismo día en que Oiga publicara la denuncia sobre la aparición de personas asesinadas y enterradas en una fosa común de las afueras de Lima, y denunciara sobre la existencia del siniestro "Plan Verde", la desaparecida revista Sí se anotó un gol periodístico al revelar la ubicación de tales restos humanos. Foto del portal de Aprodeh.org.pe 


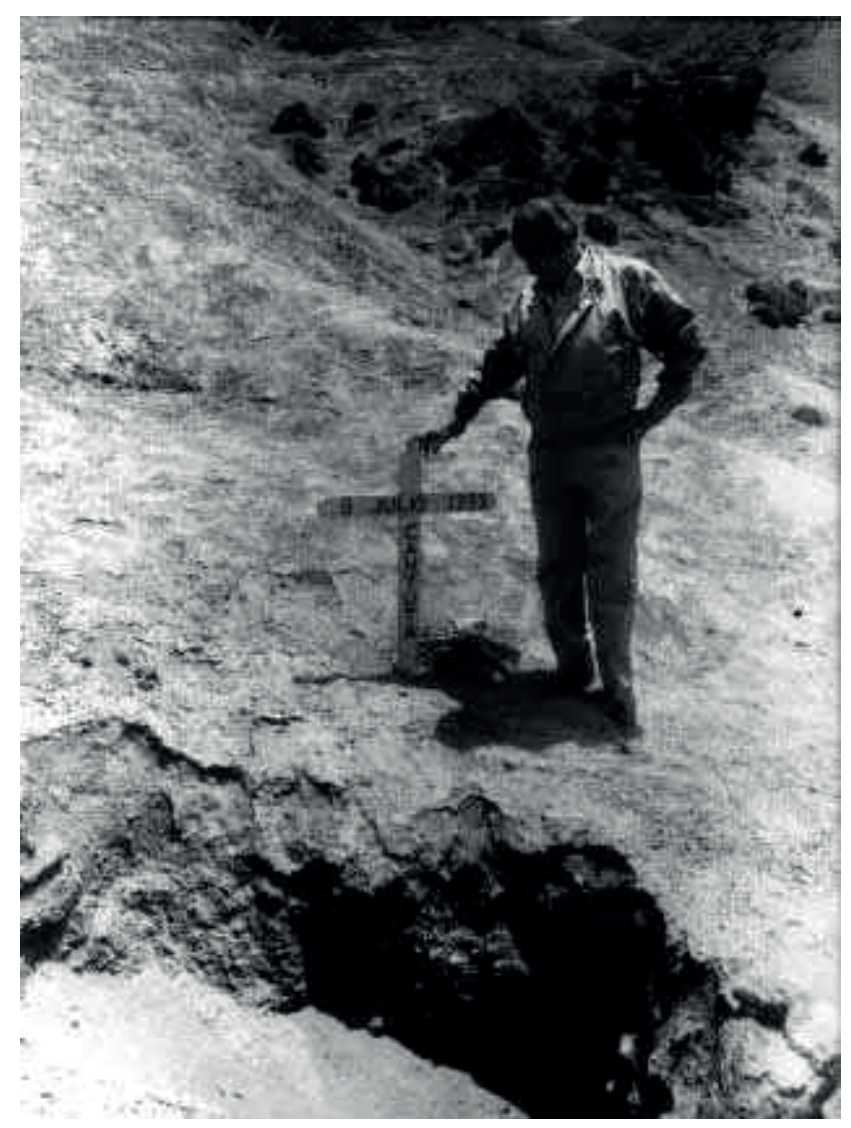

Figura 1b. En las fosas de Cieneguilla, donde fueron sepultados los universitarios de La Cantuta. Leyenda de foto de la revista Caretas en su artículo "En el lugar de los hechos", Lima, 25/1/1996.

Foto archivo Caretas.

Más, es notorio que cada vez se le hace más difícil al dictador mantener la aureola de quien se siente capaz de controlar todo. A lo largo de la semana pasada, este y otros sucesos demostraron que -como cualquier cholito caído del palto - Alberto Fujimori también acusa una serie de flancos débiles por donde transpiran gruesas gotas de inseguridad. Su imagen de omnipotente, infalible, glorioso e impune entra, por momentos, en una cuenta regresiva obligándolo a tomar precauciones que le sirven de sustento a los planes ya trazados.

Según León Dormido, el asunto de las fosas podría ser parte de un plan oficialista para tapar lo de la Cantuta. 
Ello se observó en los incidentes que Fujimori tuvo que enfrentar durante su gira por Cusco y Arequipa, lugares donde las protestas y hasta las rechiflas dieron marco a este periplo electorero y que - sin embargo - fueron absolutamente silenciadas por los noticieros de televisión. El motivo de esto último es muy simple: Ahora Palacio de Gobierno sólo convoca para los viajes presidenciales a los reporteros de los distintos canales, prescindiendo de los respectivos camarógrafos; quienes graban las giras son los camarógrafos oficiales que -luego de editar las partes que le convienen a Fujimori - distribuyen los casetes de video. Así quedan anuladas para la historia las manifestaciones de desaprobación contra el 'chino'... y quedan explicadas las declaraciones del propio Fujimori a la televisión brasileña, afirmando que tenía 'controlada' a la TV.

Estos malabares fujimoristas se inscriben dentro del accionar estratégico, coyuntural, de un gran designio que hasta la fecha sólo podía intuirse merced a un análisis concienzudo del estilo del presente gobierno. Las importantes revelaciones que OIGA formula en la presente edición, basadas en documentos elaborados por un 'equipo de trabajo' que formó el alto mando del Ejército junto al Servicio de Inteligencia Nacional antes de las elecciones de 1990, han de renovar la lupa política con que se evaluaba el desenvolvimiento gubernamental de Fujimori. Como si se tratara de una apelación bíblica, puede decirse que todo estaba escrito, incluso los pormenores de una filosofía de guerra sucia para combatir al terrorismo, cuyo saldo bien podría estar expresado -en parte - por los cadáveres hallados en Cieneguilla.

En Cieneguilla a las puertas de Lima, y no en zonas de combate ni en parajes desolados (Nota 3), han sido encontradas fosas con restos humanos calcinados. Lo más notable de este hallazgo no es la aterradora comprobación de un hecho reiteradamente denunciado por los organismos defensores de los derechos humanos, sino la indiferencia con que las autoridades han recibido la noticia no obstante que, 
desde el primer momento, se ha dicho que esos restos podrían pertenecer al profesor Hugo Muñoz Sánchez y a los nueve alumnos desaparecidos de La Cantuta la madrugada del 18 de julio de 1992 tras un operativo ejecutado por el Ejército en esa universidad magisterial.

Las cuatro fosas fueron encontradas el jueves en la quebrada de Chavilca, al lado de un camino que nace a la altura del kilómetro 14 de la carretera a Cieneguilla, por periodistas de la revista SÍ, que siguieron el derrotero en un plano entregado por manos anónimas.

El primer día estuvieron presentes tres fiscales, dos médicos legistas, representantes de organismos defensores de los derechos humanos -entre ellos Peter Archard, representante para América Latina de Amnistía Internacional quien, coincidentemente había llegado a Lima días antes-, miembros de la Comisión de Derechos Humanos del CCD -es decir, el ilegal Congreso Constituyente Democrático que se inventó Fujimori cuando en 1992 se tumbó al sistema democracia peruana con su "autogolpe" del 5 de abril de ese año. N. de R - , encabezados por Roger Cáceres y una nube de reporteros de todos los medios informativos del país, amén de algunos corresponsales de la prensa extranjera.

El jueves, entre el mediodía y las cinco y media de la tarde fueron removidas tres de las cuatro fosas, con más entusiasmo que pericia, y se encontraron huesos quemados por el fuego, restos de prendas de vestir y un llavero conteniendo algunas llaves y algo que parecía ser una placa o medallón. Todo fue metido en bolsas y entregadas a los médicos legistas para las pericias correspondientes. Las tumbas quedaron abandonadas a su suerte. 


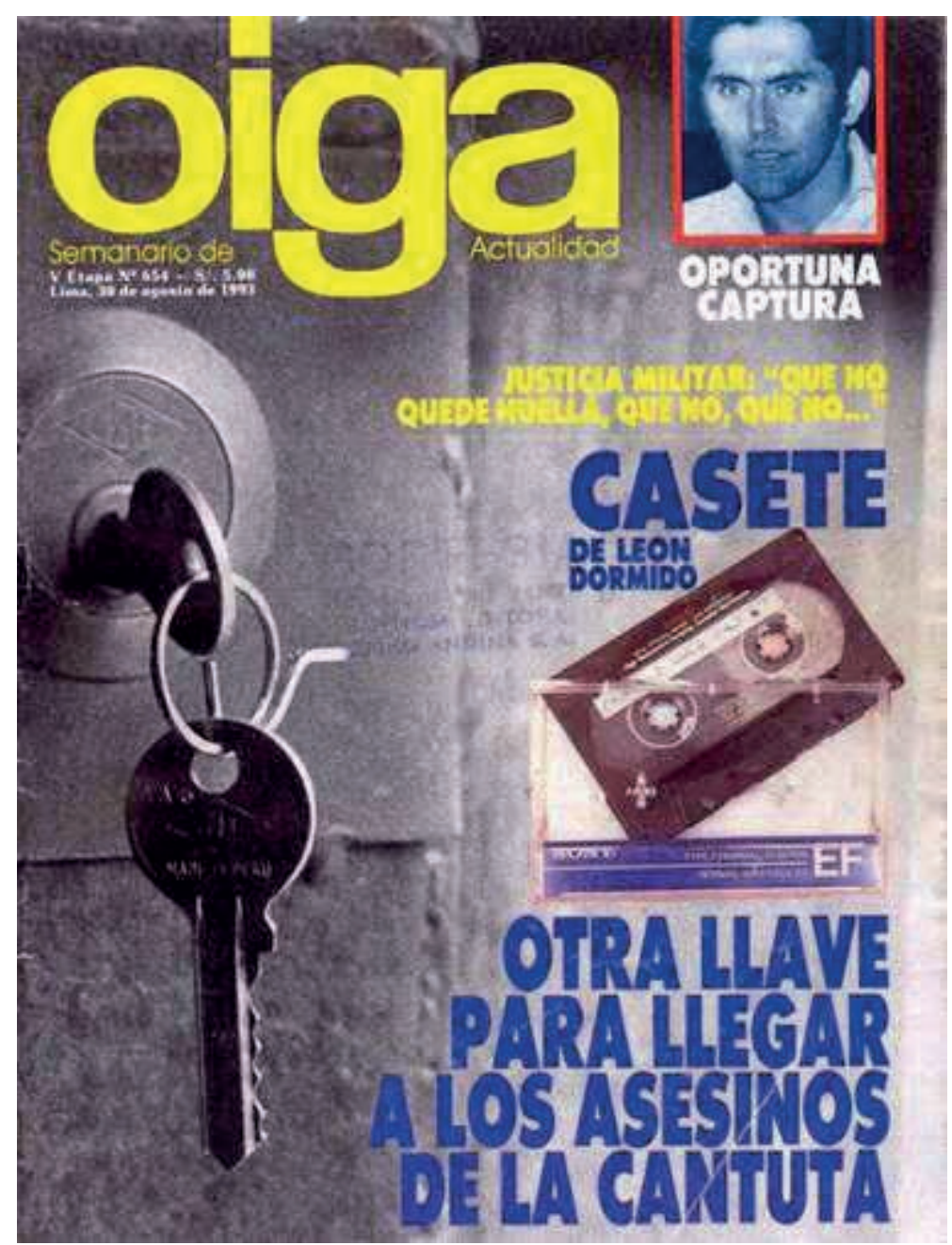

Figura 2. Llaves. Oiga, en su edición del 30 de agosto de 1993, siguió publicando demoledoras evidencias sobre los crímenes de lesa humanidad que estaba cometiendo el ilegal "Grupo Colina" con el aval presidencial. El llavero sirvió para confirmar que tales restos eran, efectivamente, los del profesor y los nueve alumnos de La Cantuta desaparecidos el 18 de julio de 1992.

Foto del portal Aprodeh.org.pe 


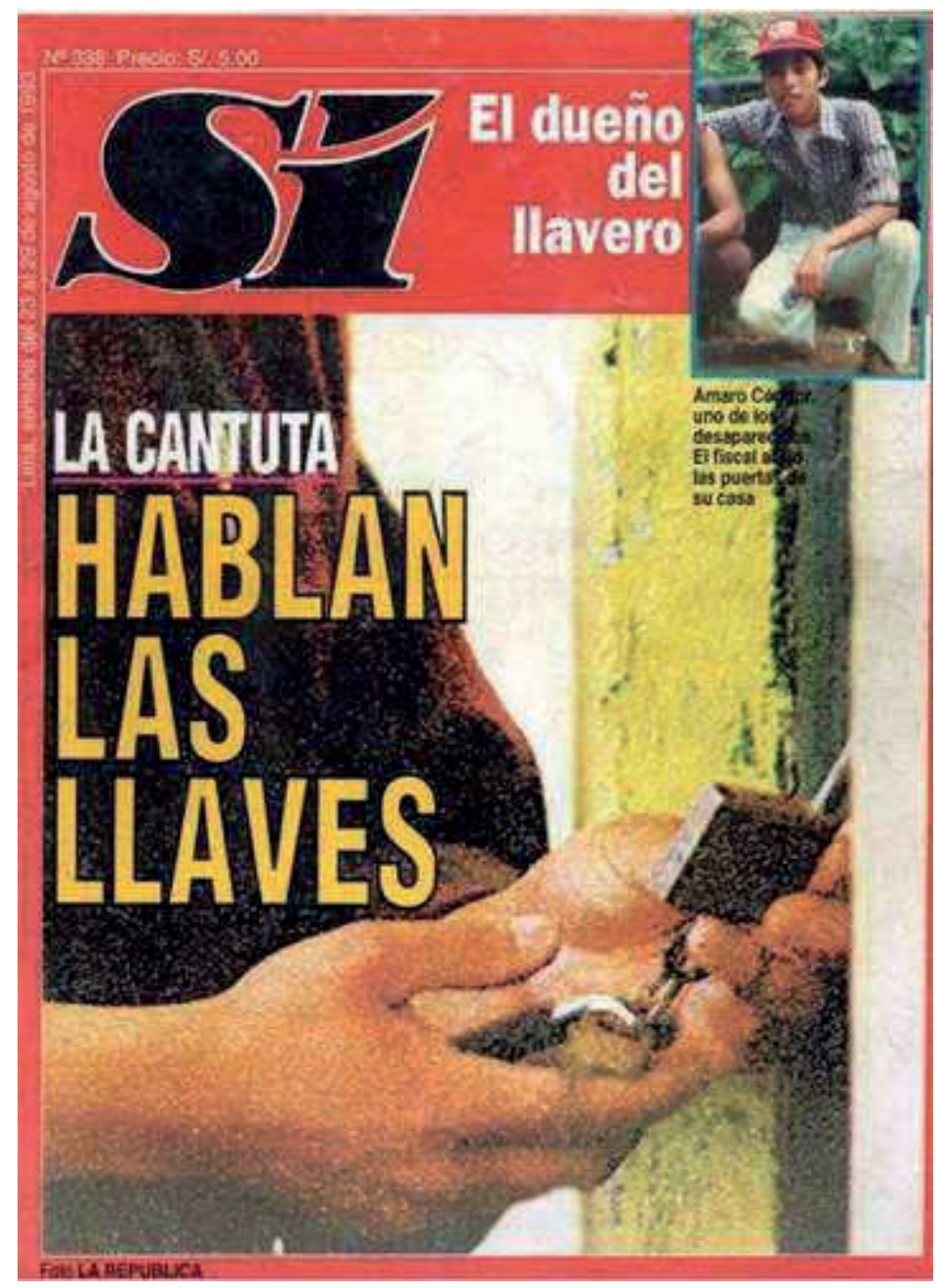

Figura 3. La revista Sí, por su parte, logró identificar al dueño de aquellas llaves que los asesinos de los estudiantes y el profesor de la Cantuta no se tomaron el trabajo de desaparecer. Una evidencia más de la saña y la crueldad con la que actuaron los criminales que, por lo que se ve, no repararon en nada.

Foto de portal Aprodeh.org.pe

El viernes, cuando se esperaba la reanudación de los trabajos de excavación y búsqueda de nuevas fosas, no apareció ninguna autoridad. El doctor Víctor Cuba Villanueva, uno de los fiscales que estuvieron en Cieneguilla el jueves, habría dicho que las excavaciones habían sido suspendidas al no haber indicios sobre la existencia de otras tumbas. ¡Qué curioso!, el doctor Cuba es el mismo fiscal que intervino en la 
matanza de Barrios Altos y no descubrió nada; también es el mismo que 'investigó' la denuncia de doña Susana Higuchi contra sus cuñados, a quienes acusó de aprovecharse de las donaciones extranjeras, y tampoco encontró nada doloso. El doctor Cuba es el fiscal ad hoc por excelencia; uno de los pocos que sobrevivió a la razzia de fiscales y magistrados ejecutada por Fujimori tras el golpe del 5 de abril del 92.

Mientras las fosas y lo que pudieran contener quedaban abandonadas a su suerte y el locuaz ingeniero Fujimori guardaba hermético silencio negándose a comentar el descubrimiento, desde Tarapoto el comandante general del Ejército, general Nicolás Hermoza Ríos, declaraba que los 'organismos jurisdiccionales competentes' debían investigar a fondo "para que saquen sus conclusiones y determinen lo que es conveniente". Hermoza se remitía a la justicia castrense que ha hecho cuestión de estado la exclusividad en la investigación de los desaparecidos de La Cantuta.

Todo demostraba que no había ningún interés por parte del gobierno en disponer una investigación seria alrededor de los restos encontrados en las fosas. El viernes, Peter Archard, de Amnistía Internacional, pidió a la fiscal de la Nación, Blanca Nélida Colán, la instalación de una guardia judicial civil las 24 horas del día para mantener la seguridad del lugar, a la espera de la llegada de expertos en antropología y arqueología forense de reconocimiento internacional. Cuando Alfredo Barnechea, desde su programa 'En Directo', difundido el jueves por el canal 9 le sugirió al doctor Jaime Freundt, de la mayoría fujimorista en el CCD, la posibilidad de llamar a especialistas extranjeros, éste respondió con la siguiente pachotada: "yo no creo que haya necesidad aquí de alborotar al cotarro trayendo argentinos, americanos o chinos a que investiguen una cosa que es un problema nacional y que debe ser, por lo tanto, resuelto por peruanos". 
¿Qué drama encierran las fosas de Cieneguilla? ¿Están allí los restos de los 10 desaparecidos de la Cantuta? Por lo menos los anónimos informantes de SÍ sostienen esa versión. (Nota 4) Y desde Buenos Aires, el general Rodolfo Robles, quien tuvo que exiliarse tras denunciar la existencia de un escuadrón de la muerte conformado por agentes del SIE (Nota 5) que en su haber tenía el secuestro, asesinato y desaparición del profesor y nueve estudiantes de La Cantuta, dijo a El Comercio que el hallazgo de las fosas "debería obligar al gobierno a investigar y decir toda la verdad referente a las desaparición es de los universitarios". Robles añadió que las fosas de Cieneguilla confirmarían las versiones que le brindó personal de su confianza antes de abandonar el país, según la cual los cuerpos de los estudiantes y del profesor de La Cantuta habían sido calcinados justamente "para que si algún día se llegaba a detectar los cuerpos iba a ser difícil identificarlos".

En este punto hay coincidencias con informes proporcionados por León Dormido, una logia de oficiales en actividad dedicada a informar sobre las violaciones a los derechos humanos cometidos por personal militar. En uno de sus boletines, que no publicamos porque la versión nos parecía increíble, León Dormido mencionaba que durante los días 21, 22 y 23 de abril, tras el 'tancazo' del general Hermoza, el mayor Santiago Martín Rivas, uno de los oficiales mencionados por el general Robles como integrante del 'escuadrón de la muerte' del SIE, y su equipo, con el que intervino en La Cantuta, se dirigieron al centro recreacional de verano del Ejército, conocido como Playa La Tiza, ubicada a la altura del kilómetro 56 de la Panamericana Sur, y procedieron a desenterrar los cadáveres que se encontraban en ese lugar desde el 19 de julio del año pasado. Después de victimarlos la misma madrugada del 18 de julio, esos cadáveres fueron enterrados en un paraje de Huachipa; luego desenterrados para ser vueltos a enterrar en la Playa La Tiza. Finalmente, los restos fueron desintegrados empleando una serie de compuestos químicos. Esta versión de León 
Dormido no dice qué hicieron después con los despojos. ¿Acaso fueron vueltos a enterrar, esta vez en Cieneguilla?

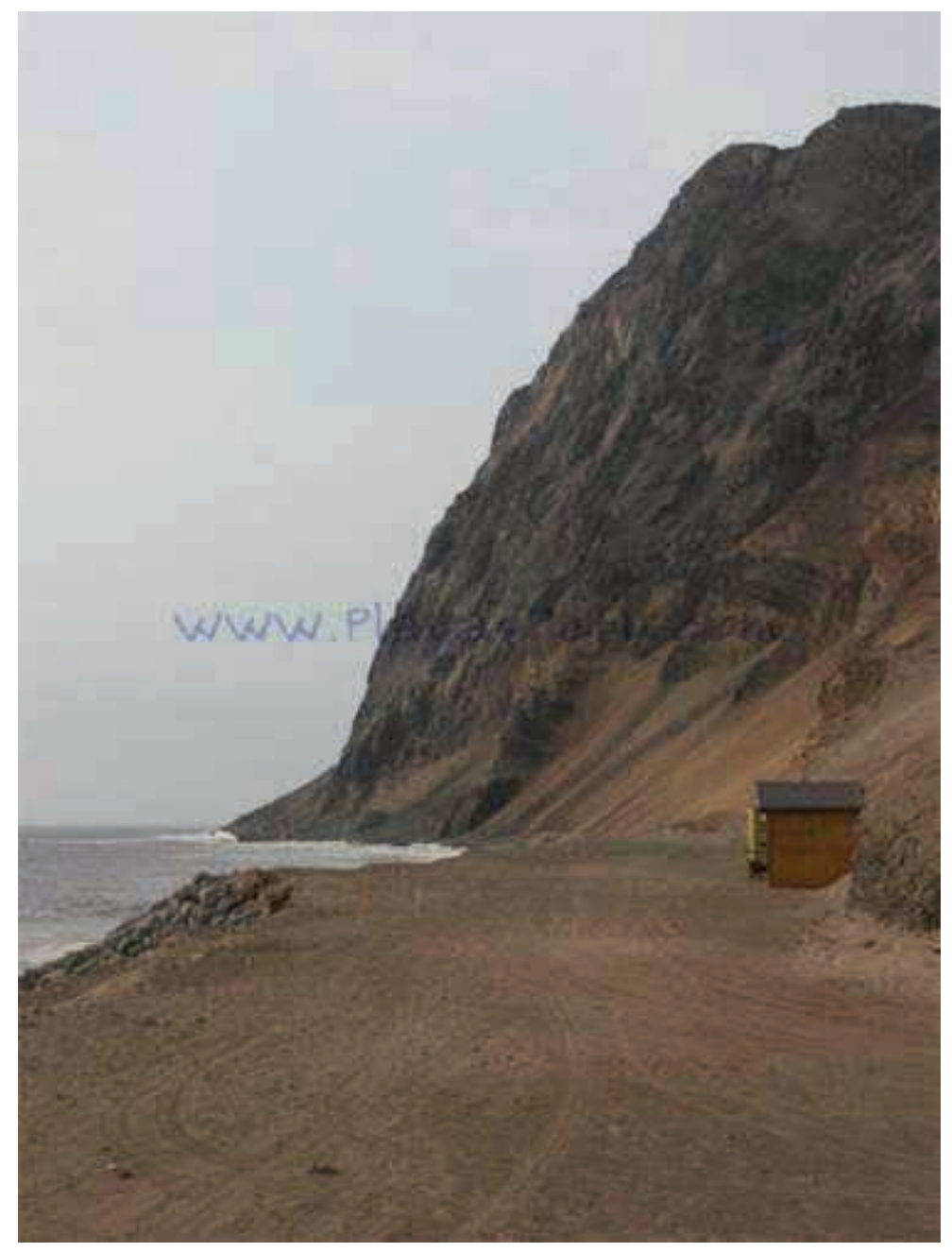

Figura 6. Ahora la famosa playa La Tiza, al sur de Lima, se ha convertido en un balneario privado para gente rica; qué lejos están sus habitantes de sospechar siquiera la sangrienta historia que se tejió en sus arenas; en este lugar el Grupo Colina ensayó la matanza de Barrios Altos y luego habría enterrado allí los cuerpos de los nueve estudiantes y el profesor de La Cantuta asesinados, antes de llevarlos a una fosa común en Cieneguilla.

Foto del blog turístico playasperu.com 
El viernes, una persona que se identificó solamente como vocero de León Dormido nos llamó por teléfono y nos dijo que si los que le dieron a la revista Sí el derrotero para hallar las fosas de Cieneguilla y afirman que allí están los restos de los desaparecidos de La Cantuta, son los mismos que entregaron el documento que esa revista publicó en su edición del 19 de abril, entonces hay que tomar como cierta esa versión. Nos dijo que León Dormido confirmó la autenticidad de ese documento una ayuda memoria de una dependencia del Ejército - en el que se hacía referencia a la presencia de Sendero Luminoso en La Cantuta y su vinculación con algunos profesores y estudiantes, entre los cuales se encontraban los que desaparecieron la madrugada del 18 de julio.

Pero el anónimo vocero de León Dormido también nos hizo una advertencia: hay que manejar el asunto con pinzas porque igualmente podría tratarse de un plan diabólicamente concebido -acaso por la mente del psiquiatra Segisfredo Luza? (que se hizo famoso por haber asesinado a uno de sus pacientes por creerlo un "monstruo". Nota de VA) - para terminar con el caso de los desaparecidos de La Cantuta con una operación que deje limpios a sus ejecutores y al gobierno. Según León dormido, el plan sería el siguiente:

Que los periodistas descubran las fosas con restos humanos, los que serán identificados como pertenecientes a los desaparecidos de La Cantuta. El llavero es pieza clave para que no queden dudas.

Posteriormente captura de un grupo de supuestos terroristas de Sendero Luminoso -no más de cuatro personas - confesando que efectivamente secuestraron al profesor y a los estudiantes y los 'ajusticiaron' porque habían traicionado 'la causa revolucionaria'.

Juicio secreto en un tribunal militar que los condenaría a cadena perpetúa. 
Salida de los falsos terroristas a un país extranjero, con identidad cambiada, a donde irían a residir con sus familiares, los que saldrían sigilosamente.

Así quedaría cerrado el caso que hoy le quema a la justicia militar, que no sabe cómo salir del atolladero, sobre todo porque el general Hermoza admitió ante el juez civil que efectivamente la madrugada del 18 de julio de 1992 elementos del Ejército hicieron un operativo de rastrillaje en La Cantuta. La cúpula militar saldría bien librada y Fujimori y su jauría periodística tendría motivo para fustigar a la prensa de oposición que nunca aceptó la versión oficialista de que los estudiantes y su profesor 'se autodesaparecieron' (sic. N. de VA) para sumarse a las huestes terroristas.

El plan parece demasiado fantástico, pero hay elementos que deben ser tomados en cuenta: a) que los juicios a los terroristas son, por lo general, secretos; b) que los condenados a cadena perpetua no reciben visitas durante un año y nadie sabe dónde están purgando condena (caso de los 'abogados democráticos' Alfredo Crespo y Jorge Cartagena) y, c) que hay por lo menos un antecedente aunque bajo circunstancias distintas. Ahí están el caso del comandante de Marina Artaza, el célebre 'comandante Camión' acusado de una matanza en Ayacucho, desaparecido misteriosamente cuando la justicia civil lo reclamaba insistentemente. En la Marina se sabe que Artaza está en algún lugar del mundo, con toda su familia.

\section{El "Pajarillo verde" que nadie hizo caso... -salvo Oiga - o la historia de una traición ignorada contra el pueblo peruano}

\section{(...)}

En los lineamientos del plan, trazados en octubre de 1989, y en Anexos posteriores a esa fecha, están insertos los planeamientos que, como grandes novedades, viene, repitiendo Fujimori: Libre comercio, "reinsertación", pena de muerte, pacificación, 
reforma educativa, acuerdo en las fronteras (entendiendo que "el aspecto territorial ha sido ya rebasado"), necesaria continuidad en el mando (reelección), etc. Pero hay puntualizaciones muy reveladoras del nefasto mesianismo que inspira al proyecto en general, hasta ahora mantenido en el mismo misterio, y que apenas se dejan entrever en algunas de las bruscas declaraciones de Fujimori; como cuando, por ejemplo, se ufana de tener el mejor Servicio de Inteligencia de América Latina. En los textos conspirativos se da, justamente, mayor importancia a lo que llaman "Sistema de Control, Seguridad y Propaganda" y que en esas mismas páginas se especifica que "si, definitivamente, el Sistema es el equivalente a una Gestapo". El carácter antidemocrático del proyecto aparece por todos lados. Desde la "relación" que se seguirá con la prensa ("El objetivo mínimo consiste en conseguir la autocensura, dejando entrever nuestra decisión de ir hasta las últimas consecuencias"), hasta el modelo secreto del gobierno a montarse, muy explicativo de por qué en el régimen fujimorista tiene tan poca importancia el Consejo de Ministros. (...)

Editorial: Dos hechos que nos estremecen de Espanto. Revista Oiga, 12 de julio de 1993 (Nota 25)

Como verá el amable lector, este reportaje comienza después de la presentación, a modo de introducción, de uno de los más agudos análisis editoriales publicados por la revista Oiga a lo largo de su historia, donde su autor, Francisco Igartua, comienza hablando del descubrimiento de las fosas con los restos humanos de nueve estudiantes y un profesor desaparecidos de la Universidad Tomás y Valle de La Cantuta, en un paraje desolado cercano al distrito limeño de Cieneguilla. Este fue un hecho que no sólo provocó la primera gran crisis política del entonces gobierno de turno sino que, también, fue, como señala el autor de estas líneas, la confirmación de la existencia del tantas veces mentado "plan de gobierno", cuyos detalles siguen a continuación de estas valientes palabras del entonces Director de Oiga. 


\subsection{Editorial: Dos hechos que nos estremecen de espanto}

Artículo publicado por Francisco Igartua en Oiga, 12 de julio de 1993 (Nota 6)

Dos sucesos casi simultáneos, uno ya conocido por la opinión pública y el otro divulgado hoy en esta edición de OIGA, nos muestran el lado oscuro, el lado que se quiere mantener oculto, del régimen autoritario, con barniz democrático, que gobierna al país. Me refiero al descubrimiento de fosas clandestinas, con restos humanos calcinados, logrado por la revista SI, y a las revelaciones que, sobre la probable estructura real del actual régimen, puso en manos de OIGA un pajarito verde.

Esas tumbas de Cieneguilla, malolientes, escondidas a la vera de un camino de basura transitado por la miseria, pueda que no haya guardado los restos de los desaparecidos de La Cantuta, tal como lo creen muchos y lo propaga el rumor general. Pero allí si se escondieron huesos humanos calcinados y es posible que en esos muladares reposen otros muchos crímenes, de aquellos que sería demasiado difícil imputárselos al hampa y bastante improbable que sean obra de los terroristas los más crueles genocidas de nuestra no tan amable historia patria-, por estar ubicada allí, muy cerca, una base militar de vigilancia. Esos huesos humanos calcinados, con un llavero de recuerdo entre ellos y el increíble desinterés de las autoridades gubernamentales por custodiar las tumbas, son testimonio de los tiempos que nos ha tocado vivir. Pueden ser cadáveres de senderistas quemados por sus propios compañeros para que nadie los pueda identificar, puede ser cierto el rumor de que serian restos de los desaparecidos de La Cantuta. O de otros desaparecidos, añado, pensando en los textos que hoy publica OIGA, preparados por un secreto "Equipo de Trabajo" y por el Servicio de Inteligencia, para un 
pronunciamiento militar que debió producirse en 1990, que se inicio el 28 de julio de ese año y se consolido con el golpe militar del 5 de abril de 1992.

Se trata de dos hechos secretos, secretísimos, y que, por lo tanto, no dejan huella evidente. No tienen firmas ni sellos. No hay declaratorias de defunción. Tampoco existen pruebas testimoniales comprobables. Hay, en un caso, el dato preciso, con mapa, de un anónimo elemento de Contrainteligencia o de la propia Inteligencia que ha querido liberar su conciencia o enredar los hechos. Pero los muertos están, son ciertos, son huellas de métodos que horrorizan, que hace se nos escarapele la piel y conducen al otro caso, a los documentos publicados hoy en esta revista, en el que las pruebas no están en firmas y sellos sino en la credibilidad, en la seriedad del pajarillo verde que deposito los textos en mis manos y en que esos textos casan, calzan, se machihembran a la perfección con los hechos públicos y semipúblicos que van ocurriendo al mismo tiempo de lo escrito. Cada comentario tiene su correspondiente comprobación en un suceso notorio. Bueno, no todos, como, por ejemplo, el juicio escrito sobre la necesidad de exterminar al "excedente poblacional nocivo, irrecuperable, como son los terroristas, vendedores de pasta básica, agitadores y demás traidores a la patria".

Se trata de documentos que revelan el carácter del régimen que preparaba, desde mediados de 1989, una logia militar con orden del Comando. Régimen que, a último momento, fue negociado con el presidente electo, Alberto Fujimori, porque este venia a resultar el más aparente cabecilla para la "Democracia Dirigida, civil-militar" diseñada en los círculos castrenses.

En los textos se hallan opiniones absolutamente ciertas sobre la realidad peruana mas que certeras en el análisis de la responsabilidad de Alan García - y es imposible quitarles la razón a muchos de los argumentos allí expuestos sobre la difícil 
gobernabilidad del Perú y la necesidad de contar con metas estratégicas nacionales de largo plazo. Se puede decir que a su lectura brotan verdades de a puño, aunque la mayoría de estos puñetazos sean más del agrado de la sensibilidad política de las llamadas derechas, que de otros sectores con mayores inquietudes sociales y populares. Hay, sin embargo, aspectos siniestros que a ningún demócrata, a ninguna persona con cierto refinamiento humano, pueda dejar de espantar. Se trata de un proyecto mesiánico, de orientación totalitaria, que nada tiene de democrático por más título de "Democracia Dirigida" que se haya puesto.

En los lineamientos del plan, trazados en octubre de 1989, y en Anexos posteriores a esa fecha, están insertos los planeamientos que, como grandes novedades, viene, repitiendo Fujimori: Libre comercio, "reinsertación", pena de muerte, pacificación, reforma educativa, acuerdo en las fronteras (entendiendo que "el aspecto territorial ha sido ya rebasado"), necesaria continuidad en el mando (reelección), etc. Pero hay puntualizaciones muy reveladoras del nefasto mesianismo que inspira al proyecto en general, hasta ahora mantenido en el mismo misterio, y que apenas se dejan entrever en algunas de las bruscas declaraciones de Fujimori; como cuando, por ejemplo, se ufana de tener el mejor Servicio de Inteligencia de América Latina. En los textos conspirativos se da, justamente, mayor importancia a lo que llaman "Sistema de Control, Seguridad y Propaganda" y que en esas mismas páginas se especifica que "si, definitivamente, el Sistema es el equivalente a una Gestapo". El carácter antidemocrático del proyecto aparece por todos lados. Desde la "relación" que se seguirá con la prensa ("El objetivo mínimo consiste en conseguir la autocensura, dejando entrever nuestra decisión de ir hasta las últimas consecuencias"), hasta el modelo secreto del gobierno a montarse, muy explicativo de por qué en el régimen fujimorista tiene tan poca importancia el Consejo de Ministros. En el esquema del proyecto esta explicado que la conducción de la política estratégica nacional a largo plazo corresponde a un "Consejo Estratégico de Estado" (CEE), "delegando el 
protagonismo, los aspectos diplomáticos y sociales y los problemas de corto plazo a los distintos encargados de los portafolios ministeriales". El CEE sera un misterio y no tendrá por que asistir a los Consejos de Ministros, "quedando con las manos libres, fuera del ángulo visual del enemigo, para impulsar al país y hacer frente a las necesidades de la guerra". El servicio de cámaras ya instalado, en la época de Alan García, en la Sala del Consejo de Ministros, le servirá al CEE para seguir de cerca por video las sesiones que crea necesario supervisar. Y siguen las perlas. Todas con desagradables evocaciones de equívocos salvadores de sus patrias, de trágicos devaneos autoritarios. De desastres que tuvieron auroras deslumbrantes.

¿Está funcionando el actual régimen bajo el esquema trazado en los documentos que hoy comienza a publicar OIGA?... Por desgracia hay demasiados indicios de que es así. Pobre Perú! Vamos de mal para peor, porque nunca, por ciertos y grandes que sean los males que es necesario superar, han sido buenas las soluciones mesiánicas, totalitarias, autocráticas. Siempre, a la corta o a la larga, las lágrimas borraran los aciertos que pudiera haber tenido el despotismo. 


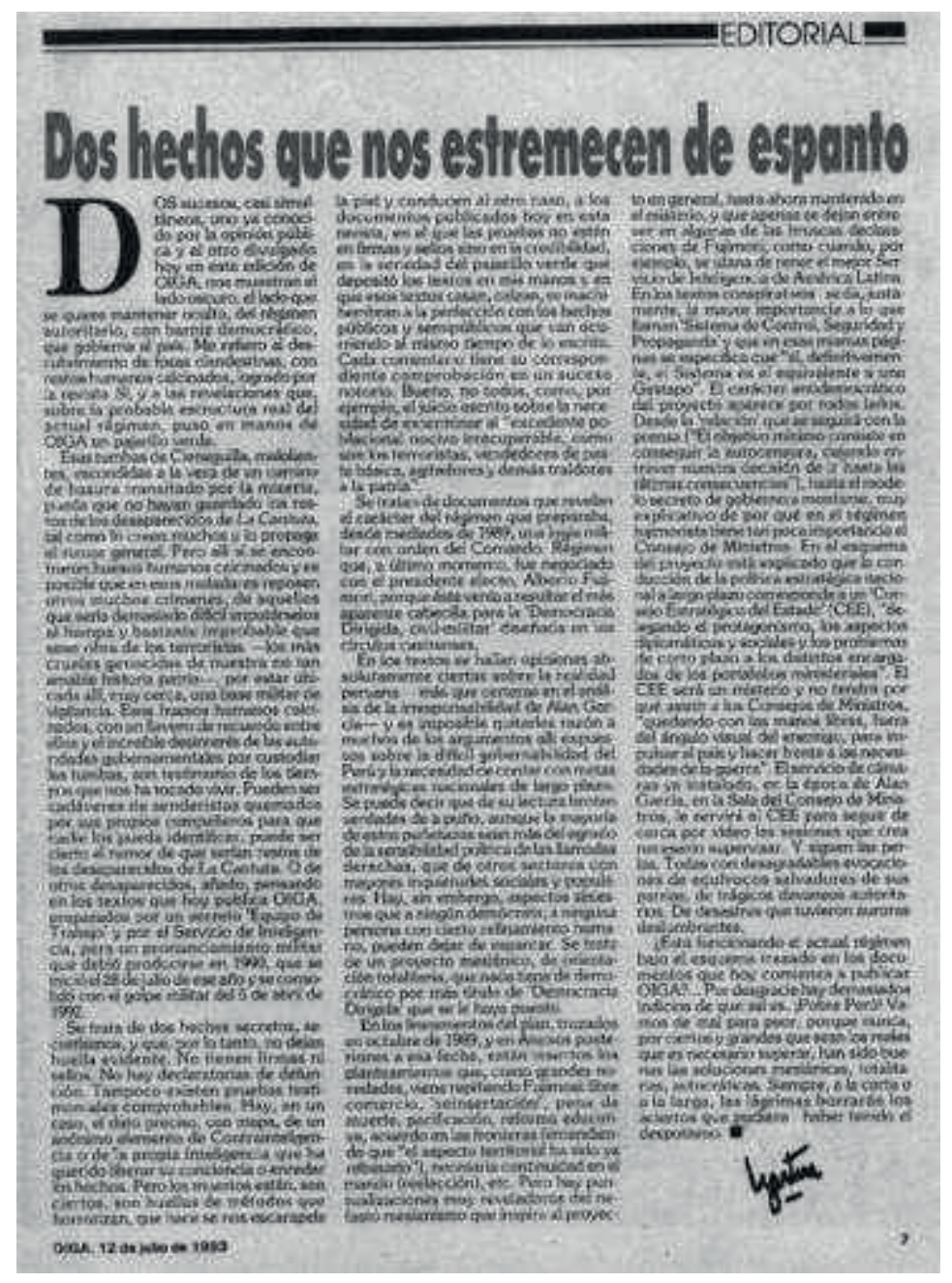

Figura 7. Facsímil de la página 7 de la revista Oiga en su edición del 12 de julio de 1993, con el texto de la editorial Dos hechos que nos estremecen de espanto.

Reproducción del sitio stucchi.tripod.com

\subsection{Preámbulo}

Para muchos fue una gran sorpresa la aparición de los carros armados en las calles de Lima el 5 de abril de 1992, mientras el presidente constitucional, Alberto Fujimori, anunciaba por televisión y radio la clausura del Parlamento y del Poder Judicial, el control de las comunicaciones y la prensa, etcétera. Solo unos pocos, entre ellos OIGA, venían observando que el régimen perseguía este desenlace desde tiempo 
atrás y en estas páginas hasta nos adelantamos a la noticia oficial del golpe militar. Sin embargo, nadie -fuera de los círculos castrenses- sospechó que el pronunciamiento militar del 5 de abril tenía un inicio muy lejano: octubre de 1989, cuando el señor Fujimori no había siquiera aparecido en el panorama político nacional. En esa lejana fecha, un 'equipo de trabajo' cumpliendo el "misionamiento (sic) ordenado por el comando" culminaba su tarea con un documento que así explicaba los objetivos revolucionarios en la introducción. Francisco Igartua. Texto previo al reportaje sobre "El Plan Verde" (Oiga, 12/7/93) (Nota 7)

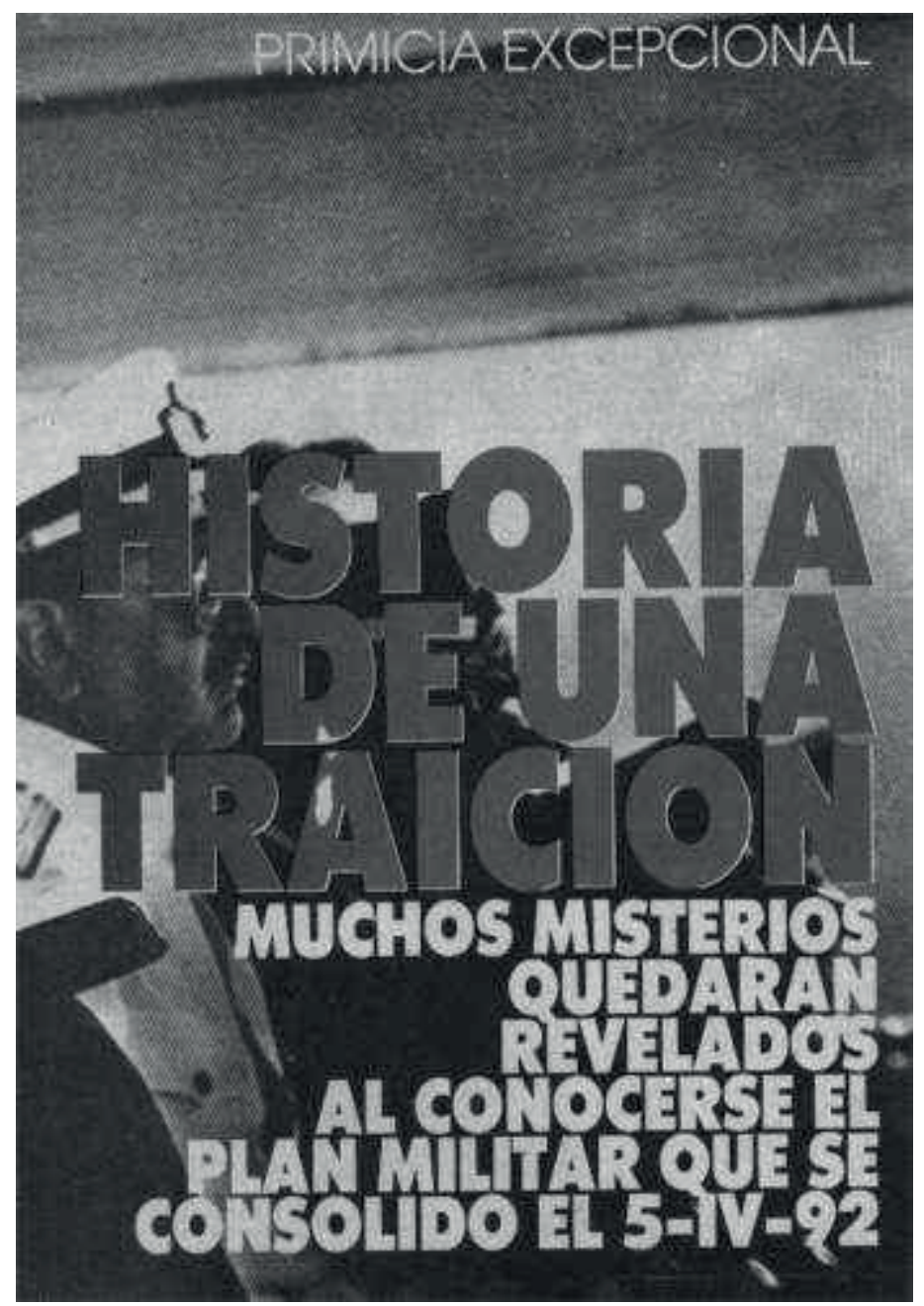

Figura 8. Facsímil de la página titular del reportaje Historia de una traición. Ilustración obtenida del sitio stucchi.tripod.com 
Bajo estas líneas encontrará el lector la descripción de un contexto que, si bien ya es parte de la historia reciente del Perú, se refiere a aspectos desconocidos que pintan de cuerpo entero el tinglado 'cívico-militar' que dio forma a uno de los regímenes políticos más corruptos, crueles e inhumanos que se han visto en la historia de Latinoamérica. Los diez años del gobierno fujimorista (1990-2000) fueron el marco perfecto para el desarrollo y la aplicación de los lineamientos de un "proyecto nacional" o "Plan de Gobierno" que, como ya anotamos, fue ocultado deliberadamente a la opinión pública peruana e internacional hasta mucho después de la subida de Alberto Fujimori al poder en 1990 -era pues un "plan" que seguramente hubiera continuado como "top secret" durante mucho más tiempo de no haber sido por el valiente pajarillo verde (Nota 8) que lo hizo llegar a Oiga en julio de 1993 - . Se trató, en definitiva, de un "proyecto" que, como denunciaba Francisco Igartua, ya estaba siendo secretamente aplicado cuando se cometieron los asesinatos de Barrios Altos y La Cantuta, siendo tales crímenes uno de los objetivos de Estado de tal 'plan'. La publicación en la revista Oiga del llamado "Plan Verde" corroboró lo que algunos sospecharon en su tiempo pero se callaron la boca, y demostró, una vez más, que nada se podía ocultar para siempre a los ojos de Dios y de los hombres, y que, tarde o temprano, la vergüenza de la historia acabará por cubrir a un régimen despótico y a un gobernante sin escrúpulos que acabó por pudrir hasta el último grano de la dignidad nacional de todo un colectivo, matando valores morales y cristianos, demoliendo la institucionalidad, destruyendo la esperanza y corroyendo el sentido común de lo que se supone es o debió ser un país con decencia. Se trataba de un documento que hasta ahora muy pocos peruanos conocen, y que muy poca gente en todo el mundo ha tomado conocimiento de él; es un texto cuya existencia fue y aún es "ignorada" de forma por lo demás sospechosa, pero cuya existencia fue y es real. Y ahora lo ponemos en sus manos, querido lector, como ya Oiga lo hizo en 1993, para que usted sea el juez y el crítico a la vez. La historia dirá, entonces, que un medio de comunicación, una revista peruana fundada por un gran periodista, tuvo la 
osadía de enfrentarse al poder y al sistema establecido con la verdad y la democracia como armas. La historia dirá también que aquella revista dio a conocer los malos propósitos de los peores gobernantes. Por ello, reiteramos aquí que Oiga tuvo que cerrar no solo por el acoso tributario de la Sunat o por haberse opuesto a la dictadura o a la violación de los derechos civiles, sino también, y por encima de todo, por haberse atrevido a denunciar la existencia a espaldas del Perú de este plan maligno; y lo que es más triste, tuvo que cerrar por haber advertido al pueblo peruano sobre la amenaza totalitaria que sobre él se cernía, cual negro nubarrón, mientras la sociedad andaba ciega, sorda y muda, viviendo en el limbo que había inventado el dictador de ojos rasgados. Nadie le hizo caso y después tal "ignorancia" terminaría por pasar factura. Estamos hablando, claro está, del 12 de julio de 1993, fecha de la publicación original de la primera parte de este documento, cuya segunda parte apareció en la siguiente edición de Oiga, la del 19 de julio de aquel mismo año.

\subsection{El "Plan" que trajo un pajarillo verde... $1^{\text {a }}$ Parte}

\subsubsection{Historia de una traición: Muchos misterios quedarán desvelados al conocerse el plan militar que se consolidó el 5-IV-92}

(Reportaje publicado en la revista Oiga, el 12 de julio de 1993) (Nota 9)

Nota de Redacción: Previo a la presentación de los lineamientos de este "plan", Oiga creyó conveniente colocar los puntos tratados tal como fueron entregados a Paco Igartua por el pajarillo verde. Este documento estaba mecanografiado en cuatro cuadernillos que, con sus propias omisiones, faltas ortográficas, errores de contenido, de sintaxis o de dicción, fue transcrito íntegramente en el trabajo periodístico que, por su extensión, ocupó buena parte de dos ediciones de la revista. 
Por otro lado, respecto al titular a grandes caracteres de la portada de aquella Oiga del 12 de julio de 1993, que decía: "Historia de una traición", con el que la revista de Paco Igartua iniciaba la presentación de este documento, ello se debe al hecho de que Fujimori, durante su campaña electoral para postular a las elecciones de 1990, había prometido con bombos y platillos un gobierno diferente bajo el lema "honradez, tecnología y trabajo" que, finalmente, resultó ser un engaño. También había ofrecido que no habría un "shock" económico brutal -que había sido anunciado por su rival, Mario Vargas Llosa, lo que a la postre le quitó votos al escritor - , sino que habría ajustes graduales, a la medida de la realidad nacional, para acabar con la inflación de 700\% que había dejado en "herencia" el nefasto primer gobierno del líder aprista Alan García. Sin embargo, todos recuerdan aquella noche del 8 de agosto de 1990, tras el mensaje a la nación del entonces ministro de Economía, Juan Carlos Hurtado Miller hoy prófugo de la justicia por sus actos de corrupción-, donde anunciaba a un sorprendido país la aplicación de un draconiano "paquetazo económico" que dejó literalmente desamparada a la población, sin ningún plan de contingencia social previo por parte del gobierno fujimorista. Además, Fujimori había prometido "un millón de empleos"... pero terminó instaurando un régimen económico neoliberal que, a la larga, dejó en la calle a millones de trabajadores; igualmente, había ofrecido presentar un plan de gobierno coherente -cosa que sí hicieron sus ocasionales contendores -, que tampoco cumplió, hasta que apareció el famoso "Plan Verde", tema principal de este trabajo. Finalmente, ya en el poder, sin consultarle a nadie, quebró el orden constitucional con el autogolpe del 5 de abril de 1992 y cerró el Congreso y, para agravar la cosa, con la complicidad de malos elementos encumbrados en las Fuerzas Armadas y Policiales, se marcó el inicio de una serie de acciones militares de exterminio contra la población civil y una campaña de desinformación orquestada para que el ciudadano de a pie no se entere de que ya se estaba gestando secretamente el "plan" que aquí les mostramos. 


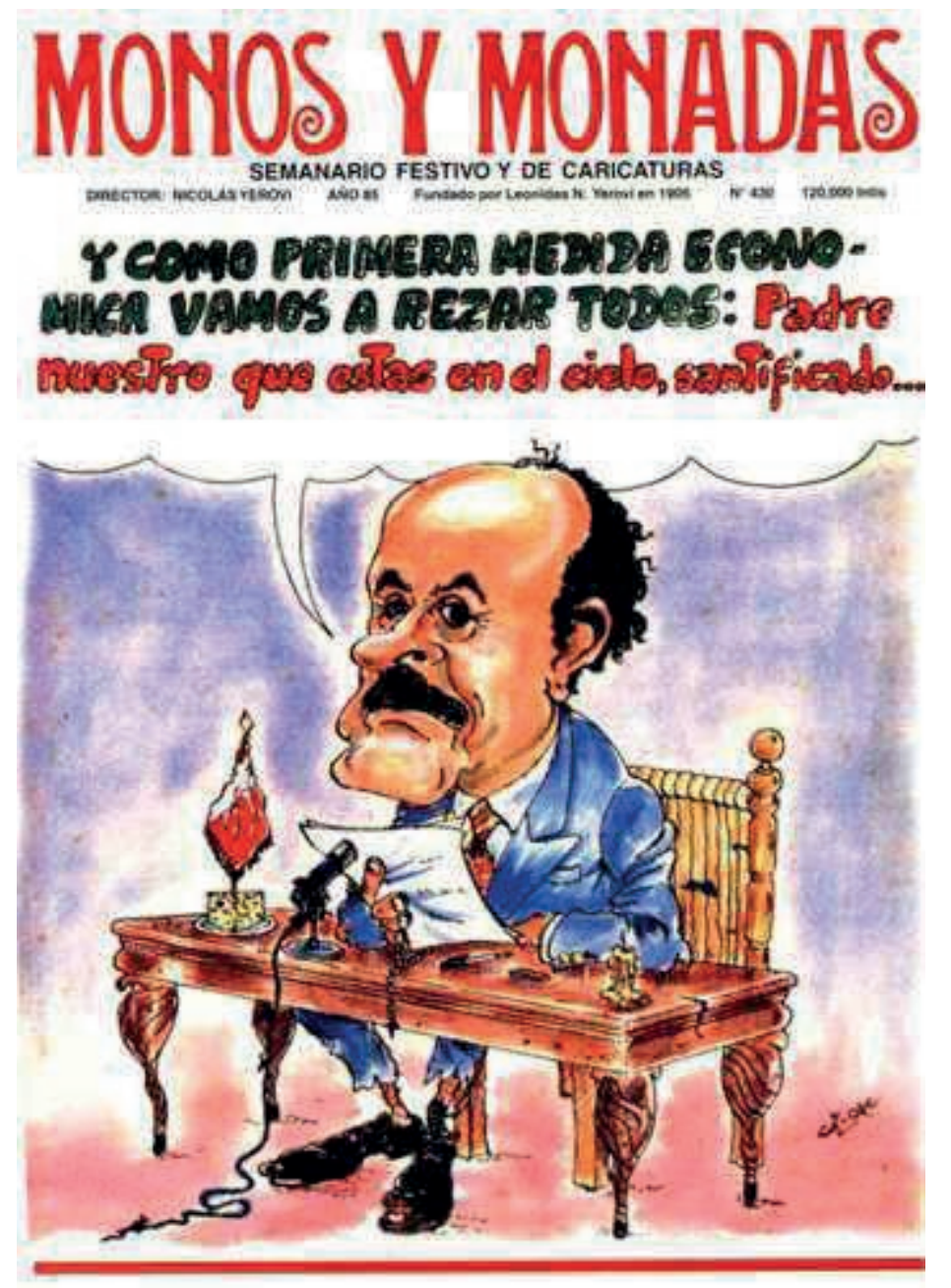

Figura 9. Haciendo cada vez más una involuntaria demostración de poderes adivinatorios, en la mañana del 8 /08/90 MONOS y MONADAS publicó esta carátula donde aprecia el entonces ministro de economía, vestido desastrosamente para conmover al país, rezando en público. Horas después. Hurtado Miller se dirigiría a la nación anunciando el tantas veces negado FUJISHOCK . Los bien pensados creyeron que por vergüenza, ya que se había asumido la Presidencia de la República esgrimiendo la frase "No Shock" seria el mismo chino quien daría el mensaje disculpándose acaso por esta su primera mentira de las muchas que se dieron en su gobierno. Ahora sabemos que lo que le sobro fue cobardia a falta de vergüenza. Y el ministro que dio la cara para anunciar el Shock económico terminó 
precisamente como lo había predicho esta humilde publicación: invocando un "que Dios nos ayude!!" (sic).

Ilustración del genial dibujante Javier Prado en la edición de "Monos y Monadas" del 8 de agosto de 1990, reproducida y comentada por Carlos Pérez "Sol Rac", en el blog dedicado a esta recordada revista cómico-política.

Luego, en el clímax de la guerra sucia emprendida por el gobierno fujimorista, un comando armado del Ejército Peruano, denominado "Grupo Colina", perpetró la matanza de civiles inocentes en el viejo suburbio limeño de Barrios Altos y el asesinato de nueve alumnos y un profesor de la Universidad Tomás y Valle, en la Cantuta, distrito de Chosica, cerca de Lima; finalmente, la denuncia por parte de la revista Oiga de la existencia "secreta" de este "plan" fue el corolario y la demostración de lo que no era un simple rumor. Por tal motivo, que no extrañe al lector la portada de aquella Oiga que nos ocupa, la del 12 de julio de 1993, donde, además de lo citado, decía en grandes caracteres lo siguiente: "28 de julio 90: Se inició plan militar de 20 años". Una semana después, el 19 de julio del mismo año, se publicarían las conclusiones de este siniestro informe, titulado: "Los 'Anexos' del golpe de Fujimori", el mismo que no dejó de causar más de un resquemor entre los personajes involucrados por este increíble testimonio periodístico (Nota 10) que, a resumidas cuentas, denunciaba lo que se temía: la peor dictadura de nuestra historia estaba en marcha, todo en medio del sopor de la sociedad civil, aturdida por los cantos de sirena del dictador. No cabía duda que el pueblo peruano había sido vilmente engañado por un mandatario corrupto y sin escrúpulos, que encabezaba un régimen totalitario e inhumano con la complicidad de ruines personajes, avalado por una prensa servil que no supo mantener su altura a toda costa.

Para evitar cualquier confusión o enredo respecto a la lectura del texto de este "plan", conviene aclarar que los renglones o párrafos que van con caracteres en cursiva, sin 
comillas, es texto original de Oiga, por lo general comentarios o apreciaciones de la redacción de la revista, para guiar a los lectores en la comprensión de lo que está leyendo, o de terceros autores, como iremos viendo. Por su parte, los renglones o párrafos que van en cursiva y entre comillas ("'"), es texto original del documento denominado "Plan Verde". Por otro lado, con el objeto de diferenciar el texto nuestro del de la redacción de Oiga y el del documento que presentamos, hemos creído conveniente que estos dos últimos vayan en cursiva, para facilitar su lectura.

Lo que sigue, entonces, es la primera parte de este informe, que comienza con el título y una "Introducción" que, como puede verse, va con una presentación y luego, más abajo, es comentado por la redacción de Oiga.

\subsubsection{El Plan Verde}

\subsubsection{1. "Introducción"}

"El presente Plan de Gobierno ha sido preparado por el equipo de trabajo dentro de una perspectiva de Estado Mayor, en el marco de un proyecto nacional necesario para llevar al país al siglo XXI con opción de alcanzar un nivel de país desarrollado.

En su elaboración ha sido lamentable constatar el alto grado de desarticulación en el que se encuentra el país, a raíz de la experiencia aprosubversiva (sic. N. de VA). (Nota 11)

Ha resultado penoso reconocer y aceptar la gravedad de los males que nos aquejan, hubiéramos querido arribar a conclusiones diferentes sobre las soluciones a los problemas estratégicos del Estado, sin embargo, la evidencia es de tal magnitud que hace imposible soslayar la realidad. 
El esfuerzo realizado ha estado ajeno a "ideologismos", hemos mantenido un espíritu pragmático al abordar los distintos temas tratados teniendo siempre presente solo los intereses de la patria.

El equipo de trabajo cumple con el misionamiento ordenado por el comando y agradece la confianza y asume la responsabilidad entregada."

"Viva el Perú"

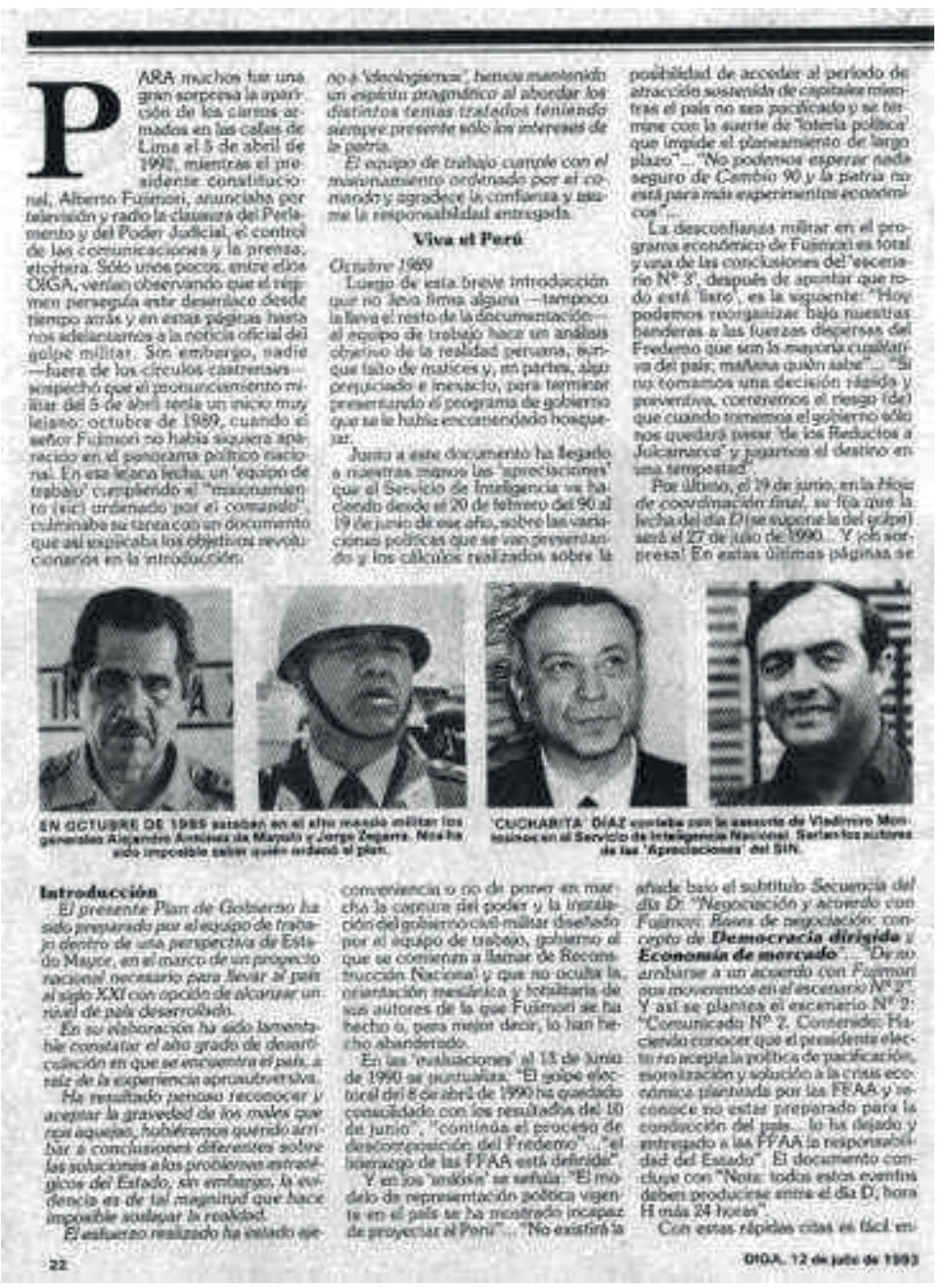


Figura 10. Facsímil de la página 22, primera del contexto Historia de una traición. Revista Oiga, 12 de julio de 1993.

Reproducción de stucchi.tripod.org

(Nota de Redacción: Suponemos que aquí termina la introducción, con este exclamativo pero lacónico "Viva el Perú", pero a continuación aparece una fecha, en cursiva y entre comillas (así como estaba escrito en el original de este documento), suponemos que podría tratarse de la fecha en que se terminó la redacción de este "plan" y, luego, como indicamos, Oiga comenta el texto, insertando afirmaciones del documento, es decir, del "plan", con su respectivo entrecomillado.)

\section{"Octubre 1989"}

Luego de esta breve introducción que no lleva firma alguna -tampoco la lleva el resto de la documentación - el equipo de trabajo hace un análisis objetivo de la realidad peruana, aunque falto de matices y, en partes, algo prejuiciado e inexacto, para terminar presentando el programa de gobierno que se le había encomendado bosquejar.

Junto ha este documento ha llegado a nuestras manos las "apreciaciones" que el Servicio de Inteligencia va haciendo desde el 20 de febrero del 90 al 19 de junio de ese año, sobre las variaciones políticas que se van presentando y los cálculos realizados sobre la conveniencia o no de poner en marcha la captura del poder y la instalación del gobierno civil-militar diseñado por el equipo de trabajo, gobierno al que se comienza a llamar de Reconstrucción Nacional y que no oculta la orientación mesiánica y totalitaria de sus autores de la que Fujimori se ha hecho o, para mejor decir, lo han hecho abanderado. 
En las "evaluaciones" al 13 de junio de 1990 se puntualiza: "El golpe electoral del 8 de abril de1990 ha quedado consolidado con los resultados del 10 de junio", "continua el proceso de descomposición del Fredemo" ... (Nota 12) "el liderazgo de las FFAA está definido".

Y en los "análisis" se señala: "El modelo de representación política vigente en el país se ha mostrado incapaz de proyectar al Perú"... "No existirá la posibilidad de acceder al periodo de atracción sostenida de capitales mientras el país no sea pacificado y se termine con la suerte de 'lotería política' que impide el planeamiento de largo plazo"... "No podemos esperar nada seguro de Cambio 90 y la patria no esta para mas experimentos económicos"...

La desconfianza militar en el programa económico de Fujimori es total y una de las conclusiones del "escenario $\mathrm{N}^{\circ}$ 3", después de apuntar que todo está "listo", es la siguiente: "Hoy podemos reorganizar bajo nuestras banderas a las fuerzas dispersas del Fredemo que son la mayoría cualitativa del país, mañana quien sabe"... "Si no tomamos una decisión rápida y preventiva, correremos el riesgo (de) que cuando tomemos el gobierno solo nos quedara pasar 'de los Reductos a Julcamarca' y jugarnos el destino en una tempestad".

Por último, el 19 de junio, en la Hoja de coordinación final, se fija que la fecha del día D (se supone la del golpe) será el 27 de julio de1990... Y oh! sorpresa! En estas ultimas paginas se añade bajo el subtitulo Secuencia del día D: "Negociación y acuerdo con Fujimori. Bases de negociación: concepto de Democracia dirigida y Economía de mercado"... "De no arribarse a un acuerdo con Fujimori nos moveremos en el escenario $\mathrm{N}^{\circ}$ 2". Y así se plantea el escenario $\mathrm{N}^{\circ}$ 2: "Comunicado $\mathrm{N}^{\circ}$ 2, Contenido: Haciendo conocer que el presidente electo no acepta la política de pacificación, 
moralización y solución a la crisis económica planteada por las FFAA y reconoce no estar preparado para la conducción del país... lo ha dejado y entregado a las FFAA la responsabilidad del Estado". El documento concluye con "Nota: todos estos eventos deben producirse entre el día D, hora H mas 24 horas".

Con estas rápidas citas es fácil entender como fue evolucionando el pronunciamiento militar hacia Fujimori y explica por qué éste dejó en la estacada, pronto y sin explicación alguna, a sus asesores económicos y se pasó instantáneamente a la "Economía de mercado". También aclara como pudo ser posible que Fujimori eliminara, sin correr ningún contratiempo, a los altos mandos de las FFAA el mismo día que asumió la presidencia, después de jurar, "ante Dios y estos Santos Evangelios", cumplir y hacer respetar la Constitución que acababa de comprometerse con el Ejército a violar y destruir.

El golpe del 5 de abril de 1992 no fue, pues, una decisión desesperada de un presidente que se sentía impotente para gobernar, porque el Parlamento obstaculizaba sus planes y el Poder Judicial no le permitía moralizar. Los pretextos esgrimidos por Fujimori ese día eran falsos. Nunca antes un Parlamento había otorgado con mas amplitud y facilidades poderes extraordinarios al ejecutivo, sobre todo en el terreno de la lucha antisubversiva, y hasta ahora Fujimori no ha detenido, no ha puesto entre rejas a un solo corrupto, ni a un solo narcotraficante, prueba de que el afán moralizador no fue ni es real. Ese día -5 de abril de 1992- se ejecuté el mismo plan de captura del poder diseñado por los militares en octubre de 1989: neutralización de AG y AM (Alan García y Agustín Mantilla), toma del Congreso, control de la prensa, etc. Los objetivos de entonces son los que ahora se están cumpliendo: Democracia dirigida, o sea autocracia, para que sea posible -según los golpistas - la economía de mercado al estilo de Chile. Como siempre, falta de imaginación y proclividad al calco y al calco más cercano a la vista, sin perspectiva y 
sin análisis de la diversidad de realidades. En todo el 'estudio' no hay dos líneas dedicadas a 'apreciar' el ejemplo colombiano, más exitoso que el chileno en el terreno económico y sin quebrantamientos del orden democrático. Sí se dedican muchos párrafos a Taiwán y a los otros tigres asiáticos. Ejemplos todos de países con gobiernos autocráticos y, quien sabe, muy ajenos a la realidad peruana.

(Nota de Redacción: Lo que sigue es una reseña de Oiga sobre la situación política que rodeó al gesto del personaje que hizo llegar el contenido del "Plan Verde" al despacho de Paco Igartua para su publicación en la revista a manera de denuncia contra la intentona totalitaria de Fujimori. Se menciona aquí a diversos actores de la escena política peruana, como es el caso de Alan García, a quien se sataniza sin dar otra explicación que una referencia a hechos conocidos de forma muy tergiversada, y comenta también los motivos, el cómo y el porqué fue redactado este informe, mencionando de pasada a sus posibles autores, un "equipo de trabajo" que, al parecer, utilizó las instalaciones del CAEM para preparar el documento, y también va el primer bosquejo de los objetivos de este "plan", una 'Misión' y la misión es: "Evaluar los escenarios nacionales próximo-futuros para escoger el mas adecuado y derrocar al gobierno civil, disolver los poderes Ejecutivo y Legislativo para que la Fuerza Armada institucionalmente asuma la conducción del Estado, con el fin de revertir la actual situación político-social-económica, cuyo deterioro amenaza destruir el sistema y las instituciones tutelares de la República" (sic) , es decir...) (Nota 13) 


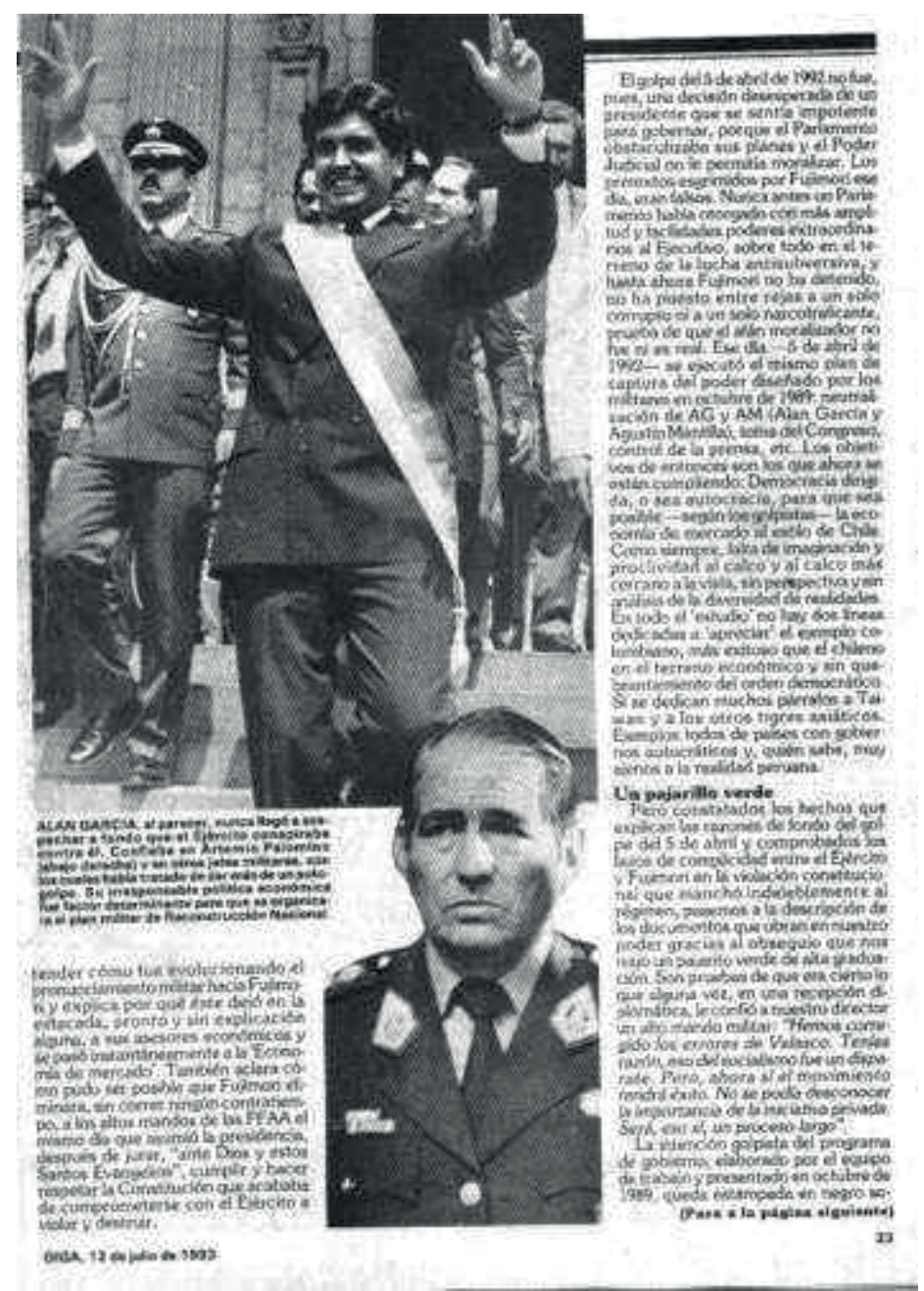

Figura 11. Facsímil de la página 23, segunda del contexto Historia de una traición. Revista Oiga, 12 de julio de 1993.

Reproducción de stucchi.tripod.org

\subsubsection{Un pajarillo verde}

Pero constatados los hechos que explican las razones de fondo del golpe del 5 de abril y comprobados los lazos de complicidad entre el Ejército y Fujimori en la violación constitucional que manchó indeleblemente al régimen, pasemos a la descripción de los documentos que obran en nuestro poder gracias al obsequio que nos trajo un pajarito verde de alta graduación. Son pruebas de que era cierto lo que 
alguna vez, en una recepción diplomática, le confió a nuestro director un alto mando militar: "Hemos corregido los errores de Velasco. Tenías razón, eso del socialismo fue un disparate. Pero, ahora sí el movimiento tendrá éxito. No se podía desconocer la importancia de la iniciativa privada. Será, eso sí, un proceso largo".

La intención golpista del programa de gobierno, elaborado por el equipo de trabajo y presentado en octubre de 1989, queda estampada en negro sobre blanco en el cuadernillo que va elaborando el Servicio de Inteligencia Nacional a partir del 20 de febrero de 1990. El punto primero en el índice de 'apreciación de inteligencia' lleva el título de 'Misión' y la misión es: "Evaluar los escenarios nacionales próximo-futuros para escoger el más adecuado y derrocar al gobierno civil, disolver los poderes Ejecutivo y Legislativo para que la Fuerza Armada institucionalmente asuma la conducción del Estado, con el fin de revertir la actual situación político-socialeconómica, cuyo deterioro amenaza destruir el sistema y las instituciones tutelares de la República".

En esa época gobernaba Alan García y el Servicio de Inteligencia estaba bajo las órdenes del general Edwin (Cucharita) Díaz, quien tenía de asesor al doctor Vladimiro Montesinos, capitán retirado del Ejercito. Este asesoramiento no era muy visible, pero sí decisivo.

Alan García, el desastroso presidente que las mayorías nacionales eligieron, ilusionadas por su juventud y empuje -a la corta el empuje solo fue verbal - , dormía tranquilo en Palacio, confiado en 'Cucharita' Díaz y en el comandante general del Ejercito, su amigo Artemio Palomino. Al parecer García nunca sospecho de su jefe de Inteligencia y, tampoco, ni se entero quien era el consejero del SIN. Tampoco advirtió que el jefe del Estado Mayor, general Alejandro Antúnez de Mayolo, y el general 
Jorge Zegarra -comandante general de 1990 - tenían posición muy diferente a la de Artemio Palomino y a la corte militar de Alan García.

(Nota de Redacción: Un rápido y sesgado esbozo de la realidad histórica peruana es utilizado para justificar el diseño de un "plan de gobierno", redactado con muy poco criterio por el "equipo de trabajo" al que se encomendó la tarea de estudiar y preparar lo que el lector está viendo. Este apartado es tal vez el más siniestro de este documento, pues aquí se menciona, por primera vez, el término "excedentes poblacionales" y plantea los "métodos" a ser aplicados para su "ejecución" o "exterminio". No contenta con transcribir el contenido de este texto, la revista Oiga analiza punto por punto lo que sigue a continuación.)

\subsubsection{Plan de Gobierno}

Es en estas circunstancias que el 'Comando' -en los documentos no se revela nombres - ordena al equipo de trabajo la elaboración de un Plan de Gobierno, con su correspondiente análisis de la situación político-social-económica del país. Esto debió ocurrir antes de octubre del 89 -fecha de la entrega del trabajo - pues se trata de un estudio muy detallado de la realidad peruana y sus proyecciones.

El Gobierno de Reconstrucción Nacional diseñado por el Ejército en 1989, ya organizaba un 'Sistema Nacional de Control, Seguridad y Propaganda', que "sí, definitivamente, equivale a una Gestapo", según consta en uno de los anexos de los Documentos que nos dio un pajarito verde. (Texto Redacción de Oiga)

Comienza el trabajo con un apurado y superficial recuento de la "evolución y características del Estado en su etapa republicana", en el que destacan algunas clamorosas inexactitudes, como afirmar que el inicio de la Seguridad Social fue en 1950. Ignora el 'equipo de trabajo' que ese inicio y el Hospital Obrero fue obra de un 
militar, el mariscal Benavides, concretada en la década de los treinta. También con gran simplicidad, se afirma que "el Perú perdió, en los años sesenta, su mejor oportunidad de integrarse a la dinámica económica mundial", por culpa de la Cepal (Comisión Económica para América Latina y el Caribe. N. de VA) y de su aliento a la sustitución de importaciones. Ignora el equipo que fue justamente la sustitución de importaciones la primera herramienta para el despegue económico de la mayoría de los tigres asiáticos. La diferencia entre esos países y América Latina estuvo en que Asia usó la sustitución para acumular capitales y lanzarse a la conquista de los mercados del exterior, mientras que en nuestra región sólo sirvió para que una minoría viviera espléndidamente y abriera cuentas bancarias en el exterior.

Al llegar a la etapa de la 'revolución' militar del 68, el análisis se torna más agudo y concluye en que los grandes males por corregir --hipertrofia del Estado empresario, masificación de la enseñanza, aliento a la explosión demográfica, desarrollo burocrático, endeudamiento exterior, excesivos gastos militares - se gestaron y consolidaron en los años sesenta. También apunta que la incipiente acumulación de capitales que, mal que bien, se había iniciado en esos años, quedo bruscamente congelada con el gobierno militar.

Todos esos males no fueron afrontados en el gobierno civil del 80 al 85 . Al contrario, "incorporo 150000 empleados a la planilla fiscal...", "estructura burocrática que constituye una traba cada vez mas grande e incoherente al desarrollo de las fuerzas productivas, constituyendo un obstáculo al desarrollo nacional".

La administración aprista es calificada de "el colapso final de la estructura del Estado", para luego enumerar todos los desastres debidos al Apra, entre ellos la incorporación de 300 mil nuevos empleados a la burocracia estatal, emisión monetaria fiscal e hiperinflación, incremento de la fuga de capitales, recesión... 
La tendencia a la economía liberal de mercado asumida por las FFAA se pone en evidencia en las consideraciones que se hacen sobre la 'mentalidad eficiente', que se debe guiar por "el prerrequisito fundamental de la actividad empresarial, que es: el beneficio o la perdida que la empresa reporte estimula o castiga directamente a los interesados o gestores". Todo esto en contraposición al Estado-empresario que "altera el principio de costo-beneficio, distorsiona la mentalidad de los recursos empleados al ser estos mal utilizados y anula su competitividad, desanima a los agentes productivos que saben conscientemente o intuyen que sobre ellos va a apoyarse esta carga injusta y desproporcionada".

A la lucha contra la inflación, que es tratada en este capítulo, se une la guerra al terrorismo. "Guerra que debería obligar al Estado a un planteamiento de prioridades militares, modificando la doctrina de defensa y modificando las hipótesis de guerra existentes con anterioridad al fenómeno terrorista".

Poco a poco el lector irá observando que los novedosos planteamientos que va exponiendo hoy el señor Fujimori se parecen muchísimo a las ideas plasmadas en este plan de gobierno diseñado por los militares en 1989. En los 'objetivos nacionales de largo plazo', por ejemplo, se admite que es necesario aceptar que el concepto territorial en la delimitación de los intereses de la soberanía de los estados ha sido desbordada y que estos intereses se refieren a la mayor o menor presencia relativa en los distintos mercados mundiales", "Por lo tanto el poder nacional es asimétrico con el stock bélico y es simétrico con la capacidad de dichos estados en organizar moderna y eficientemente sus unidades productivas orientadas hacia el comercio exterior".

De todo esto se deduce que es tarea central atraer capitales de inversión, para lograr incrementar el poder nacional, "orientado hacia una estrategia de proyección en el 
siglo XXI, planteando los problemas estratégicos del Estado y sus drásticas soluciones".

Como se aprecia, el lenguaje, por lo general, es sosegado, propio de tecnócratas universitarios, pero de vez en cuando suenan o resuenan tacones castrenses. Como en el capítulo que sigue, dedicado a "los problemas estratégicos en la consecución de los objetivos a largo plazo".

Los problemas de corto plazo -según el documento militar que tenemos a la vistason la desarticulación económica, la excesiva y distorsionante intervención del Estado en la vida económica y social del país y el auge de la subversión. Esto es lo urgente. Pero lo importante "reside en que las tendencias demográficas han alcanzado proporciones de epidemia... De nada servirá derrotar a la subversión si seguimos incrementando en 500 mil personas anuales la demanda de alimentos, educación, servicios, vivienda, agua, energía".

"Hay clamorosas inexactitudes como desconocer que un militar, el Mariscal Benavides, fue el iniciador del Seguro Social y constructor del Hospital Obrero". (Texto Redacción de Oiga)

Y se añade lo que sigue: "Ha quedado demostrado la necesidad de frenar lo más pronto posible el crecimiento demográfico y urge, adicionalmente, un tratamiento para los excedentes existentes: utilización generalizada de esterilización en los grupos culturalmente atrasados y económicamente pauperizados. Sin estas cargas innecesarias, se facilitaría el acceso de grupos familiares débiles a ciertos niveles de bienestar". "Los métodos compulsivos deben tener sólo carácter experimental, pero deben ser norma en todos los centros de salud la ligadura de trompas". 
Más aún: "Hay que discriminar el excedente poblacional y los sectores nocivos de la población. Consideramos a los subversivos y a sus familiares directos, a los agitadores profesionales, a los elementos delincuenciales y a los traficantes de pasta básica de cocaína como excedente poblacional nocivo"

Naturalmente que se trata de un documento-propuesta, hecho por el equipo de trabajo, que debe haber sido revisado por el Comando, ya que a continuación propone algo espeluznante: "Para estos sectores, dado su carácter de incorregibles y la carencia de recursos... solo queda su exterminio total".

(Nota de Redacción: A propósito de los términos excedente poblacional nocivo y exterminio respecto a las mujeres andinas, y coincidiendo con las apreciaciones vertidas sobre estos espeluznantes puntos por la revista Oiga, el investigador peruano Gonzalo E. Gianella, en su trabajo: ¿Por qué tendría que haber sucedido de este modo?: Notas sobre esterilizaciones y genocidio en el Perú?, no puede dejar de comentar los siniestros designios del "Plan Verde", cuando añade: No es materia de este artículo determinar el grado de influencia que el Plan Verde tuvo en el desarrollo de las políticas de estado durante el gobierno de Fujimori. Si bien el fujimorismo utilizó métodos muy similares a los detallados en el Plan Verde (PV), sería apresurado tomarlo como la única guía de acción del régimen fuji-montesinista. Hecha esa salvedad, la historia del PV posee una serie de elementos que merecen análisis. Lo primero es que, de acuerdo a diversas versiones periodísticas, el PV habría sido escrito por elementos allegados o miembros del aparato de inteligencia de las fuerzas armadas del Perú. Segundo, este documento fue elaborado a finales del gobierno de Alan García e incluye anexos añadidos luego de la elección de Fujimori en 1990. Tercero, mediante la Revista Oiga, el PV vio luz pública en julio de 1993. Así, para fines de 1993, en un país completando casi dos años de gobierno cívico militar, era de dominio público la existencia de un documento escrito por 
peruanos, aparentemente allegados a las fuerzas armadas, que mencionaba específicamente el uso de esterilizaciones forzadas como parte de una política de estado.)

Nota de Redacción: Luego, Oiga sigue escribiendo...

Posteriormente se ocupa el equipo de trabajo de la 'hoja de coca', como "principal recurso estratégico del país".

Aquí se plantea el problema de la coca como el más importante recurso para las negociaciones con Estados Unidos y se trazan lineamientos generales de una política cocalera que más tarde enfrentará, ya en el gobierno de Fujimori, y Vladimiro Montesinos con Hernando de Soto, con el previsible apartamiento de este ultimo. (Sobre este tema hay un anexo II que no ha llegado a nuestras manos).

Dentro del desorden y la insistencia en algunos temas que tipifican este documento se trata enseguida de la "necesidad de la reestructuración del Estado... y de que la reducción del aparato burocrático sea el máximo posible, lo mismo que la transferencia de las empresas públicas al sector privado nacional o vía conversión de deuda". Se exige a la vez que todo esto se haga "con racionalización eficaz y rápida de los recursos humanos, para garantizar el funcionamiento efectivo de los servicios y la infraestructura del pais en los esfuerzos de la guerra con los grupos subversivos".

También hay cabida para desarrollar con amplitud la conveniencia de integrarnos con el Brasil -tesis a la que antes se oponía la Fuerza Armada peruana-, con miras a la "proyección conjunta a la Cuenca del Pacifico en el siglo XXI". El tema es tratado 
con gran sensibilidad geopolítica y "ecopolítica" (¿Habrá querido decir: economía política? N. de VA).

Y, dentro de esta política de acrecentar el poder nacional, sigue un tratamiento minucioso de la necesidad de "atraer capitales de riesgo"... Continúa con el problema de la educación. La conclusión es que el actual servicio educacional "es una farsa" y es "gratis a la peruana", o sea gratis para el que lo consume y caro para la ciudadanía. La solución es que "que el Estado debe retirarse lo más pronto posible de la enseñanza media y reordenar su presencia en la educación superior".

Bastan los párrafos que siguen para ilustrarnos sobre la orientación 'pragmática' esto también es una ideología - de la política educativa trazada en el documento del equipo de trabajo. Como se ve, no difiere en nada con las ideas que va 'descubriendo' Fujimori:

"Dado que la calidad de la formación de la enseñanza media es sumamente baja, el Estado debe prestar atención preferente solo a aquellos recursos humanos que muestren alto nivel de preparación. El ingreso a primer y tercer año de media deben ser filtros poderosos, los que no superen estos filtros o resulten desaprobados, deberán tratar de completar su educación en el ámbito privado. Lo contrario sería malgastar los escasos recursos en quienes no tienen aptitudes".

"El ingreso de niños a la educación primaria a cargo del Estado deberá estar acondicionado a la adopción, por parte de los padres, de la política poblacional que el Estado elija".

Luego el documento se ocupa de cada uno de los sectores del aparato estatal, en lo que viene a ser su puntual programa de gobierno. En el cuadernillo que obra en nuestro poder, al capítulo que, suponemos, debe titularse Economía, le faltan dos 
hojas, pero en la última página -que sí está en nuestras manos - se hallan los objetivos de largo y corto plazos y el comentario final. Son suficientes para descubrir la línea a seguir: lograr una economía estable con un crecimiento sostenido y balanceado a nivel regional, en concordancia con los objetivos nacionales a largo plazo; pero antes "hay que acabar con la hiperinflación y dar señales concretas al sector privado, respecto al papel protagónico que se le va a dar en el proceso de desarrollo nacional". El 'comentario final' insiste en lo mismo: "Acabar con la hiperinflación rápidamente seria el éxito político de corto plazo mas importante...".

El resto, política exterior y aranceles, es liberalismo puro: apertura de mercados, baja de aranceles, 'reinserción', FMI, Banco Mundial, Club de Paris, etc., etc., etc.

Las políticas propuestas para cada sector -Pesquería, Minería, Educación, etc. responden a los lineamientos generales reseñados en las páginas anteriores; salvo una que otra novedad, que no resultan de interés para el lector en general. Daremos cuenta de ellas al final de esta nota, que es de esperar resulte verdadera primicia para nuestro público y sean tomados como apuntes básicos para el rescate de una verdad histórica, hasta hoy escamoteada por los brillos y resplandores de la agitada actualidad que nos está tocando vivir.

(Nota de Redacción: Debido a la extensión original de lo que sigue a continuación, Oiga ha resumido para su mejor análisis y comprensión el contenido referente al Inquietante paso a paso del Servicio de Inteligencia Nacional, que detalla la 'misión' que ha de cumplir el SIN "Evaluar los escenarios para escoger el más adecuado y derrocar al gobierno civil y disolver el Parlamento..." No olvidemos que estamos hablando del momento en que fueron redactadas estas líneas, es decir, fines del año 1989, previo a las elecciones generales que, a la postre, fueron ganadas por Fujimori. 
Este, por cierto, cumplió a medias con esta 'misión' ... dar un "autogolpe" y disolver el Congreso un 5 de abril de 1992, con la anuencia de las Fuerzas Armadas...) Volver al principio del parágrafo Volver al principio del capítulo Volver al principio del artículo Volver al principio

\subsubsection{Inquietante paso a paso del SIN}

El documento más atractivo de los cuatro cuadernillos que han llegado a nuestras manos, es el titulado: "Apreciación de Inteligencia". "Los más urticantes son los anexos."

Es en realidad el seguimiento que el Servicio de Inteligencia Nacional va haciendo de los sucesos políticos, económicos y sociales que se van produciendo en ese lapso; y su evaluación, en relación con el documento anterior, y las recomendaciones estratégicas y tácticas que es necesario emplear para la consecución de los objetivos trazados en el programa de octubre del 89.

Ya hemos transcrito la 'misión' que debe cumplir el SIN: "Evaluar los escenarios para escoger el más adecuado y derrocar al gobierno civil y disolver el Parlamento..."

El escenario comienza con Alan García de presidente y una cúpula militar incapaz que le hace la corte. Se trata pues, de un golpe militar contra la situación aprosubversiva, tal como es calificada en los documentos.

Al leer las páginas se va viendo cómo va variando de tácticas la conspiración, aunque la estrategia no cambia ni cambian sus objetivos. Lo más sorprendente es ver cómo logran descubrir, a último minuto, al cabecilla ideal para el golpe militar: un civil que ha sido elegido presidente. Es como si les hubiera caído del cielo la solución, aunque 
es de dudar que el cielo haya amparado tan grande y grave traición a la Constitución y a la democracia. Traición planeada y aceptada poco antes de presentarse Fujimori ante el Congreso para jurar en vano, conscientemente, y recibir del Congreso el cargo de Presidente Constitucional.

(Nota de Redacción: Los de abajo son párrafos resumidos y algunos completos del texto original del "plan" seleccionados por la redacción de la revista Oiga, que pretende analizar la situación previa a los comicios electorales de 1990. Sin más comentarios...)

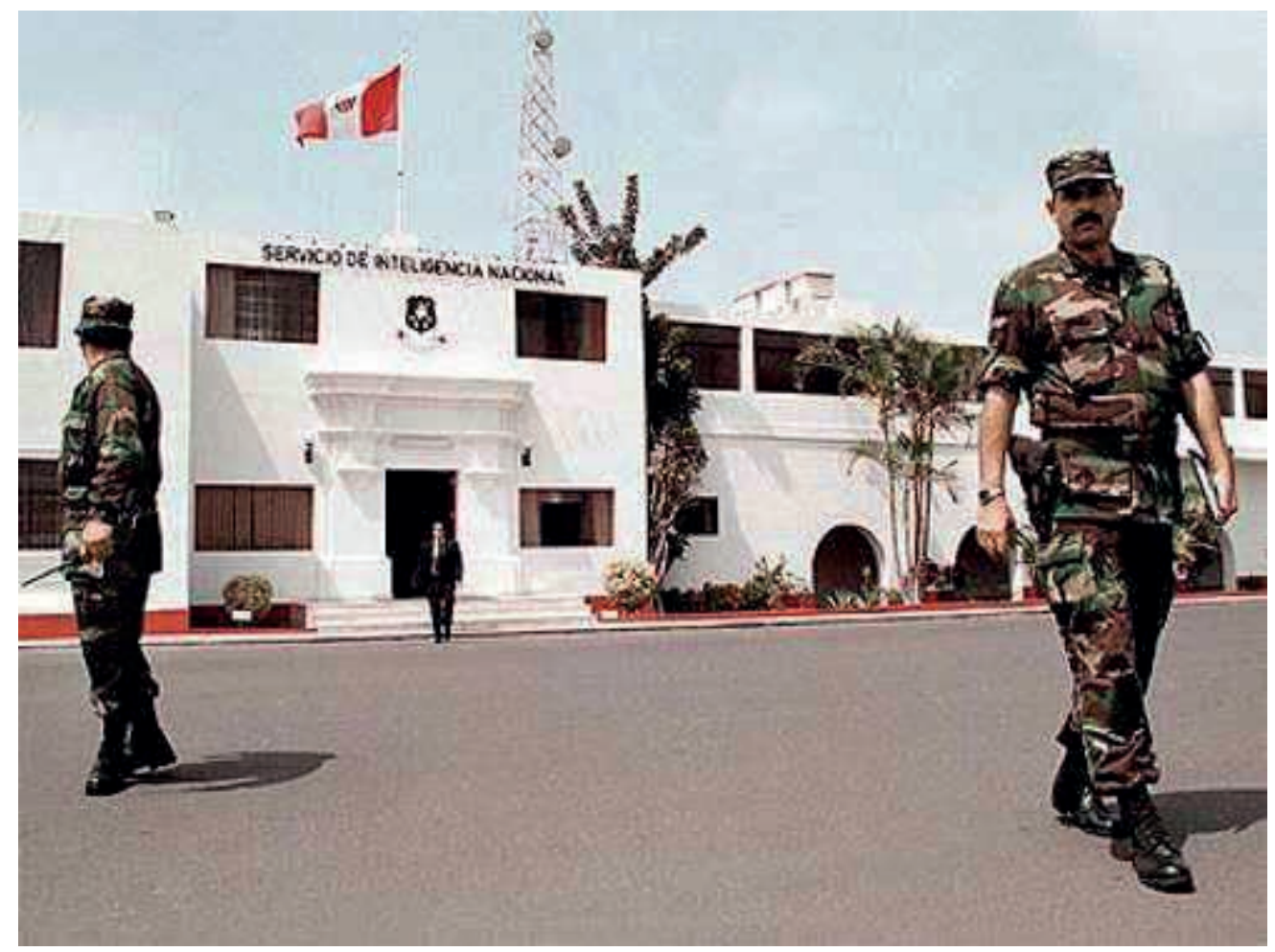

Figura 16b. SIN... comentarios. Tanto a lo largo del texto del "Plan Verde" como en las macabras acciones del Grupo Colina y en las compras de conciencias éticas y morales, en procura de la sumisión de voluntades y adhesiones políticas para la fracasada reelección del "japonés presidente", que sino de la "compra" de líneas editoriales de medios de comunicación para manipular a la prensa y a la opinión 
pública -coimas y sobornos dixit-, el protagonismo del otrora Servicio Nacional de Inteligencia y del "doc", Vladimiro Montesinos, marcaron una constante en esta historia de embarrados y cochinos. Aquí, en este edificio, se pudrió la dignidad nacional, además de que desde acá se hizo correr mucha sangre inocente.

Foto del reportaje "La libreta de Montesinos", publicada en la revista Caretas el $4 / 3 / 2004$

\subsubsection{Apreciación de Inteligencia}

La evaluación se inicia con un análisis de la 'situación general' al 20 de febrero de 1990:

a) "La descomposición social así como las tensiones políticas propias de la época subversiva-electoral que se vive, configuran un cuadro caracterizado por el caos, donde se advierte claramente la ausencia del sentido de autoridad y de determinación para modificar este curso" (Es resumen).

b) "El saldo que está dejando la actividad subversiva desde 1980, tanto en pérdidas humanas como materiales, ha rebasado las posibilidades reales y sicológicas del país". (Es resumen)

c) "Las posibilidades de que el gobierno en los próximos meses pueda manejar la situación económica en cierto equilibrio son limitadas y éstas tendrán como fundamento medidas cortoplacistas y electoreras que comprometerán tanto al proceso de transferencia como al primer año del próximo gobierno, independientemente de la orientación política y económica de la administración que asuma. Para que se tenga una idea de la gravedad de la crisis, debe citarse que las 
correcciones tendrán que ser de una magnitud mucho mayor al ajuste de setiembre de 1988".

d) "En síntesis, las previsiones sobre un proceso electoral, transferencia de gobierno, y los próximos meses de la nueva administración del país dentro de un marco ordenado, carecen de realismo y podrían conducir a la República al desencadenamiento de una convulsión social generalizada. En estas condiciones solo las fuerzas del orden en la conducción de la política del Estado pueden garantizar la unidad de la mayoría de la población y la iniciación de un proceso de construcción nacional, al margen del sistema democrático establecido en la Carta Magna."

A continuación de este análisis de la situación general al 20 de febrero de 1990, se estudian las 'características del área de operaciones'. Destacándose en este estudio la importancia que tiene en el sostén de la subversión, tanto de Sendero como la del MRTA, la 'izquierda legal'. "En la llamada izquierda legal existen sectores proclives a la lucha armada, que consideran que el objetivo prioritario de su programa no es combatir a las agrupaciones que practican el terror y el crimen..."

Reconoce en estas páginas el Servicio de Inteligencia, aunque no lo prevé abiertamente todavía, la importancia que tendrá, para desarticular la subversión y, sobre todo, para que pierda apoyo y abastecimiento de cuadros, la caída universal de las ideas marxistas, el gran aliento violentista en las universidades, educación y sindicatos, todas ellas canteras de Sendero y el MRTA.

(Nota de Redacción: Todo lo que sigue a continuación en cuanto a Caracteristicas del área de operaciones con sus diferentes "factores"(nos imaginamos que se trata del campo o campos de acción de este proyecto de gobierno nacional) es texto original 
del "plan"; la redacción de Oiga se ha limitado a transcribirlos tal como están, por lo que huelgan comentarios.)

\subsubsection{Características del área de operaciones}

1) Factores generales

a) Factores políticos

(1) El primer elemento que debe tenerse en cuenta visando el cumplimiento de la misión es la estructura política y paramilitar del partido gobernante.

(2) Un segundo escalón a considerar son los partidos políticos, aunque ahora integran el frente electoral Fredemo, tienen una posición decididamente en contra de la interrupción del sistema constitucional.

(3) "La izquierda legal, agrupada ahora en la Izquierda Unida e Izquierda Socialista. En este sector predomina la prédica, generalmente solo formal en defensa del sistema democrático, no porque se interesen realmente en preservarlo, sino como posición táctica y su preocupación porque las FFOO signifique una posición represiva contra ellos."

(4) El fracaso de los dos últimos regímenes democráticos habría producido en el grueso de la opinión pública, una actitud de rechazo hacia las agrupaciones partidarias tradicionales, incluyendo a los dirigentes de mayor figuración y trayectoria. Evidencia de esta apreciación son los resultados electoral municipal (sic. $\mathrm{N}$. de VA) en Lima, que permitió el acceso a la alcaldía de Ricardo Belmont Cassinelli. 
"En Brasil se encontraría apoyo por la línea liberal del movimiento, coincidente con la de Collor de Melo".

(Redacción de Oiga)

(Nota de Redacción: En el texto original de este "plan", en este acápite 1. Factores generales se ha introducido el punto a) Factores generales, pero se ha omitido el punto signado con la letra "b", por lo que se continúa con el punto "c")

c) Factores Sociales

(1) En la última década, el país a ingresado a una etapa crítica, que se vino incubando probablemente desde tiempo atrás, pero que en la actualidad se manifiesta, por un lado, a través de la actividad creciente de los grupos subversivos Sendero Luminoso y MRTA, cuyo accionar no es ya como el de las guerrillas de los años sesenta, una etapa episódica y focalizada que puede ser erradicada en pocas semanas mediante una operación militar contundente, como sucedió con el alzamiento del MIR en el año 1965. "La vigencia sostenida y creciente de estas agrupaciones terroristas, imbuidas de una predica política marxista es posible, en gran parte, por la situación convulsiva que vive la República, que les permite reclutar sin mayor dificultad, el sector social marginado y más duramente castigado por la crisis", que ingresa diariamente a las filas de la subversión, no porque adhiera voluntaria y conscientemente a las tesis complicadas del senderismo, sino porque la metodología violentista de los grupos subversivos ofrece a estos la oportunidad de descargar el resentimiento que han acumulado por sus frustraciones de orden económico y social. 
(2) Los grupos subversivos SL y MRTA son en realidad las expresiones más extremas del estado de convulsión por la que atraviesa la sociedad peruana. En la llamada "izquierda legal" existen sectores proclives a la lucha armada, que consideran que el objetivo prioritario de su programa no es combatir a las agrupaciones que practican el terror y el crimen como método cotidiano, sino a la denominada 'derecha', término en el que agrupan al gran empresariado y a los partidos que hoy integran el Fredemo.

En el personal subalterno de las Fuerzas Policiales, también está latente esta actitud violentista y agresiva que ha quedado demostrada fehacientemente en las paralizaciones policiales de los años 1983 - 1987 y más recientemente el 16 de octubre de 1989. Las manifestaciones de confrontación alcanzan a las denominadas 'organizaciones populares', como los clubes de madres, asociaciones vecinales y otras agrupaciones que habitan principalmente en los barrios marginales de la capital de la República. En el interior del país, los frentes de defensa departamentales han sido infiltrados por la subversión o simplemente han perdido su vigencia y representatividad.

(3) Esta nueva realidad, caracterizada por el crecimiento constante de la subversión, el agravamiento de las desigualdades sociales, la confrontación política y la agudización de las pugnas electorales con miras a los próximos comicios generales, "indica con toda nitidez, que una eventual intervención de la Fuerza Armada en la conducción política del país tendría no solo un costo social altísimo en relación con situaciones anteriores, sino que además, tendría que planificarse teniendo en cuenta el crecimiento significativo que se ha operado en la capacidad de respuesta de los sectores que se verían afectados por dicha intervención."

d) Factores militares 
(Nota de Redacción: En la versión original del informe contenido en el presente reportaje de Oiga se omite el acápite 1)

2) En el combate cotidiano contra la acción desestabilizadora de los grupos subversivos SL y MRTA, la Fuerza Armada ha visto mellada su imagen de eficiencia que siempre ha tenido frente a la ciudadanía, porque las limitaciones en el aspecto logístico la colocan en una situación de desventaja frente a un enemigo de efectivos reducido pero de gran movilidad, el cual además aprovecha hábilmente la venta que le da la indiferencia o la complicidad, en muchos casos, de importantes sectores de la población civil. La posición institucional de las FFOO está comprometida además por la acción sicológica de la subversión, en alianza táctica con grupos de la izquierda legal, algunos medios informativos importantes y organismos dedicados a la defensa de los derechos humanos, los cuales explotan el concepto de la denominada 'guerra sucia', contribuyendo así no solo al avance de la subversión sino también al cuestionamiento sistemático del modelo contrasubversivo. En este marco, los integrantes de las fuerzas regulares del Estado viven sometidos en forma permanente y a veces implacable a la acción fiscalizadora de los organismos como la Fiscalía de la Nacion y el Poder Judicial que justamente, por ser partes integrantes del Estado, debieran respaldar la acción de la fuerza que les garantiza su supervivencia."

(Nota de Redacción: En este acápite dedicado a Geopolítica, narcotráfico y aspectos sicológicos, la redacción de Oiga ha optado por seleccionar y transcribir las apreciaciones más significativas de este apartado, que analiza con profundidad los aspectos más delicados de la problemática nacional -como es el caso de nuestras relaciones con los países vecinos-, pero de forma tan desafortunada, tal vez demasiado apasionada como poco realista. Resulta paradójico constatar la reiterada aparición del SIN(Sistema de Inteligencia Nacional) en todos estos esquemas, como si 
en el Servicio de Inteligencia Nacional se hubiera diseñado todo el contenido del futuro tinglado político que se pretendía implantar en el Perú a la buena o a la mala...)

Volver al principio del parágrafo Volver al principio del capítulo Volver al principio del artículo Volver al principio

\subsubsection{Geopolítica, narcotráfico y aspectos sicológicos}

Termina este estudio de las 'características del área de operaciones' con un tema sumamente delicado, que solo resumiremos a continuación.

Afirma el SIN que "hay que asumir que los países fronterizos del Perú están evaluando en forma constante esta situación, que compromete de manera peligrosa al sistema de defensa nacional, no solo en lo que podría estar relacionado al equilibrio de los respectivos potenciales militares de la región, sino también respecto a la posición que nuestros vecinos asumirán en caso de que se instale un gobierno militar en el Perú".

Cree el SIN que en el Brasil se encontraría apoyo por la línea liberal que tendría el movimiento, coincidente con la de Collor (de Melo. N. de VA), que acaba de ganar las elecciones brasileñas. En Chile, "la victoria de la oposición establece un equilibrio delicado entre el gobierno saliente y el entrante"... Y así se van descartando reacciones contrarias, en Ecuador y Colombia, a un cambio traumático en el Perú. Sobre el grupo de los 8 dice que "la invasión de Panamá desinflo su capacidad de maniobra o articulación".

El documento pasa luego a tocar, muy brevemente, el "Problema del narcotráfico" insistiendo en que "las relaciones con USA girarán, no sobre las características 
democráticas o de DDHH, sino sobre la estrategia en este tema". Y recuerda que el plan político preparado en octubre de 1989 considera la coca como "el segundo problema estratégico del Estado, después de la política poblacional en la primera mitad del siglo XXI".

Después de criticar al Servicio de Inteligencia anterior y destacar la desmoralización y corrupción en la policía y en algunos sectores de las FFAA, pasa a los 'Aspectos sicológicos'.

(Nota de Redacción: Como ya se habrá dado cuenta el lector, la redacción de Oiga analiza a continuación el contenido de los Aspectos sicológicos, donde los redactores del "plan" hablan del accionar y el comportamiento de los grupos de izquierda de la sociedad peruana, en especial de la subversión, emitiendo luego unas "sugerencias" acerca de cómo se podría "manejar" o "manipular" la respuesta social y política de la población. Por otro lado, se denotan aquí apreciaciones muy generalizadas en las que grupos humanos, muchos de ellos de izquierda o de centro-izquierda, y no pocos de otras tendencias políticas, pero de ninguna manera vinculados con el terrorismo, así como las organizaciones de derechos humanos, la llamada "Iglesia Progresista" (sic), los comités vecinales o las asociaciones de comedores populares, que nada tenían que ver con la violencia interna o con la subversión, son puestos en el mismo saco que los grupos terroristas, como Sendero Luminoso y el MRTA -el tristemente célebre Movimiento Revolucionario Túpac Amaru -, descritos en estas líneas.) Como notará el lector, en este acápite se ha omitido el punto \# 1 para continuar con el siguiente, \# 2, que trata sobre Aspectos sicológicos.

2) Aspectos sicológicos

a) Impregnación ideológica y propaganda 
Los grupos de izquierda leninista, como parte de su accionar subversivo ha realizado un sistemático trabajo de orden sicológico para conseguir el desprestigio de las instituciones y valores nacionales, particularmente los referidos al ordenamiento democrático y a la doctrina y previsiones de la seguridad nacional.

Se ha desarrollado, igualmente, un trabajo prioritario de infiltración e impregnación ideológica en los sectores vinculados a la educación y a la comunicación social para ejercer una influencia dominante sobre los medios transmisores de la cultura y la formación de la opinión pública nacional.

Al respecto, estas agrupaciones han logrado:

- El control mayoritario de los tres estamentos de la Universidad Peruana.

- Una influencia dominante sobre el magisterio nacional, la que se mantiene a través del Sutep (Sindicado Unido de Trabajadores de la Educación Pública. Nota de VA).

- El control hegemónico de las organizaciones de estudiantes secundarios, a los que se busca convertir en mecanismos de presión política con una dimensión nacional.

- Una presencia significativa, por la vía específica de la infiltración, en los cuadros directivos y técnico profesionales del sector educacional, particularmente a nivel de los núcleos educativos y de las aéreas de investigación, capacitación y diseño curricular.

- Una influencia sustantiva en los sectores intelectuales y culturales del país; así como en las organizaciones de periodistas y de los trabajadores gráficos.

A nivel de la población, la impregnación ideológica viene tratando de conseguir a partir de la 'politización' masiva de los sectores populares; la generación de un 
movimiento de dimensiones nacionales que busque la transformación estructural de la sociedad peruana y, fundamentalmente, de la formación de una nueva moral de corte socialista. Con estos fines, se ha montado un amplio sistema de difusión de material periodístico y bibliográfico que es abastecido fundamentalmente con publicaciones del comunismo internacional y de los países del bloque socialista.

La comercialización de estas publicaciones en algún grado constituye una fuente de financiamiento para las actividades de propaganda que realizan las agrupaciones marxistas en el Perú.

Es importante destacar que la izquierda complementa su labor ideológica con efectivos mecanismos de promoción para afirmar su unidad por la vía práctica de la participación de la ciudadanía y el estudiantado en actividades de lucha popular.

"La prédica política evade plantearse los problemas estratégicos del Estado", por eso se ha creado el Consejo Estratégico del Estado (CEE) que actuará por encima del Consejo de Ministros, pero en absoluto secreto. Los ministros verán problemas de coyuntura y relaciones públicas.

(Redacción de Oiga)

Básicamente, la propaganda marxista se ha ejecutado en función de los siguientes objetivos de naturaleza sicológica:

- Ruptura del principio de autoridad y disciplina laboral.

- Desprestigio de las instituciones y liderazgos nacionales.

- Promoción sistemática de la división de los grupos políticos de mayor alcance nacional.

- La división y el enfrentamiento de la civilidad con la FA. 
En este avance de orden político-sicológico, las agrupaciones marxistas-leninistas han capitalizado la labor que desarrollan los grupos de la llamada 'Iglesia progresista' o 'Iglesia del Tercer Mundo'. Es más, se ha explotado con ventaja el sensacionalismo y/o tremendismo informativo de algunos medios de comunicación social que, indirectamente, hacen la apología del terrorismo y de la violencia en sus diferentes matices.

A continuación, luego de analizar las fuerzas de Sendero y el MRTA, el Servicio de Inteligencia Nacional va evaluando los cinco escenarios posibles en que pueden hallarse los acontecimientos en las siguientes fechas, en relación a la oportunidad de dar el golpe: Hasta el 20 de marzo de 1990; hasta la segunda semana del mes de mayo de 1990; hasta el 28 de julio de 1990; antes de fines de octubre de 1990, antes de fines de marzo de 1991. Termina con las conclusiones finales, anteriores al primer acto electoral.

(Nota de Redacción: En esta parte final del "plan", titulado 3. Escenarios posibles en que se encontrara el país hasta fines del mes de marzo de 1991, se describen los escenarios y coyunturas sociopolíticas, tratando de prever o adivinar el comportamiento y las reacciones de la población ante diferentes factores, circunstancias y resultados electorales, con el objeto de diseñar estrategias o escenarios y calcular posibilidades de acción para la realización del planeado golpe de estado con el que los militares pretendían apoderarse del gobierno, una vez culmine Alan García su mandato constitucional, quién, de nuevo, es visto, sin mucha fortuna, como "traidor a la patria" (sic). Por otro lado, aquí también se podrá observar un dislate más del grupo que redactó estas líneas, que repite en el apartado correspondiente al Escenario $\mathrm{N}^{0}$ 4, la misma palabra aparecida ya en la "Introducción" y en otras partes de este "Plan Verde". Se trata del término 
aprosuvbersiva (sic). Los autores de este texto no aclaran de qué exactamente se trataba esta palabreja (no falta quienes señalan que se referían al "comando Rodrigo Franco"). Los párrafos a continuación, por cierto, cuentan con el acertado comentario de la redacción de Oiga.)

3) Escenarios posibles en que se encontrará el país hasta fines del mes de marzo de 1991

a) Definición de los escenarios posibles

Se ha definido como escenarios posibles a aquellos en que la situación política, económica, social y militar presentan características definidas y presuponen un ordenamiento cualitativamente diferente, según se modifiquen la correlación de fuerzas, la actividad y las actitudes de los protagonistas.

La variación del marco económico dependerá tanto de las acciones que continúe desarrollando la actual administración del país; así como las decisiones que tenga que tomar la nueva autoridad que emerja del proceso en curso.

Las variaciones en los aspectos sociales dependerán tanto de estas acciones económicas, como del grado de movilización que la coyuntura política presupone. Los aspectos militares tendrán relación directa con la táctica a emplear en el periodo por los movimientos subversivos; así como por las decisiones políticas que puedan tomar la actual y la nueva administración del Estado; así como por el comportamiento que sigan las fuerzas paramilitares.

Son pues, escenarios cualitativamente distintos y es propósito de la misión, considerar los factores de poder y debilidad que cada uno de estos plantea en el 
momento del derrocamiento del poder civil y que la responsabilidad de la conducción de la patria recaiga en la reserva estratégica del Estado, las FFOO.

\subsection{Escenario $N^{\circ} 1$}

(Nota de Redacción: En el original de este informe se omite el punto "a" y se pasa directamente al siguiente, "b" que trata del Análisis del Escenario $N^{\circ} 1$ Preelectoral (hasta el 20 de marzo de 1990)

b) Análisis del Escenario Nº1 Preelectoral (hasta el 20 de marzo de 1990)

Este escenario presupone a los actores políticos 'democráticos' enfrascados en sus intereses de grupo y sus intereses personales compitiendo unos con otros para alcanzar su cuota de poder político y lanzando mensajes de distintos calibres a la ciudadanía con el propósito de obtener su preferencia.

Dado que 1990 será un año de profundas tensiones, no es posible prever con certeza el comportamiento de los elementos subversivos.

\subsection{Factores de poder para las FFOO}

1. Plan militar listo con requerimiento de ocho días previos para su ejecución.

2. Plan político de corto, mediano y largo plazos listo.

3. Equipos de trabajo base preparados (tomaremos los equipos de trabajo que falten del mercado, inmediatamente después de haberse ejecutado el Plan Militar).

4. Sorpresa completa: El planeamiento se ha realizado con el más completo orden y compartimentaje (sic. N. de VA). Las fuerzas enemigas no consideran posible un pronunciamiento en la coyuntura. 
5. El caos político social no ha alcanzado dinámica propia.

6. Gobierno aprista en su coyuntura más débil, sin credibilidad.

7. Países limítrofes en coyuntura de cambio de gobierno.

8. Los nuevos mandos se han asentado en sus puestos.

9. Completo apoyo del sector privado, en especial del sector exportador.

10. Represión con claro efecto preventivo de mediano plazo.

11. Se han definido nuevas tendencias políticas ajenas a las tradicionales, algunas con claro contenido patriótico.

\subsection{Factores de debilidad}

1. La Marina no está consolidada.

2. El nuevo Comando no está totalmente coordinado.

3. Sectores de la oficialidad comprometidos desmoralizados por falta de resolución a fines de 1989.

4. Irremediablemente estallara la economía en manos del gobierno emergente de las FFOO.

5. Grupos subversivos no han demostrado aun todo su poder político-militar.

6. Sectores políticos se activan y se organizan para la coyuntura.

"Relación con los medios de comunicación: El objetivo mínimo por alcanzar con este sector debe consistir en conseguir la AUTOCENSURA" dejándoles entrever nuestra decisión de ir hasta las últimas consecuencias en el logro de nuestros objetivos de Reconstrucción Nacional".

(Redacción de Oiga)

\subsection{Escenario $N^{\circ} 2$}


(Nota de Redacción: En este acápite, en el original del informe se ha omitido los puntos "a" y "b", pasando directamente al punto "c" dedicado a Análisis del Escenario Electoral $N^{\circ}$ 2. Primera vuelta (hasta la segunda semana del mes de mayo de 1990)

c) Análisis del Escenario Electoral $N^{\circ}$ 2. Primera vuelta (hasta la segunda semana del mes de mayo de 1990)

Evolución probable de los acontecimientos; desde el punto de vista del accionar de la subversión; las municipales de 1989 establecieron la pauta de lo que será el proceso presidencial y renovación del Legislativo.

Sin embargo, ante la casi certeza de que el proceso electoral presupone dos vueltas, la dinámica subversiva podría caracterizarse por dos tiempos, siendo el primero un amague y el segundo llevar la lucha armada a un plano superior.

Esta posibilidad debe encuadrarse en el hecho de que gran parte del armamento en poder de los subversivos no ha sido empleado aun y la coyuntura podría ser la adecuada para una demostración de poder.

La proliferación de candidatos y su dispersión geográfica facilitaría los asesinatos selectivos.

Es necesario pensar en una escalada de violencia, el probable resultado electoral sería el siguiente: Fredemo 40/45\%, blancos, nulos y viciados 15/25\%, IS (Barrantes) 12/15\%, IU 12/15\%, Apra 10/15\%.

De realizarse el ataque en este escenario los factores de poder serian: 
1. Las fuerzas políticas desplazadas en la primera vuelta asumirían una postura hacia la pasividad relativa al quedar definida su participación en el cuadro político y ver frustradas su máxima expectativa.

2. La frustración del Fredemo de ganar en primera vuelta abriría un compas de espera, desaliento, expectativa y tensión en los sectores sociales de clase media y alta que le son proclives.

3. El escenario quedara aclarado, pero sin un mandato definido.

4. Grupos subversivos empezaran a mostrar su verdadera fuerza relativa.

5. Nuevo Comando con alto grado de coordinación.

6. Consolidación de la oficialidad en las diferentes armas.

\subsection{Factores de debilidad}

Expectativa y actividad política in crescendo.

Expectativa definida en los sectores que quedan en carrera.

Se aleja la posibilidad de que el pronunciamiento quede focalizado contra el partido gobernante y el espectro político en carrera se sienta directamente agredido.

Sectores políticos patrióticos pueden quedar minimizados electoralmente.

La actividad político-social puede ir adquiriendo dinámica propia.

Se exacerbara el conflicto social. 
Desmoralización de sectores de las FFOO sobre una conducción directa del Estado y tendencia a tomar simpatía dentro de las alternativas.

Intento de seducción y neutralización de los mandos de las FFOO por parte de los actores políticos con expectativas.

La economía estallará siempre en las manos de las FFOO.

\subsection{Escenario $N^{\circ} 3$}

(Nota de Redacción: Como ha venido sucediendo en anteriores segmentos de este informe, en este acápite se ha omitido los puntos "a", "b" y "c", para pasar directamente al acápite "d", dedicado como se verá al Análisis del escenario electoral $N^{\circ} 3$ Segunda vuelta (Hasta el 28 de julio de 1990) -ignoramos si tales "omisiones" son deliberadas, pero es notoria la frecuencia de tales "faltas" y "discontinuidades" en el original de este documento - )

d) Análisis del escenario electoral Nº 3 Segunda vuelta (Hasta el 28 de julio de 1990)

Evolución probable de los acontecimientos: la fecha de la segunda vuelta no está definida y es posible esperar que el gobierno aprista influya en el momento de su realización y es presumible que alargue el momento hasta el mes de junio de 1990.

Es previsible una intervención descarada y manipuladora del gobierno en contra de la candidatura del Fredemo usando los medios y recursos del Estado; así como el aparato partidario en apoyo de la segunda alternativa; sin descartar que el grado de convulsión política de la primera vuelta le permita al gobierno aprista maniobrar para mantenerse en el poder, aunque el grado de deterioro de la situación económica 
parecería hacer desistir incluso a AGP de esa posibilidad; la victoria del Fredemo sería un escenario y la victoria del segundo la variante.

Antes de llevarse a cabo esta segunda vuelta la subversión habrá intentado alcanzar su máxima expresión destructiva asestando golpes en energía, transporte, asesinatos selectivos, incluso la posibilidad de copar algunas ciudades o localidades con alto contenido político (objetivos posibles: bloqueo y corte de la carretera Central y FFCC con carácter semipermanente; destrucción de una hidroeléctrica clave, copamiento y/o aniquilamiento de unidades militares acuarteladas; atentados espectaculares con gran pérdida de vidas, enfrentamientos armados urbanos en acciones simultaneas con búsqueda de resonancia internacional).

\subsection{Factores de poder}

1. Alto nivel de violencia política que incremente la conciencia de inviabilidad democrática para hacer frente a la subversión.

2. Conciencia creciente a nivel de fuerzas políticas sobre la necesidad de la intervención de las FFOO ante las bajas sufridas en sus propias filas.

3. Grupos subversivos mostrando su verdadera capacidad de combate.

\subsection{Factores de debilidad}

1. Alternativa en la conducción política del Estado elegida según el método convencional.

2. Posibilidad de intervención y/o presión extranjera para que se respete el gobierno elegido.

3. El sector político elegido puede considerar el pronunciamiento motivado por el propósito de violentar sus derechos legítimamente adquiridos. 


\begin{abstract}
4. Actividad político-social con dinámica propia.
5. Neutralización de la opinión al interior de las FFOO.

6. Iniciar la conducción del Estado con el grado máximo de anemia económica.

7. Colapso del sector Energía y Transporte.
\end{abstract}

\title{
3.3.2.7.4. Escenario $\mathrm{N}^{\circ} 4$
}

(Nota de Redacción: Una vez más se presenta una manifiesta incoherencia o discontinuidad en cuanto a los ítems o rubros temáticos de un subcapítulo, como en este caso, en que se ha omitido los acápites "a", "b", "c" y "d" para pasar directamente al acápite "e" que trata del Análisis del escenario № 4. Estallido económico (Antes de fines del mes de octubre de 1990)

e) Análisis del escenario $\mathrm{N}^{\circ}$ 4. Estallido económico (Antes de fines del mes de octubre de 1990)

Evolución probable de los acontecimientos: Los intentos de corrección de la actividad económica estarán acompañados de actores político-sociales movilizados por la actividad política y la gravedad de la situación, la conducción política del Estado intentara emplear a las FFOO en el control de la población con criterios potencialmente ambivalentes, intentando evadir la responsabilidad de la represión, descargándola en las FFOO.

\subsection{Factores de poder}

1. Definitivamente este escenario es el que presenta las mínimas ventajas.

\subsection{Factores de debilidad}


1. Nueva conducción de la política del Estado con el máximo nivel de respaldo político interno y externo.

2. Carácter legitimo de la conducción del Estado con el actual partido gobernante fuera del papel protagónico, diluyéndose crecientemente su responsabilidad en el desastre ejecutado.

3. Presiones y demandas sociales en fase de agudización.

4. Desmoralización de nuestras propias fuerzas.

5. Cambio de mando o mediatización parcial de los mismos.

6. Expectativas favorables de amplios sectores de la población ante la supuesta oportunidad que significa la nueva dirección política del país.

7. Débil tregua social de amplios sectores a la nueva conducción política.

\subsection{Escenario $N^{\circ} 5$}

(Nota de Redacción: Como ya se nos está acostumbrando, en el original de este informe, en este punto, se ha omitido los acápites "a", "b", "c", "d" y "e", para dar paso al punto signado con la letra "f" que trata sobre el Análisis del escenario $\mathrm{N}^{\circ} 5$. Desarticulación organizativa (Antes de fines del mes de marzo de 1991)

f) Análisis del escenario $N^{\circ} 5$. Desarticulación organizativa (Antes de fines del mes de marzo de 1991)

Evolución probable de los acontecimientos: El efecto del daño causado por la administración aprista se hará sentir en la vida cotidiana de amplios sectores de la población en este periodo, al existir un fenómeno acumulativo en los fenómenos económico-sociales; las correcciones hipotéticas en la nueva administración civil del Estado que se pusieran en práctica no serán capaces de revertir la situación en el 
corto plazo; la situación entrara más bien en su fase aguda, con fuertes tentaciones por las presiones políticas de abandonar cualquier posible disciplina fiscal, sin dejar de lado las presiones potenciales de grupos económicos laborales, en ningún caso podemos pensar en una situación ordenada o equilibrada.

\subsection{Factores de poder}

1. Sera el grado de dinámica propia que alcance la convulsión social la que establezca la ventaja relativa de este escenario.

2. El estallido económico y el manejo de la situación no habrá estado en manos de las FFOO.

"Los grupos subversivos, fuertemente golpeados y debilitados en los últimos meses es junio de 1990 - podrían recibir un golpe demoledor con una poderosa represión en los primeros 90 días, efecto que podría tener un alto valor estratégico-político". (Redacción de Oiga)

3. Es previsible un rápido apoyo de la población a la nueva administración.

4. Volverá a tornarse evidente que las soluciones de fondo solo podrán manejarse desde una perspectiva de fuerza.

\subsection{Factores de debilidad}

1. Es posible prever une desarticulación de los mandos de puestos claves.

2. El régimen de relevo cuenta con suficiente apoyo político externo.

3. El frente interno aun tiene sectores económico-sociales que respaldan el gobierno civil. 
4. Las FFOO pueden encontrarse coyunturalmente comprometidas a mantener el orden interno de tal manera que escaseen las energías para destacar recursos humanos suficientes para la conducción política.

5. Grupos de trabajo que aun se encuentran movilizados puedan encontrarse desperdigados, desmoralizados y sin coherencia organizativa ante la prolongada falta de resolución que se hubiera manifestado.

\subsection{4. Conclusiones}

(Nota de Redacción: En este acápite 4. Conclusiones, el lector encontrará otra vez el espeluznante término excedente poblacional, aderezada como una frase, es decir: ...excedente poblacional nocivo y se soslaya la necesidad de aplicar la pena capital a los enemigos de la patria y a los sectores irrecuperables., esto es... se trataba de una de las políticas de Estado que Alberto Fujimori y sus acólitos, influenciados por los lineamientos de este siniestro "plan de gobierno secreto", pretendía implantar en el Perú. Resulta sintomático constatar que la aludida frase, excedente poblacional, esté desparramada en varias partes de este "Plan Verde" y, cómo no, íntimamente ligada a los operativos militares y de otra índole destinados a cumplir a rajatabla con los objetivos planteados en este texto. Finalmente, hay que señalar otra incongruencia del texto de este "plan": la referencia al número "4" que aparece en cursiva delante de "Conclusiones" no tiene sus correlaciones "1", "2" y "3" en el texto original.)

a) El hipotético cambio de administración civil en el país constituye una fase superior en el proceso de ruptura en el que se encuentra la sociedad peruana, sin planeamiento estratégico y sin posibilidad de colocar al Perú en el siglo XXI con opción a transformarse en sociedad moderna. 
b) La prédica política evade el plantearse los problemas estratégicos del Estado peruano oscilando en enfoques simplistas de estatismo versus propiedad privada, mucha burocracia o poca burocracia.

c) Se carece de planteamientos sobre política poblacional, sobre tratamiento correcto del excedente poblacional nocivo y se soslaya la necesidad de aplicar la pena capital a los enemigos de la patria y a los sectores irrecuperables.

d) Esta apreciación de Inteligencia parte de que la "necesidad histórica existe y que la defensa de la patria lo exige, ilustrando al Comando sobre las coyunturas posibles para iniciar las hostilidades contra la experiencia aprosubversiva impulsando su erradicación definitiva."

e) El derrocamiento del gobierno civil supone una operación militar de gran alcance, en el que el enemigo estaría conformado no solo por el partido político que será desplazado del poder, sino también por las fuerzas controladas por la izquierda e incluso por la resistencia que opondría el liderazgo de agrupaciones conservadoras.

f) El costo social tendría tres componentes:

1. El inherente a las operaciones del pronunciamiento.

2. El que se producirá en la guerra con los grupos subversivos.

3. El costo de recomponer la actual coyuntura económica, moral y terminar con el proceso delincuencial que asola al país.

g) Es necesario precisar que este costo en ningún caso será mayor que el que se pagara continuando con el statu quo e intenciones de cambio en régimen democrático sin perspectiva estratégica "(Proyecto Nacional)", podríamos definir esto como la administración de la guerra civil. 
h) Sera necesario la implantación del estado de emergencia en todo el territorio nacional.

I) El abastecimiento de artículos de primera necesidad y combustibles en los días posteriores al pronunciamiento merecerán una especial atención.

j) El aislamiento diplomático inicial del nuevo gobierno militar es inevitable. Es necesario prever acciones de gran impacto internacional contempladas en el plan político (rompimiento de relaciones con la República Popular de China, reconocimiento del gobierno de Taiwán, tema narcotráfico USA-Europa, contactos políticos USA-Europa, campaña sicológica internacional).

k) "Es necesario contemplar entre los primeros actos del gobierno militar el derogar la Constitución Política del país, hecho que debe significar encuadrar al gobierno dentro de un nuevo marco legal y facilite la adhesión creciente de elementos civiles."

1) Es necesario contar con unidades amigas en la I y III regiones, Fuerza Aérea y Marina, que sirvan de soporte a partir del cual se plieguen al pronunciamiento la mayoría de elementos, debiendo preverse una acción sicológica para los indecisos y aquellos que pretendan ponerse en contra.

11) Al interior del país es necesario que la acción militar cuente con el apoyo de una campaña sicológica agresiva desde el inicio de las operaciones "(empleo máximo de comunicaciones nacionales)." 
m) Es necesario ponderar adecuadamente en el análisis de los escenarios la importancia de acortar el sufrimiento de la población debido al dilata miento excesivo de la situación de caos actual.

\section{4. Últimas Evaluaciones}

Al producirse los primeros resultados electorales del 8 de abril de 1990, el Servicio de Inteligencia comienza a confeccionar añadidos a su 'apreciación'.

A la sorpresa del segundo lugar en la elección presidencial para el casi desconocido Fujimori se une el desmoronamiento del candidato del Fredemo y la incertidumbre que esta situación ha abierto para el futuro próximo.

El SIN comenta:

"Ha quedado configurado un golpe electoral que compromete a los partidos políticos y al gobierno".

"El gobierno y el Apra han visto alterada su estrategia al no pasar a la segunda vuelta".

"El Fredemo sufrió una derrota significativa al no haber obtenido un mandato claro"... "Su candidato ha manifestado un estado de ánimo perdedor".

"El gobierno insiste en su posición irresponsable en la conducción del país".

"Las izquierdas fueron pulverizadas electoralmente". 
"Preocupa a Alan García dejar el gobierno e incluso se habla de la gestación de un autogolpe".

"Palacio apoya la candidatura Fujimori".

Luego resalta el SIN que los movimientos subversivos no pudieron impedir el proceso electoral y no lograron orientar al electorado hacia el voto en blanco o viciado. Sin embargo, cree que los grupos subversivos pueden recuperarse de su fracaso. Considera además que el comportamiento subversivo se ha desenvuelto dentro de los lineamientos esbozados en la apreciación previa.

"La coyuntura -agrega- ha permitido impulsar el entrenamiento de la fuerza -la conspiración- dentro del marco del DIT". "En las últimas semanas se han podido actualizar planes". "El personal operativo ha tenido intenso trabajo". "No se percibe en el Alto Mando preocupación por la participación de las FFAA en la conducción política del país, que es inevitable". "Continua el problema en la FAP y se tiene información de que el ministerio de Defensa se estaría prestando al autogolpe de Alan García".

Y anota, entre otras cosas, estas dos preocupaciones: "Cambio 90 no es más que una corriente de opinión, no fue capaz siquiera de inscribir candidatos en diez departamentos", "La renuncia de cualquiera de los dos candidatos configuraría un problema de orden legal constitucional".

Sus conclusiones son que "los grupos de poder económico (integrantes del Fredemo), ante la configuración de su derrota, buscaran inexorablemente el concurso de las FFAA", ya que "a la debacle económica se agrega la perspectiva de la anarquía política". 
"El alto mando naval muestra desconfianza al liderazgo del Ejercito, ante la posibilidad de un autogolpe de Palacio".

"Este es el momento de mayor parálisis y falta de reflejos en el escenario político". "Un pronunciamiento después de la segunda vuelta electoral constituye ir en contra de una esperanza de cambio ya configurada... los estratos de menores niveles económicos verían que la irrupción de las FFAA es en favor de los ricos".

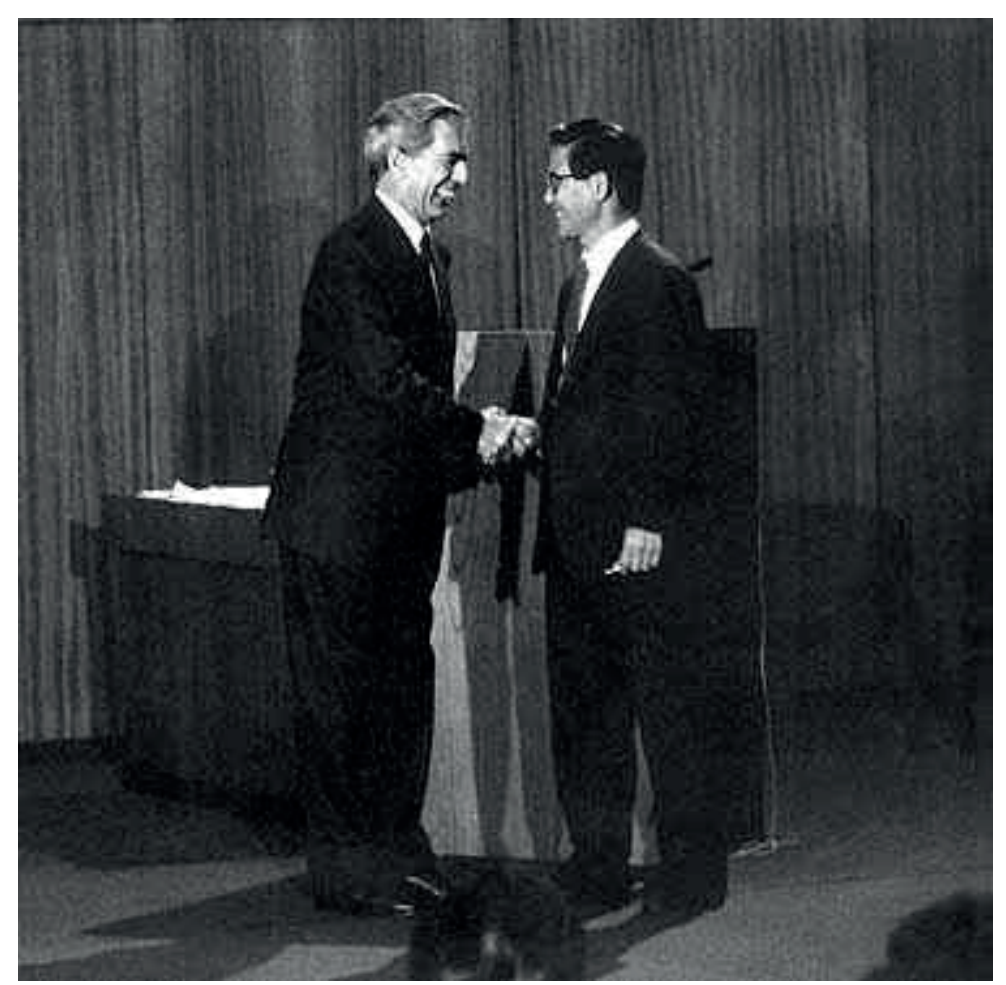

Figura22a. Saludo protocolar. Un maquillado Fujimori y un sonriente pero cansado Vargas Llosa se saludan tras el histórico debate televisivo previo a la segunda vuelta de las Elecciones Presidenciales de 1990. Tras la derrota del candidato-escritor, el SIN se expresaría a través del "Plan Verde" con frases como estas: "El golpe electoral del 8 de abril ha quedado consolidado con el resultado del 10 de junio". "Los partidos políticos han sido rechazados en su totalidad". "La derrota de Vargas Llosa y su alejamiento del país han configurado un vacío de liderazgo en importantes sectores 
económicos y sociales". Sintomático: esperaban la derrota del Fredemo (ver líneas debajo de esta leyenda).

Foto del reportaje "Anatomía de un debate" publicado en la revista Caretas el 17 de mayo de 2001.

\subsection{Apreciación al 13 de junio del 90}

"Nos encontramos en el Escenario $\mathrm{N}^{\circ} 3$, periodos $\mathrm{N}^{\circ} 2$ y 3 de la apreciación de inteligencia estratégica del 20 de febrero de 1990. El resultado oficial de la segunda vuelta era la diferencia entre el periodo $\mathrm{N}^{\circ} 2$ y 3 . Dado el desplome de nuestra principal dificultad (Fredemo) dicha diferencia desaparece".

"El golpe electoral del 8 de abril ha quedado consolidado con el resultado del 10 de junio". "Los partidos políticos han sido rechazados en su totalidad". "La derrota de Vargas Llosa y su alejamiento del país han configurado un vacío de liderazgo en importantes sectores económicos y sociales".

"Los índices delincuenciales son alarmantes y de igual magnitud nociva que la de los grupos subversivos".

"Algunos comandos de las FFAA desde hace tres semanas son motivo de especial control por parte de Palacio".

"Las FFAA se encuentran con sus planes de operaciones terminados y de alguna manera puestos en práctica en el proceso electoral, excepto algunas variantes". "El liderazgo de las FFAA está definido". "No se ha realizado ningún contacto con la Policía Nacional". 


\subsection{Análisis}

"Dado que no podemos esperar nada seguro de Cambio 90 y la patria no está para más experimentos económicos y dado que nos encontramos 'listos', ningún escenario debe ser descartado. El escenario $\mathrm{N}^{\circ} 3$ sigue vigente de análisis. Hay que reconocer que el esperar al 10 de junio fue un éxito, dado el resultado electoral".

"Nos encontramos en una coyuntura de máxima acumulación de fuerzas amigas en las FFAA como para empeñar la lucha en condiciones optimas". "La coyuntura estratégica es inmejorable en la consecución de los objetivos nacionales de largo plazo". "Vargas Llosa perdió el liderazgo político, vacio que puede ser llenado fácilmente por la Junta de Gobierno". "Hoy podemos reorganizar bajo nuestras banderas a las fuerzas dispersas del Fredemo, que son la mayoría cualitativa del país, mañana quién sabe".

Y resaltan enseguida estas anotaciones:

"Los grupos subversivos, fuertemente golpeados y debilitados en los últimos meses podrían recibir un golpe demoledor con una poderosa represión de los primeros 90 días de la Junta de Gobierno, efecto que podría tener un alto valor estratégico impulsando la política de pacificación".

(Nota de Redacción: En la versión original del informe contenido en el presente reportaje de Oiga se omiten los acápites 1 al 6, por lo que se prosigue con el \# 7)

7. La pérdida de espacio político nacional y el periodo de reorganización en que se orientaran las izquierdas las encuentra relativamente desarticuladas. 
8. El ajuste de cuentas a García representa un capital político considerable.

9. Cualitativamente hablando la sensación de pavor que se presenta al sector lucido de la población es superior a la fuerza que puede representar un movimiento que no pudo presentar candidatos en diez de los veinticuatro departamentos y que seleccionó mal en los otros catorce que consiguió y que hace noventa días era desconocido en la escena nacional.

10. Es posible actuar antes de que se configure un fenómeno de anemia aguda (fase de descomposición social crítica).

11. No hay un resultado formal del proceso electoral ni hay un nuevo gobierno recién instalado.

12. La población se encuentra desmovilizada políticamente debido al mundial de futbol.

"Es el momento de negociar la conducción política del Estado en una solución cívicomilitar dentro del concepto de 'democracia dirigida' que ha sido elaborado". (Redacción de Oiga)

\subsubsection{Factores de debilidad}

1. No controlamos la Policía Nacional.

2. El Apra representa una fuerza considerable.

3. El ajuste económico tendrá que hacerse bajo la conducción de las FFAA.

\subsubsection{Consideraciones finales}


1. La fase de 'prudencia y acumulación de fuerzas' ha concluido y podemos pasar a una fase de resolución.

2. La confrontación político-electoral ha permitido nuclear reservas intelectuales que hoy están disponibles, pero que entrarán en un proceso de dispersión.

3. Dentro o fuera del gobierno las FFAA no podrán estar al margen de los efectos del ajuste económico.

4. Si no tomamos una decisión rápida y preventiva correremos el riesgo de que cuando tomemos el gobierno solo nos quedará pasar "de los reductos a Julcamarca" y jugarnos el destino en una tempestad.

\subsubsection{Se fija el día $\mathrm{D}$ hora $\mathrm{H}$ y se plantea negociar con Fujimori}

Las anteriores "consideraciones finales" no resultan del todo finales. Les sigue una 'Hoja de coordinación final' donde se indica que el 'detonante', el argumento de justificación al golpe es la 'situación de traición a la patria, configurada por la vergonzosa liberación de medio centenar de elementos subversivos (MRTA) por parte del gobierno de García Pérez..."

\subsubsection{Fecha del día $D$}

27 de julio de 1990

\subsubsection{Criterio de selección}

Es el momento en que el poder de García Pérez se encuentra minimizado y Fujimori no ha tomado posesión del cargo permitiéndole así a las FFAA negociar la conducción política del Estado en una solución cívico-militar dentro del concepto de 
'democracia dirigida' que se ha elaborado para hacer frente a las necesidades de la patria.

\subsubsection{1. "Secuencia del día $D$}

1. Ejecución del plan militar.

2. Pronunciamiento: Comunicado $\mathrm{N}^{\circ} 1$

Contenido: Pronunciamiento contra García de acuerdo al detonante para entregar el gobierno al presidente electo Fujimori haciendo ver que las FFAA no tienen ambición de gobernar.

3. Negociación y acuerdo con Fujimori.

Bases de negociación, concepto de 'democracia dirigida'.

a. Inminencia de que las FFAA y el gobierno de la República caigan en manos de Fernández Dávila - García Pérez en el verano de 1991.

b. Solución del país en el largo plazo resolviendo los problemas estratégicos del Estado.

c. Imposibilidad práctica de solución a la crisis del Perú después del entrampamiento legal que el traidor García Pérez ha producido y la atomización del Congreso, lo que hace necesario su receso transitorio.

d. Garantía y estabilidad a los agentes económicos con el respaldo de las FFAA (economía de mercado)

e. Política de pacificación coherente, planeada y dirigida por las FFAA.

f. Moralización, juzgamiento por traición a la patria a García Pérez y jerarcas del régimen aprista (tribunal militar).

g. Depuración moral en las FFAA.

h. Posicionamiento de las FFAA en el primer periodo de 'democracia dirigida'. 
De no arribarse a un acuerdo con Fujimori nos moveremos en el escenario $\mathrm{N}^{\circ} 2 . "$

\section{"Comunicado $\mathrm{N}^{\circ} 2$}

Contenido: Haciendo conocer que el presidente electo no acepta la política de pacificación, moralización y solución a la crisis económica planteada por las FFAA y reconoce no estar preparado para la conducción del país en su actual estado de destrucción en que el traidor a la patria García Pérez lo ha dejado y entrega a las FFAA la responsabilidad del Estado.

4. Pronunciamiento de las FFAA.

Nota:

Todos estos eventos deben producirse entre el día 'D' hasta hora 'H' más 24 horas."

\subsection{En el próximo número}

Los preocupantes anexos

Con la insistente precisión de que es necesaria la pena de muerte como instrumento de disuasión y de disciplina y con la descripción del sistema de gobierno que se había planeado, ya con el título de 'Reconstrucción Nacional', un Consejo Estratégico de Estado (CEE) que estaría, secretamente por encima de un Consejo de Ministros disminuido. Consejo que junto al jefe de Estado, debía mantenerse en el poder por tiempo indefinido.

(Nota de Redacción: En la segunda parte del documento (que Oiga anuncia en su previo \# 647), pasamos a detallar el siniestro contenido de Los 'Anexos' del golpe de 
Fujimori. El lector se dará cuenta que la redacción de lo que sigue a continuación mejora los planteamientos de la primera parte, y ya se habla aquí del Poder en la sombra, como se llama esta segunda parte del "Plan Verde", donde se menciona la implantación en el Perú de una dictadura autoritaria, tipo Gestapo, es decir, policial, con una falsa careta de "democracia", esto es, aquí lo que impera es una democracia guiada donde nada queda al azar de los designios del "chino". Oiga abre la continuidad de este informe con una suerte de introducción donde analiza la coyuntura política tras la victoria electoral de Fujimori de 1990, y recuerda cómo fue que se diseñó el proyecto de gobierno y describe los nuevos lineamientos del régimen cívico militar fujimorista.)

\section{El "Plan" que trajo un pajarillo verde... $2^{\mathrm{a}}$ Parte}

6.- ¿El Sistema Nacional de Control, Seguridad y Propaganda que se plantea es el equivalente a una 'GESTAPO'?

R.- Sí, definitivamente.

22.- ¿El Gobierno Militar estaría dejando la conducción del Estado a los civiles?

R.- No, quien decide por donde debe ir el vehículo (Estado) para legar a los objetivos nacionales de largo plazo es las FF.AA. que emplea los mejores choferes (civiles) para manejar dicho vehículo. 
$(\ldots)$

Fragmento del texto de Los 'Anexos' del golpe de Fujimori. Oiga, 19/7/93 (Nota 15)

(Reportaje publicado por Oiga el 19 de julio de 1993) (Nota 14)

\subsection{Los 'Anexos' del golpe de Fujimori}

\subsubsection{El Poder en la sombra}

En el número anterior de OIGA aparecieron resúmenes salteados de un desconocido plan de gobierno, actualmente en ejecución por Fujimori y elaborado a mediados del año ochenta y nueve por un equipo de la Fuerza Armada que, al parecer, según recientes averiguaciones, no era auspiciado, por ninguno de los mandos militares de aquel entonces.

-Sabíamos que andaban reunidos unos cuantos oficiales, proyectando ciertas inquietudes - nos dice un divisionario de esos años, pero no se les dio importancia porque no contaban con mando de tropa. No tenían poder efectivo y lo que hacían no pasaba del campo intelectual.

En otras fuentes corre el ritmo de que el equipo estaba compuesto por elementos del Ejército, la Marina y la Aviación. Y hay quien, haciendo memoria, cree recordar que entre los inquietos podrían haber estado los militares Mauricio, Rengifo y Valdivia; los marinos Montes Lecaros, Polar y Hesse; y los aviadores Gonzalo y Moro. Mientras que otros añaden al marino y la mayoría menciona al general Mayaute Guezzi, actual director de Planes y Operaciones del Comando General del Ejército. A 
OIGA -insistimos - no le consta que los nombrados hayan formado parte del complot. En esta edición, al igual que en la última, damos cuenta de rumores que circulan en medios bien enterados de los ambientes militares o enumeramos los cargos de los altos mandos del momento sin asegurar qué actuación cumplieron en relación a los hechos que revelan los documentos del pajarillo verde.

Sin embargo, de la lectura cuidadosa de los capítulos sectoriales, se hace evidente que no solo militares había en el complot. Es notoria, y debió ser numerosa, la presencia de elementos civiles especializados sea en salud, en pesca, en energía, en educación o en economía. Lo que hace sospechar, dado el carácter reservadísimo del trabajo, que estos elementos civiles debían pertenecer al CAEM (Nota 17) o al Servicio de inteligencia, donde ya operaba, como oculto asesor del general Edwin (Cucharita) Díaz, el ex capitán y abogado Vladimiro Montesinos.

¿Quiénes son esos civiles del CAEM o el SIN? Aquí la imaginación se dispara revisando los cuadros de las diferentes promociones del Centro de Estudios que fundó el general Marín y la atención se fija entre los ex alumnos que quedaron ligados a la institución después de concluidos sus cursos. Habría que indagar, se dice, entre aquellos nombres que figuraron y figuran en las notas periodísticas de actualidad.

Pero no son las personas -en verdad aún no identificadas por nosotros -lo que más importa de este plan de gobierno que un pajarillo verde de alta graduación puso en manos de OIGA. Lo importante es la orientación del documento, sus motivaciones, sus perspectivas y la luz que arroja sobre los últimos acontecimientos del quehacer político nacional. 
Los despropósitos del régimen de Alan García, cada día más delirantes, y el complejo de culpa que dejó en la Fuerza Armada el fracaso de la 'revolución' militar de los años setenta, fueron las motivaciones inmediatas que tuvieron estos secretos conspiradores del ochenta y nueve. Su ánimo era corregir errores, encontrar nuevos rumbos para borrar el pasado. Claro que, como siempre, el nuevo rumbo no se buscó en un paciente perfeccionamiento de la democracia, el mejor y más seguro modelo de desarrollo, sino que se cayó en la acostumbrada tentación totalitaria, en un régimen autoritario. Todo quedó reducido a copiar un modelo de moda y, además, el más cercano; en este caso Pinochet y Chile. De ahí surge la Democracia Dirigida, el gobierno civil-militar y la economía de mercado. Que son los lineamientos generales del programa de gobierno que OIGA ha revelado al público, y que coincide con la actuación del régimen fujimorista. Aunque no dejen de destacar varios acertadísimos análisis de los problemas peruanos y no pocos planteamientos, de extremada lucidez, sin que falten novedosas variaciones de los tradicionales puntos de vista militares.

Con el plan a la vista y sabiendo por "Apreciaciones" de Inteligencia, también publicadas en OIGA, que la aceptación del programa militar fue la condición impuesta a Fujimori para acceder a la presidencia, es fácil ahora explicarse muchos de los misterios del fujimorismo. Entre ellos sus audacísimos arreglos fronterizos y la resolución que tuvo Fujimori de viajar a Quito con un ramo de olivo en la mano y dispuesto a no alterarse por las referencias ecuatorianas al "conflicto de límites". Paso que ningún presidente peruano se hubiera atrevido a dar en el pasado. Hasta ayer, militares y civiles coincidían en unir espacio territorial con problema fronterizo. Y ¡ay! del civil que se atreviera a transgredir este dogma. Las sagradas fuerzas tutelares de la patria le habrían caído encima, excomulgándolo de por vida.

(Nota de Redacción: El contenido de la primera parte del "Plan Verde", con los correspondientes análisis de la revista Oiga, suscitó no pocas y airadas reacciones por 
parte de algunos personajes sindicados como los "autores" de este informe, como el que sigue a continuación: el general 'Cucharita' Díaz, de tan desafortunada actuación durante el régimen fujimorista, quien, al parecer, se cruzó de chicotes... y entró en contradicciones en esta carta que dirigió al director de Oiga.)

Recuadro 01 (Cuadro del documento: Los 'Anexos' del golpe de Fujimori)

\subsection{El Gral. Díaz quiere enredar las cosas y revela que hubo un golpe fallido el 29 de julio del 90}

Demostrando ser un calificado oficial de Inteligencia, el general Edwin Díaz, a quien cariñosamente, sus amigos le llaman 'Cucharita', no envía una carta sin desperdicio alguno.

Comienza por insinuar que el documento publicado por OIGA "podría ser una especie de estudio de Estado Mayor". No lo niega, lo que hace es deslizar la puntería hacia otro blanco, escogido con malicia. Mientras él resulta la pobre víctima de una "sistemática campaña por hechos y acciones totalmente ajenos" a su persona. Afirma que él no pudo ser autor de esos textos porque sus concepciones y las del SIN eran por completo diferentes a las de los documentos publicados. Algo más que evidente, pues habría que ser en exceso inocente para creer que los documentos oficiales del SIN y las opiniones públicas del general Díaz en esos días podrían parecerse a las apreciaciones de los documentos que se comentan. Con un mínimo de malicia es de sospechar que, contrariando sus actividades oficiales, una mano izquierda del SIN fue la que los estuvo elaborando. $\mathrm{O}$ ¿para qué trataba de entrevistarse en aquellos días el general Días con el candidato Vargas Llosa? ¿Para darle a conocer sus constitucionalistas concepciones oficiales?... (Esa entrevista no se produjo porque a 
quien esto escribe le olía mal el encuentro y no atendió las insistentes solicitudes del asesor del jefe del SIN).

Pero toda la carta apunta a insinuar que sí hubo en aquel entonces un intento de golpe y que éste se produjo en 29 de julio del 90, horas antes del desfile de Fiestas Patrias. Hace así referencia, con maliciosa puntería, a sucesos que se produjeron después del acuerdo de las FF.AA. con Fujimori y en los que habría tenido participación el general Jaime Salinas Sedó. Correspondería a este oficial responder desde la cárcel donde sus convicciones democráticas y el abuso del poder lo tienen recluido, las mañosas referencias del ayer hábil ex-jefe del SIN y hoy militar en retiro aunque, al parecer, político en actividad.

Leamos, a continuación, íntegra la carta del general Edwin (Cucharita) Díaz. F. Igartua

Lima, 15 de julio de 1993

Señor Francisco Igartua

Director del Semanario OIGA

Presente.-

De mi consideración:

La revista OIGA No. 647 del 12 de julio de 1993, en sus páginas 20 a 35, publica bajo el título "HISTORIA DE UNA TRAICIÓN", una serie de extractos de un documento que podría ser una especie de "estudio de Estado Mayor" para subvertir el orden constitucional. Como la revista OIGA, sin ningún fundamento, me endilga a mí y al 
Servicio de Inteligencia Nacional la autoría de estos documentos, me veo en la obligación de precisar lo siguiente:

1. Que, existe una campaña sistemática para involucrarme en hechos y acciones a las cuales soy totalmente ajeno como persona y como ex-jefe del Servicio de Inteligencia Nacional.

2. Que, en relación a las publicaciones realizadas por OIGA de supuestas apreciaciones de Inteligencia y planes militares conspirativos, elaborados entre 1989 y 1991, debo decir enfáticamente que NO SON DOCUMENTOS ELABORADOS POR EL SIN. Nunca podrían serlo, porque sus concepciones distan totalmente de la Política y Criterios de Inteligencia dados al Sistema durante mi gestión. Definitivamente, otras eran nuestras conclusiones frente a la proyección política y económica del país, frente a la lucha contra el terrorismo subversivo y el narcotráfico, de nuestras relaciones internacionales y de los desajustes sociales en educación, justicia, salud y trabajo.

3. Que, mi desempeño en el cargo de jefe del SIN -ostentado hasta el mes de enero de 1991 - siempre estuvo enmarcado dentro de la norma constitucional, la ley y la función de asesoramiento a la Presidencia de la República, como primera institución de la Nación, justamente, por esa línea seguida se pudo controlar los arrestos "golpistas" del 29 de julio de 1990, cuando, con criterios como los propuestos en las publicaciones de OIGA, se pretendió impedir el ascenso constitucional del ingeniero Fujimori al poder.

4. Finalmente, debo reiterar, en forma terminante, que los documentos publicados por la Revista OIGA No. 647 NUNCA HAN SIDO PROCESADOS EN EL SERVICIO DE INTELIGENCIA NACIONAL, menos difundidos por los canales de rigor; $y$, en 
mi condición de militar, sostener que tampoco pueden comprometer al Ejército Peruano, más aún cuando en el referido periodo 1989-1991, que enmarcó el proceso electoral, mantuve muy en alto su disciplina y su rol constitucional.

Agradeciendo la publicación de la presente, quedo de Ud.

Atentamente.

Edwin Díaz Zevallos

Gral. Div. (r) Ejército Peruano

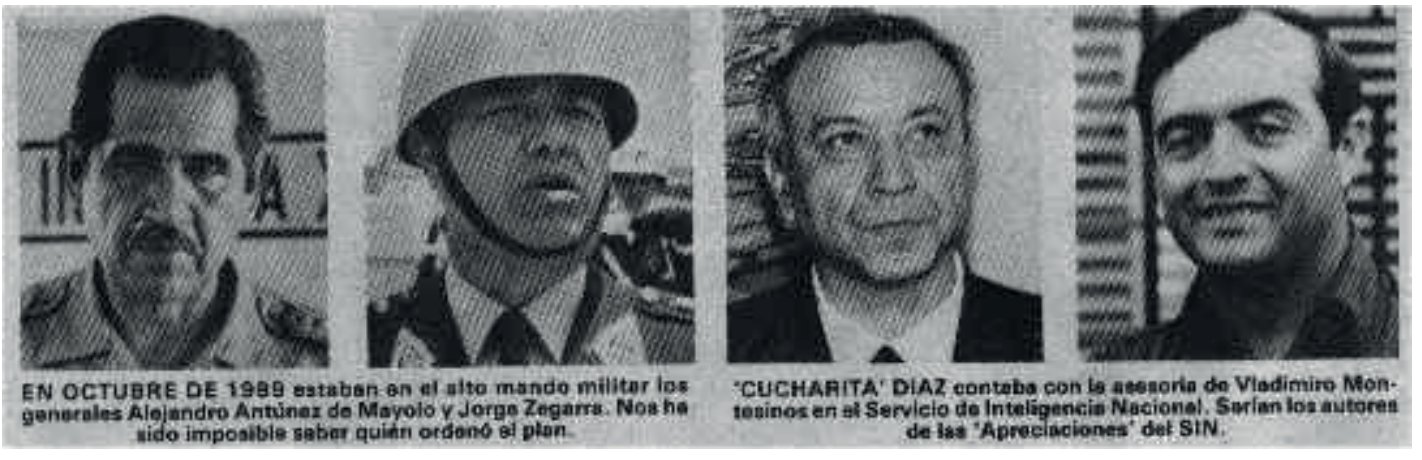

Figura 25b. Implicados. El "Plan Verde" señala como posibles autores del descabellado documento a miembros del alto mando militar cuyos rostros aparecen en esta vieja fotografía: los generales Jorge Antúnez de Mayolo (primero a la izquierda) y Jorge Zegarra (al lado). Por cierto, la redacción de la revista aclara en la misma leyenda que "Nos ha sido imposible saber quién ordenó el plan". En cuanto a los dos personajes de la derecha de la imagen, Oiga explica lo siguiente: "'CUCHARITA DÍAZ' contaba con la asesoría de Vladimiro Montesinos en el Servicio de Inteligencia Nacional. Serían los autores de las 'Apreciaciones' del SIN". Foto (detalle) obtenida del reportaje "Historia de una traición" (pp.22), de la edición de Oiga del 13 de julio de 1992. 
(Nota de Redacción: Aquí prosigue la "introducción" de Oiga a los 'anexos', titulada: "El poder en la sombra". Como habrá notado el amable lector, la redacción de este contenido se muestra más coherente y mejor elaborada que en la primera parte, apreciándose aquí el buen trabajo de un editor que ha sabido dar forma a este documento bajo los términos sintácticos apropiados. Estos análisis prosiguen, más abajo, con Los inquietantes anexos y luego una "presentación", donde se detallan los diferentes puntos con el que se pretende justificar un gobierno autoritario de corte cívico-militar, merced a un golpe de estado o a un "acuerdo" con el candidato que resulte ganador de las elecciones de 1990, en este caso, Fujimori. Luego prosigue una "Filosofía del plan político", que plantea una serie de objetivos a largo plazo -pues este pretendía ser un gobierno de largo aliento - y finalmente una "Introducción" al que sigue un cuestionario de preguntas y respuestas; algunas estas últimas de verdad que ponen los pelos de punta...)

¿Por qué ha podido Fujimori transgredir la norma sin que nada ocurra? ¿Por qué los militares nada han dicho sobre los acuerdos con Bolivia y Chile?

Basta leer el documento para explicárselo todo. Curiosamente son los militares los que han evolucionado en la cuestión fronteriza, siguiendo la orientación, que apenas se atrevían a insinuar algunos políticos, justamente por temor a la reacción castrense, hasta hace poco contraria aun a la apertura de vías de contacto con Brasil, por temor a la "invasión brasileña".

En el plan de gobierno, aceptado por Fujimori el 27 de julio de 1990, los militares plantean abiertamente la tesis -esclarecedora de todos los pasos dados por la actual política exterior peruana- de que "el concepto territorial en las cuestiones fronterizas ha sido rebasado por la ecopolítica" (sic. N. de VA). No es, pues, Fujimori el creador de una nueva y novedosa política fronteriza. No ha hecho él otra cosa que 
seguir al pie de la letra lo que dice el documento castrense del ochenta y nueve: "El poder nacional ha sufrido también poderosas alteraciones que mediatizan la capacidad ofensiva o disuasiva que el armamento de un Estado puede ejercer sobre otro... Esa concepción ha dejado paso a una nueva realidad en que el poder nacional residen en la capacidad de influir en el comportamiento de los otros estados adecuándolos o condicionándolos a los intereses en perspectiva del Estado que ejerce su influencia relativa, gracias a una organización moderna y eficiente de sus unidades productivas, aprovechando las ventajas comparativas, ubicación geográfica y desarrollo tecnológico". De allí que se plantee un acuerdo con Brasil, con miras a la intervención conjunta en la Cuenca del Pacífico. Acuerdo que, de lograrse en términos equilibrados y a pesar de los recientes desentendimientos con el presidente Franco, lograría superar los problemas geopolíticos del país.

Igual amplitud de miras, con criterio estratégico de largo plazo, se advierte en el enunciado del problema poblacional, en el educativo y en varios otros planteamientos del programa militar que, por lo que se ve ahora, es el que está siendo ejecutado por el régimen de Fujimori. Sin embargo, por desgracia, a los aspectos indudablemente positivos se unen otros que son penosa demostración de mesianismo y autocracia, negación de las sólidas virtudes del pluralismo democrático y exaltación fascista del orden, del poder y de la fuerza.

Ese lado perverso y negativo del plan, que ya preocupa, por ejemplo, en las soluciones al "excedente poblacional nocivo" (Nota 16), se hace mucho más evidentes en los Anexos que hoy publicamos, también en resúmenes y dejando constancia que no han llegado completos a OIGA: 


\subsection{Los Inquietantes Anexos}

Junto al documento -suponemos que borrador principal- que contiene los lineamientos generales del plan de gobierno de los golpistas que capturaron el poder el 28 de julio de 1990 y culminaron su pronunciamiento el 5 de abril de 1992, nos fueron entregados 'apreciaciones', que el Servicio de Inteligencia iba haciendo en aquella época, y dos cuadernillos con 'anexos' al programa, evidentemente elaborados bastante después de aquel borrador.

En ellos se puntualiza el carácter del nuevo régimen, diseñado primero para una Junta Militar de Gobierno que tendría el cuidado de recabar un amplio apoyo civil para darle al régimen una fisonomía 'civil-militar'. Posteriormente, como lo revelan los documentos que hicimos públicos la semana pasada, esta conspiración terminó por negociar la presidencia de la República o Jefatura de Estado con el presidente recién electo en junio del 90, Alberto Fujimori. Y, naturalmente, de ese arreglo surgió una nueva realidad que debió cobrar su propia dinámica, que es en la que estamos inmersos y que explicaría algunos cambios significativos en el comando militar, como las lejanas vacaciones ucranianas del general Valdivia. De todos modos, sea cual sea la dinámica de lo que está ocurriendo ahora en las profundidades de la política nacional, lo cierto es que el programa y las ideas elaboradas en los años 89 y 90 por un 'Equipo de Trabajo', desconocido por nosotros, son, en líneas generales, el programa y las ideas que sigue el gobierno de Alberto Fujimori, quien en julio de 1990 se comprometió con la Fuerza armada a poner en marcha una 'Democracia dirigida' y establecer un régimen económico de mercado libre.

He aquí algunos de los principales lineamientos contenidos en los dos cuadernillos de 'Anexos' que un pajarillo verde de alta graduación puso en las manos de nuestro director: 


\subsubsection{Presentación}

"Los requerimientos estratégicos del Estado debido a su carácter de largo plazo, requieren continuidad para la consecución de los objetivos nacionales y no la suerte que en el campo de la representación política se viene experimentando, agravado por la situación de guerra interna que los grupos subversivos han emprendido contra la Patria.

Sin una modificación sustancial en la estrategia de la conducción del Estado, así como en la solución de los problemas estratégicos, resulta inviable pensar en la extirpación de raíz de la subversión e intentar insertarnos en el concierto mundial de las naciones en el siglo XXI con opción del nivel de país desarrollado.

El presente documento se complementaria al plan Político preparado en octubre de 1989 y pretende precisar la forma administrativa del dominio estratégico del Estado con énfasis en las necesidades de la coyuntura de la guerra contra la subversión y una reconversión de la organización de las FF.AA. para que pueda hacer frente con éxito al desafío que la defensa de la Patria plantea.

En la administración estratégica del Estado se pretende, por una parte, dar continuidad y perseverancia para abordar las tareas que la situación exige y, por otra parte, mantener en la "sombra" a los recursos humanos del dominio estratégico, alejados de la línea de mira del enemigo, mimetizado dentro del cuerpo social; para resolver esta situación y concordancia con el rol a desempeñar pro el Sistema Nacional de Control, seguridad y Propaganda, se plantea como nivel máximo de la conducción nacional al Consejo Estratégico del Estado (C.E.E.) SECRETARIA EJECUTIVA NACIONAL S.E.N. y a los Directores Estratégicos. 
La reconversión de las FF.AA. y del nuevo rol que las ocupa presenta el desafío de modificar las doctrinas e hipótesis de guerra en el claro concepto de que "la guerra hay que ganarla primero dentro de nosotros mismos".

Para resolver a estos desafíos y siempre desde una perspectiva de ESTADO MAYOR es que se elabora este documento."

\subsubsection{Filosofía del Plan Político}

"La opción que presentamos es incorporarnos al modo de producción capitalista de la manera más rápida y armónica posible.

Para lo cual es imprescindible la PACIFICACIÓN del País y acabar con el Modelo MERCANTILISTA-CHICHA, para lo cual es necesario modificar el ordenamiento jurídico del país que lo impide.

Hemos definido los objetivos de largo plazo:

Preservar la integridad territorial de la Patria.

Impulsar el Poder Nacional.

Alcanzar niveles de vida de país desarrollado para la población nacional en el siglo XXI.

En la actual etapa de desarrollo de la humanidad impulsar el Poder Nacional pasa por acceder a los mercados mundiales sobre la base de las ventajas comparativas del Perú y la atracción creciente y persistente de capitales. 
Dada la aversión al riesgo en el comportamiento de los capitales es impensable una presencia creciente y sostenida sin la previa PACIFICACIÓN del país.

Dado que los daños, la destrucción y el retraso causado son inmensos, resulta imprescindible modificar de raíz y antes de que sea demasiado tarde la estrategia del Estado.

Para revertir esta tendencia y conseguir los objetivos nacionales de largo plazo es que se identificaron los PROBLEMAS ESTRATÉGICOS DEL ESTADO, su importante relativa y los cursos de acción para superarlos."

\subsubsection{Introducción}

"Hemos creído conveniente reproducir algunas de las preguntas y respuestas que fueron desarrolladas en el intercambio de criterios dentro del 'Equipo de Trabajo' que deriva en la propuesta del Consejo Estratégico del Estado:

1.- ¿Son los subversivos estructuras político-militares con diseño estratégico o diseño táctico?

R. El enfoque es estratégico y de largo plazo, las acciones tácticas se subordinan a las prioridades estratégicas.

2.- El Estado Peruano carece de enfoques estratégicos para un Proyecto Nacional y son las circunstancias y su demagogia política las que han primado con carácter inmediatista. Si el Estado Peruano carece de una estrategia económica política y 
social para sí mismo y marcha a la deriva y desincronizadamente (sic. N. de VA), cómo sería posible SOSTENER la existencia de un enfoque estratégico.

4.- ¿La organización del sistema político está en capacidad de crear las condiciones mínimas?

R.- Las últimas dos administraciones del Estado han contado con mayoría parlamentaria y no crearon esas condiciones mínimas; una próxima administración civil no tendría mayoría en el Congreso. Ni siquiera la necesidad de aplicar la pena de muerte ha sido abordada entre gente acostumbrada a los acuerdos bajo la mesa y las medias tintas, sin coger al rábano por las hojas.

5.- ¿La organización del sistema político está en capacidad de crear las condiciones mínimas?

R.- Las últimas dos administraciones del Estado han contado con mayoría parlamentaria y no crearon esas condiciones mínimas; una próxima administración civil no tendría mayoría en el Congreso. Ni siquiera la necesidad de aplicar la pena de muerte ha sido abordadas entre gente acostumbrada a los acuerdos bajo la mesa y las medias tintas, sin coger al rábano por las hojas.

6.- ¿El Sistema Nacional de Control, Seguridad y Propaganda que se plantea es el equivalente a una 'GESTAPO'?

R.- Sí, definitivamente. 
(Nota de Redacción: En la versión original del informe contenido en el presente reportaje de Oiga se omite el texto referente a las preguntas número 7 a 10, por lo que se prosigue con la \# 11)

11.- ¿Cuál es la solución que plantea el 'Equipo de Trabajo' para la conducción, organización y solución de los problemas estratégicos del Estado'?

R.- Lo que hay que hacer está delimitado en el 'Plan Político', el cómo garantizar la continuidad para cumplir los objetivos ha sido nuestra preocupación en el último periodo. La solución ha quedado delimitada en modificar la estructura de la conducción del Estado para garantizar el largo plazo y esta es la creación del Consejo Estratégico del Estado, junto con el Sistema Nacional de Seguridad y Propaganda.

12.- ¿El Consejo Estratégico del Estado sustituye al Consejo de Ministros?

R.- Son dominios diferentes, el Consejo de Ministros y el Jefe de Gobierno están determinados por la coyuntura política, son 'fusibles', pueden ser cambiados o ser víctimas de atentados. El C.E.E. es de dominio estratégico, ven los problemas de fondo y delimitan los rangos de acción del Gobierno hacia la consecución de los objetivos estratégicos. Están fuera de la línea de mira del enemigo, su existencia incluso debe de ser un secreto.

(Nota de Redacción: En la versión original del informe contenido en el presente reportaje de Oiga se omite el texto referente a la pregunta número 13, por lo que se prosigue con la \# 14)

14.- ¿Cuál es el criterio para seleccionar el C.E.E.? 
R.- El C.E.E. no ve problemas sectoriales, delimita el rumbo que debe seguir la Patria en el tiempo, discute los problemas de fondo. Solamente los niveles claves de responsabilidad del Estado en el largo plazo deben estar integrados al C.E.E. Además, la Agenda del C.E.E. está orientada hacia problemas estratégicos. Ejemplo: Las FF.AA. consumían el 5\% del PBI y el 30\% del Presupuesto del Estado para hacer frente a las hipótesis de la guerra existente en la Década del Setenta. En la Década del Noventa y ante la existencia de fuerzas subversivas, debemos revisar las hipótesis de guerra externa y readaptar estas a la realidad. Planteándonos cuáles son las nuevas hipótesis, cuáles deben ser abandonadas y cuáles reformuladas.

(Nota de Redacción: En la versión original del informe contenido en el presente reportaje de Oiga se omite el texto referente a la pregunta número 15, por lo que se prosigue con la \# 16)

16.- ¿Y la Junta de Gobierno qué rol jugaría?

R.- Primero, la Junta de Gobierno representa a las Fuerzas Armadas que, como Reserva de la Patria, han asumido la responsabilidad de la conducción de la Patria en una hora sombría. Esta responsabilidad no puede ser delegada. Lo que puede y debe delegarse son los distintos aspectos específicos que esta conducción necesita. La Junta de Gobierno puede elegir al Jefe de Gobierno para que forme un gobierno. Gobernar directamente sería desperdiciar el valioso tiempo de esta Junta en problemas de coyuntura ocasionales y rutinarios (sic. N. de VA). La Junta de Gobierno tendrá que pensar en el Perú del futuro, en seleccionar los hombres y los equipos de trabajo en perspectivas históricas.

17.- ¿Podría restársele poder a la Junta de Gobierno? 
R.- Todo lo contrario, es aliviarle de gran parte del trabajo rutinario y cotidiano, de actividades sociales y ceremoniales. En la coyuntura histórica del Perú el Poder consiste en pensar para el Perú, en elegir con sabiduría y capacidad el rumbo y los hombres para sostener el rumbo.

18.- ¿Los miembros de la Junta de Gobierno asistirán al Consejo de Ministros?

R.- Inicialmente sería poco probable el hecho de que los miembros de la Junta no asistan a un Consejo de Ministros. Sin embargo, sería un error que la Junta prestara demasiada atención a los Consejo de Ministros y perdieran de vista los problemas de fondo, donde su responsabilidad es clave y deban verse en perspectiva de futuro. Pueden siempre estar informados por video o asistir eventualmente cuando algún punto de la agenda revista un interés relevante.

(Nota de Redacción: En la versión original del informe contenido en el presente reportaje de Oiga se omite el texto referente a las preguntas número 19 y 20, por lo que se prosigue con la \# 21)

21.- ¿Qué tipo o clase de gobierno propone el esquema que tratamos de explicar?

R.- Se propone un Gobierno CIVIL-MILITAR, en el cual las FF.AA. conscientes con su responsabilidad patriótica asumen el compromiso de dirigir los destinos de la PATRIA, sin irrogarse el conocimiento absoluto de los distintos campos que necesita el manejo del Estado y que consciente de estas limitaciones por demás comprensibles y que no mellan su imagen, convocan a la civilidad honesta, responsable, patriota y técnicamente preparada.

22.- ¿El Gobierno Militar estaría dejando la conducción del Estado a los civiles? 
R.- No, quien decide por donde debe ir el vehículo (Estado) para llegar a los objetivos nacionales de largo plazo es las FF.AA. que emplea los mejores choferes (civiles) para manejar dicho vehículo."

(Nota de Redacción: En el recuadro bajo estas líneas, en apretada síntesis de la revista Oiga, van más reacciones epistolares de personajes con uniforme involucrados en este largo documento, de la pluma de Paco Igartua.)

Recuadro 02 (Cuadro del documento: Los 'Anexos' del golpe de Fujimori)

\subsection{Aclarando}

$\underline{\text { Desfile de cartas militares }}$

Inmediatamente después de la publicación del programa de gobierno que, al parecer, negoció la Fuerza Armada con Alberto Fujimori en julio de 1990, han desfilado por la revista - por medio de cartas - los diferentes jefes militares que, por una razón u otra, fueron mencionados en esa crónica. Dos de ellos, los generales Jorge Zegarra y Alejandro Antúnez de Mayolo, en términos casi idénticos, "rechazan" haber sido quienes dieron la orden para la confección de dicho programa de gobierno y alegan que, fieles a sus convicciones democráticas, nunca han conspirado contra el orden constitucional ni faltado a la lealtad a su comandante general. Y en verdad no sabemos qué responderles porque nada de lo que ellos dicen que OIGA ha dicho es cierto, y por lo tanto, no nos sentimos culpables de haber sido falsos o tendenciosos. En OIGA no se hizo otra cosa que ilustrar al público sobre cómo estaba constituido el alto mando militar en la época del trabajo político de Estado Mayor que estábamos 
publicando y, que había sido realizado por un "equipo" anónimo, que sigue siendo una incógnita hasta ahora. Dejamos que el público elaborara las hipótesis que creyera conveniente, adelantándole, eso si, que el comandante general, Artemio Palomino, era un conocido amigo del entonces presidente Alan García, lo que no significa una insinuación sobre los demás en cuanto a quien dio la orden para confeccionar el programa de gobierno del 89. Si hubiera sido alguno de ellos lo estaríamos viendo prolongado, igual que al General Hermosa, en el comando del Ejército. Mil disculpas, en todo caso, por lo que los señores generales Antúnez de Mayolo y Zegarra han creído que nosotros hemos pensado.

En cuanto al general Juan Alberto Fernández Dávila, uno de los pocos que aparecen mencionados en los documentos, queremos aclarar que su nombre apareció por un descuido en la transcripción. Nos dice el general Fernández Dávila que esa referencia a él, en torno a una intención golpista a favor de Alan García, es falsa. Afirma que, jamás estuvo en contubernios con organización política alguna y que nunca se ha apartado de su profesionalidad institucionalista. Concluye señalando a "intrigantes que, en diversas circunstancias, desearon relacionarme políticamente" y comenta que "este fue uno de los argumentos, entre otros, del que se valieron para tergiversar hechos, cuestionarme y distraer a la opinión pública, alejándome de la línea de comando del Ejército".

\section{Vergüenza de no haberle hecho caso...}

...en el Perú, la prensa está abiertamente hipotecada al poder político por medio de la tributación. Y más aún. Cuando al periodismo peruano le correspondió protestar por el trato discriminatorio que se le daba en materia tributaria -en relación a los demás países del mundo-, los periódicos peruanos optaron por negociar con el gobierno del señor Fujimori el pago de sus impuestos por medio de publicidad 
estatal. Un oscuro acuerdo, al que de inmediato se colgó la televisión, convirtiéndolo en un escandaloso negocio, en el que entró todo tipo de impuestos, o se transformó en magnánima reparación para los que tenían su tributación en regla. ¿Por qué, pues, ha de haber extrañeza cuando los medios de expresión callan lo que irrita al gobierno militar del señor Fujimori o entorpece su reelección? (Y no es que hable por despecho porque también Oiga ha firmado, aunque bajo protesta, ese bochornoso acuerdo) Editorial Nadie quiere ver ni oír y todos callan. Oiga, 2/1/95 (Nota 26)

\subsection{Paco lo había advertido}

El día 24 de marzo de 2008, Paco Igartua Rovira, fundador de los principales semanarios del país, Oiga (1948) y Caretas (1950) -este último conjuntamente con Doris Gibson, recientemente fallecida - cumplía su cuarto aniversario de fallecido. Y como en los años anteriores, la efeméride transcurrió en medio de una indiferencia casi total. Tan solo alguna que otra breve nota aparecida en un diario capitalino anuncié el triste acontecimiento... la prensa no quiere hablar nada de Paco por vergüenza, vergüenza de no haberle hecho caso cuando denunció a Fujimori y a Montesinos y pidió que todos los medios se unieran para evitar lo que finalmente sucedió, fue la expresión impotente de don Jesús Reyes Muñante, sub-director de Oiga en los 70s, cuando Paco Igartua fue enviado a uno de sus constantes exilios por su cerrada defensa de la democracia. En un coloquio de amigos, el buen don Jesús no pudo dejar de expresar, además, que Paco lo había advertido más de una vez, pues el pueblo peruano al no involucrarse como sociedad que se precia en la defensa de los derechos civiles amparados por la Constitución Política, ni en las libertades de expresión y acceso a la información, no solo no le esperaba nada bueno sino que lo peor de todo era la aparente actitud indolente, exageradamente pasiva, absurdamente indiferente, de (algunos) paisanos ante lo escandalosamente evidente. Para ese entonces, 1993, el gran temor del fundador de Oiga era la amenaza 
totalitaria que se cernía sobre el país, y puso el dedo sobre la llaga pero nadie hizo nada, y menos se ruborizaba ante las denuncias de Oiga sobre las corruptelas encubiertas y las violaciones de los derechos humanos cometidos por el gobierno de Fujimori (llámese casos La Cantuta y Barrios Altos, entre otros tantos); y, como diría Igartua, poco importó, para muchos, el acoso tributario que la Sunat (Nota 18) entidad encargada de las finanzas públicas en el Perú, tan malamente utilizada como arma política y de presión por el fujimorismo - venía ejerciendo sobre los medios de prensa que no aceptaban la forma de gobernar del "chino" después de la histórica denuncia de Oiga del 12 de julio de 1993. Por aquellos días, Eusko-Andina, la empresa editora de Oiga, se fue pues a pique en medio de la indolencia de los otros medios apoyados por el oficialismo con los "favores" que venían recibiendo aquellas televisoras, radios y publicaciones impresas afines al régimen. Se advirtió pero nadie escuchó, se denunció pero nadie hizo nada, se alzó la voz de protesta, pero era como en la bíblica frase, la voz que grita en el desierto, ó dicho de otra forma, era como si Dios se hubiera muerto..., valga la alusión. Y lo peor de lo peor fue que había personas que, si no le echaban la culpa a la gente de esta falta de reacción ante las injusticias, los abusos de poder y las deshonestidades de ciertos personajes encumbrados por la circunstancia, políticos y funcionarios públicos que, pacata mía, obraban al amparo de la impunidad más descarada, era el hecho de que había quienes parecían hacer todo lo posible para que otros prójimos no se enteraran de acontecimientos que deberían ser de dominio público. Francisco Igartua, visionario como solo él era, en su editorial Nadie quiere ver ni oír y todos callan (Oiga, 2/1/95) (Nota 19), aludiendo a un caso de corrupción en el seno de las más altas esferas del fujimorismo -cuando este aspiraba a una reelección, que ya estaba "programada" en 1995 - , escribió... Cada día se hace más evidente la voluntad de fraude del gobierno militar que preside Alberto Fujimori, pero lo curioso del caso es que los medios de expresión cada día ocultan más este hecho a la opinión pública. Por ejemplo, la semana pasada se han producido dos situaciones de tanta resonancia que cualquier 
sociedad se hubiera conmocionado con ellas. Pero aquí no pasó nada. Ni siquiera hubo el comentario chismoso y socarrón de Lima... ¿Será, me pregunto, que el desánimo ante tanta adversidad -no solo la de ahora sino la de siempre- ha terminado por castrar a los peruanos, añadiendo a la antigua indolencia una buena dosis de moderna despreocupación por la actividad cívica...? Pero no. La realidad es otra. Lo que ocurre es que el público no se entera debidamente de los hechos ni los medios de difusión cumplen su misión de orientar a la sociedad informando a conciencia de los hechos sucedidos... Más abajo, el maestro Igartua añade... Por otro lado, el general de división en retiro, Luís Cisneros Vizquerra, Más conocido como 'El Gaucho', en un programa de televisión (en canal 13) acusó al alto mando del Ejército de estar destruyendo a esa institución por -entre otras cosas - involucrarla en la persecución del narcotráfico, que es labor policial y balde de miel para tentar a la corrupción. También esclareció por qué es aberrante el ascenso del general Pérez Documet, responsable de que nadie, sin orden expresa suya, entrara ni saliera de La Cantuta el día del asesinato de los nueve estudiantes y un profesor de esa universidad... y ni ese canal ni ningún otro medio de difusión masiva se hizo eco de tamaña denuncia... ¿Por qué, pues, acusar al pueblo de desidia, de apatía, frente a la cosa pública, si el público solo se informa de lo que no molesta en demasía al señor Fujimori y al alto mando militar Líneas más abajo, el autor hace hincapié en el caso del acoso tributario contra Oiga y otros medios, cuando escribe: ...en el Perú, la prensa está abiertamente hipotecada al poder político por medio de la tributación. Y más aún. Cuando al periodismo peruano le correspondió protestar por el trato discriminatorio que se le daba en materia tributaria -en relación a los demás países del mundo-, los periódicos peruanos optaron por negociar con el gobierno del señor Fujimori el pago de sus impuestos por medio de publicidad estatal. Un oscuro acuerdo, al que de inmediato se colgó la televisión, convirtiéndolo en un escandaloso negocio, en el que entró todo tipo de impuestos, o se transformó en magnánima reparación para los que tenían su tributación en regla. ¿Por qué, pues, ha de haber 
extrañeza cuando los medios de expresión callan lo que irrita al gobierno militar del señor Fujimori o entorpece su reelección? (Y no es que hable por despecho porque también Oiga ha firmado, aunque bajo protesta, ese bochornoso acuerdo).

\subsubsection{Otra vez la inútil conseja de Brecht}

En otro acápite, el maestro Igartua remarca sus afirmaciones, en clara alusión a la actitud de la sociedad civil y los medios de comunicación y la reacción de algunas autoridades, cuando Fujimori pretendió desprestigiar la institucionalidad del país. Y analiza la evasiva reacción del periodismo peruano, matizada por la indiferencia de la opinión pública, ante el ataque del fujimorismo contra varias instituciones tutelares de la nación, como el denuesto contra la Iglesia Católica cuando en ese entonces era arzobispo de Lima el cardenal Augusto Vargas Alzamora. En su editorial titulado Otra vez la inútil conseja de Brecht (Oiga, 11/8/95) (Nota 20), Paco Igartua no puede dejar de expresar su indignación cuando escribe que... Se ha repetido tantas veces la conseja de Brecht, y tan inútilmente, que me parece perder el tiempo volverla a citar: Vinieron por el sastre de abajo, pero yo no era sastre... vinieron por el vecino religioso, pero yo no era religioso... Hasta que vinieron por mí... Lo mismo está ocurriendo hoy en el Perú y nadie o casi nadie se inmuta. La persecución no es contra ti, contra los individuos, sino contra las instituciones, muchas veces contra corporaciones adversas a tu sentir y ajenas a tu gremio, por lo que te quedas quieto, sin advertir que la próxima puede ser tu comunidad. Se agravió, por ejemplo, a los jueces y magistrados y se arrasó con la institución judicial... y muchos pensaron ¿por qué deberían preocuparse los que no eran jueces o magistrados?... Lo mismo ocurrió con los Colegios Profesionales, pero como millones de peruanos no son profesionales ¿por qué habría que cundir la alarma?... Los municipios fueron atropellados, pero como la mayoría no es concejal ni pretende serlo hubo silencio... Se vilipendió a los políticos y a los partidos y como políticos ni 
partidos son gratos cuando están lejos del poder, la multitud los repudió y los halló "tradicionales", la nueva voz descalificadora... Ahora le ha tocado el turno a la Iglesia, y para agravarla impunemente, con alevosía y ventaja, el agravio vino unido a un tema sobre el que la Iglesia sostiene una posición que no es bien vista por la mayoría de las gentes. Y la reacción es: ¿por qué rechazar esos agravios si uno no es religioso? ¿Por qué preocuparse por el manoseo a una institución que sostiene una posición diametralmente contraria a la libertad sexual, a la que uno es afecto? Se trataba aquí de un conflicto creado por el entonces reelecto Presidente de la República (1995) -fraude electoral dixit-, quien se refirió de forma insultante al papel de la Iglesia en los temas del control de la natalidad y le libertad sexual en su discurso del 28 de julio de aquel año, en un gesto a todas luces más político que de otra índole pues, en el fondo, se trataba de una vulgar provocación y quiso atizar el fuego sobre algo que no tenía nada que ver con condones ni con "te" de cobre ni con abstinencias ni con píldoras y ni siquiera con el aborto. Se trataba de un gesto político, repetimos, dirigido a someter a la Iglesia como institución. La intención política no puede estar más clara -prosigue Igartua - y solo a los ingenuos se les ocurre caer en el juego y enzarzarse en la oscura polémica sobre métodos para lograr el sexo seguro. La Iglesia, con habilidad antigua, no cayó en el anzuelo. Planteó en un comunicado del pleno episcopal, su razonado rechazo al aborto, al asesinato de una vida ya nacida, expuso su doctrina sobre los métodos de planificación familiar y con un largo capotazo alejó de sus terrenos al toro bravo que el gobierno le había soltado. Y para rematar la faena, con sosiego de civilización añeja, monseñor Irizar explicó: "cada pareja y persona es responsable por su vida conyugal; en ese sentido nosotros ayudamos -desde la Iglesia - a formar conciencia, pues, al final, cada persona decide su conciencia ante Dios. Por eso, al santuario de la conciencia, no entramos; allí no entra nadie, mucho menos el Estado." En resumen, la Iglesia no propone ni alienta una política poblacional. Ese es terreno del Estado. Lo que la Iglesia tiene es una doctrina al respecto que los fieles a ella y los hombres de buena voluntad están en 
libertad de seguir. Una doctrina que no propugna la procreación irresponsable sino la paternidad responsable y a la que le preocupa no tanto el número de habitantes sino la forma como estos aumentan. $\mathrm{Y}$ la sociedad peruana tuvo que enterarse de los detalles de esta absurda trifulca institucional -Ejecutivo vs Iglesia Católica - gracias a un reportaje publicado en la revista Oiga, el único medio impreso que le dio una cobertura decente, a la altura de la trascendencia de los hechos, mientras la mayoría de emisoras radiales y televisivas, amén de otros periódicos y revistas -sobre todo los representantes de la prensa "chicha" o sensacionalista adicta al régimen - o se cohibía o pasaban por alto un incidente donde el gran perdedor fue, finalmente, el propio inquilino de turno de la Casa de Gobierno.

Algo parecido se podría decir de lo que sucedía en los años 80, durante el primer y desastroso gobierno de Alan García, y a comienzos de los 90, ya en pleno fujimorismo: cada vez que se publicaba alguna escueta y lejana noticia sobre las incursiones de Sendero Luminoso y las no menos letales de los efectivos del Ejército y la Policía Nacional del Perú en las alturas de Ayacucho o Huancavelica, el público limeño no hacía sino encogerse de hombros, como diciendo con desdén: ¿y a mí qué? Las noticias eran tan remotas, aún estando en nuestro propio país, que nadie se conmovía por las desgracias ajenas de los hombres, mujeres, niños y ancianos asesinados por la irracionalidad. Acá había gente que se indignaba más por los lagrimones de las telenovelas que por la muerte de una inocente víctima de la violencia subversiva o contrasubversiva. Cuando los ataques de los grupos terroristas y la guerra sucia del Estado se trasladaron a las zonas urbano marginales de las grandes ciudades costeras, sobre todo de Lima, cuando esta "guerra" comenzó a cobrar sus primeras víctimas en los asentamientos humanos, en las barriadas pobres, la población urbana continuó viendo el asunto como si esto estuviera ocurriendo en la China o en la Cochinchina; pero no, la atroz realidad era, y eso no lo querían entender, que eso estaba sucediendo delante de sus propias narices, en el 
Perú. Y tuvo que llegar aquella noche del aciago 16 de julio de 1992, con el atentado terrorista en la calle Tarata (Nota 21), en pleno centro del distrito limeño de Miraflores, cuando un grupo senderista lanzó una camioneta repleta de "anfo" -una combinación de pólvora con nitroglicerina - y dinamita contra la fachada lateral de un edificio. La explosión despedazó todo un barrio y mató a una veintena de personas. Esto tuvo que suceder para que recién allí quienes se creían intocables, que "nada les podía pasar", se dieran cuenta, con horror, que a ellos también les tocaba. En aquel hecho criminal no solo hubo muchas muertes, sino que se demostró cuán importante era que los medios cumplieran a cabalidad con su rol informativo con total objetividad y transparencia, sin venderse a ningún interés político o económico, y que los ciudadanos se preocuparan por informarse como debe ser. Pero, por desgracia, este baldazo de agua fría en los egos de tantos indiferentes ciudadanos y medios de comunicación faltos de madurez cívica, solo sirvió para que se tome conciencia de ello por poco tiempo. Luego, otra vez se retornó a la pertinaz abulia del hombre de la calle y el desinterés mediático, que terminarían haciendo oídos sordos a las advertencias y denuncias de Oiga cuando se supo quienes estaban detrás de los asesinatos selectivos perpetrados en el país y que estos parecían formar parte de los lineamientos de un siniestro "plan de gobierno secreto" que un "pajarillo verde" puso en las manos de don Paco en julio de 1993. Todo continuó igual o peor. Incluso había publicaciones impresas a las que, curiosamente, no parecía salpicarles el barro, pues decían poco o nada de los problemas internos del país, o solo tocaban noticias morbosas y de sangre que nada tenían que ver con la subversión o con las violaciones de los derechos humanos perpetrados por algunos miembros de las Fuerzas Armadas y policiales. Y mientras estos medios estaban en sus trece, otros, apenas unos contados, como la revista Oiga, informaban abiertamente. Estos últimos comenzaron a tener problemas con el Gobierno o con la Sunat y otras entidades estatales reguladoras tan pronto pusieron el dedo sobre la llaga. En medio de todo este batiburrillo, Oiga fue quizás el único medio impreso que supo comprender en su 
totalidad la tragedia que se estaba viviendo, agravada por el accionar de una dictadura que casi nadie quería cuestionar, reconocer o aceptar que existía.

Este era, pues, el corolario de los acontecimientos que se vivieron en aquel turbulento Perú de 1993 y en los años siguientes, hasta llegar a ese aciago 5 de septiembre de 1995 (Nota 22). Todos estos hechos fueron previstos con antelación gracias al carácter visionario, hasta intuitivo, del fundador de Oiga, pero casi nadie lo tomó en serio. Cuando don Paco supo que Fujimori iba a ser presidente, en 1989-90, advirtió de sus antecedentes delictivos de corrupción y actos deshonestos al interior de la universidad en donde fue catedrático; también alzó la voz ante el ilegal "autogolpe" del 5 de abril de 1992, y quiso alertar a "sus colegas" de otros periódicos y revistas del peligro que significaba un gobierno "cívico-militar" de corte totalitario y perverso; Paco Igartua denunció que aquel régimen no solo iba a ser una dictadura sino de lo que vendría después: un feroz control de la libertad de expresión y la implantación de un sistema económico neoliberal perverso que benefició a unos pocos y dejó a millones de trabajadores en la calle, además de reducir los sueldos de maestros y policías a niveles infrahumanos -fue la época en la que si alguien reclamaba por cuestiones laborales, era acusado de 'terrorista' sin ningún fundamento - y rebajar las pensiones de viudas y jubilados a cifras miserables, y todo ello a pesar de la tan pretendida "bonanza económica" que muchos no vieron. Paco Igartua advirtió asimismo del acoso tributario al que comenzaron a ser objeto los diarios y revistas, como Oiga, amén de otros medios, cuando estos no inclinaban sus líneas editoriales a los intereses gubernamentales. Pero fue como hablar con las paredes: nadie hizo caso. Igual suerte corrieron sus denuncias contra los abusos de poder de los funcionarios públicos fujimoristas, contra los magistrados afines a la dictadura -empezando con la entonces fiscal de la Nación, Blanca Nélida Colán, nombrada a dedo por la dedocracia fujimorista - y contra los crímenes de lesa humanidad. Menos le hicieron caso cuando advirtió de la existencia del perverso Plan Verde que Fujimori, con la 
anuencia de algunos círculos militares, había comenzado a poner en práctica contra la ciudadanía y sus instituciones. Pensar que se criticó mucho que Fujimori llegara al poder "sin plan de gobierno". Obstinado él, nunca quiso hablar del asunto durante su etapa pre-electoral (1990), sólo se limitó a embaucar a las multitudes diciéndoles engañosamente lo que éstas querían escuchar, bajo el lema "honradez, tecnología y trabajo" - , y la razón era que tal plan existía pero había sido ocultado a la opinión pública a causa de su incendiario contenido, amén de otros propósitos oscuros, hasta que Oiga reveló su existencia. Finalmente, la falta de interés de la ciudadanía y de la prensa ante estos hechos, que ponían en tela de juicio la credibilidad del régimen, terminaría por pasar factura. El gran pecado del Perú ha sido la indiferencia, fue una de las conclusiones del Informe Final de la Comisión de la Verdad y la Reconciliación (CVR) que investigó todos los casos de violaciones de los derechos humanos entre 1980 y 2000, vinieran de donde vinieran. Y no estaban tan perdidos los de la CVR (Comisión de la Verdad y la Reconciliación). Si examinamos el cariz de los acontecimientos nacionales y el rumbo que tomó la vida y lucha de Francisco Igartua ante semejante estado de cosas, no nos será difícil inferir lo siguiente: así como vinieron de buena fuente las denuncias y advertencias sobre lo que estaba sucediendo en el entorno de las más altas esferas del régimen fujimorista, y lo que éstos tramaban para convertirse en los dueños absolutos del país, creando una dictadura despiadada a costa de los más débiles, de la misma forma fueron ignoradas; ahora, acordarse de eso es como decir: acuérdate peruano... de la insensatez de no haber querido escuchar, reconocer, aceptar, en su debido momento, que una vez elegiste al peor candidato, a pesar de que se te dijo, que la subida al poder de cierto individuo de ojos rasgados con apellido japonés, y con este, la de sus compinches -con Vladimiro Montesinos a la cabeza-, no le iban a hacer ningún favor al Perú. Paco Igartua sabía todo esto y, repetimos, a él no le hicieron caso, y pagó caro por haber dicho la verdad... con el cierre de su revista; y después, quienes cancelaron la factura, por su indiferencia, por su indolencia, por su estupidez, fueron 
los propios peruanos, que perdieron en medio del río revuelto en donde solo pescaron algunos vivos y sinvergüenzas.

\section{6. ¿Sabía usted qué...}

...la denuncia de la desaparecida revista Sí del 12 de julio de 1993 se dio justo el mismo día en que Oiga denunciaba, por su parte, la existencia del "Plan Verde"?

...varias de las víctimas masacradas el 3 de noviembre de 1991 por el Grupo Colina en la matanza de Barrios Altos, curiosamente, habían votado en segunda vuelta a favor de la candidatura presidencial de Alberto Fujimori, el autor y ejecutor intelectual de su asesinato?

...tan preocupado estaba don Paco Igartua por el futuro del país bajo el gobierno de Fujimori, que en varias ocasiones expresó... ¡Pobre Perú!, frase que incluso fue título de uno de sus editoriales?

... los medios informativos adictas a la dictadura controlaban, minimizaban y hasta ocultaban las informaciones desfavorables al gobierno, en tanto que sobredimensionaban todo aquello que de alguna manera le resultaba conveniente a su imagen. Esa fue la cortina de ignorancia y mentira que Fujimori manipuló a su antojo durante su régimen?

...El control ejercido sobre la prensa (obtenido mediante presión tributaria y amenazas judiciales) permite la censura de noticias incómodas al régimen, la tergiversación de la información y hasta la abierta mentira a favor del gobierno. Esto fue muy evidente durante la última campaña electoral, cuando los canales de televisión de señal abierta transmitían en forma abrumadora la propaganda 
oficialista y los mítines políticos del candidato Fujimori, mientras se negaban a transmitir la propaganda de los candidatos opositores (aun siendo pagada) y sus manifestaciones públicas? (Nota 29)

...tras el cierre de Oiga, la revista Caretas hizo lo que antes no había hecho: reconocer que Oiga era una publicación con la que no siempre se estuvo de acuerdo pero que era necesaria dentro del abanico de opciones periodísticas del país?

...Chino, ¿contigo hasta la muerte? Con este editorial, don Paco Igartua inició la "guerra" contra la dictadura... tras el autogolpe de Fujimori del 5 de abril de 1992 con el que se dio comienzo a la demolición del estado de derecho y sus instituciones tutelares. Paco dijo, en ese entonces, que... Es casi ocioso iniciar este editorial condenando el golpe militar del 5 de abril y repetir lo que e1 el Perú ilustrado comenta: que el ingeniero Alberto Fujimori, al violar la Constitución y autoproclamarse dictador, amo absoluto del país, ha perdido la legitimidad que le dieron los votos y su juramento de lealtad a la Constitución. Fujimori ha dejado vacante la presidencia constitucional?

...Caretas también mencionó al "Plan Verde", así dijo: "En ese amplio editorial, dibujaba CARETAS la creciente fuerza del autoritarismo personal de Fujimori. Ese rasgo personal se entrelazaba ahora con un proyecto antidemocrático castrense. El sonado Plan Verde, urdido por los militares contra Alan García a fines del gobierno de éste, encontraba la ocasión de plasmar su fórmula fascistoide, con un presidente civil. No propugnaba un régimen militar, pero sí uno basado en los tanques y las demás armas de la fuerza pública. Vladimiro Montesinos era el enlace entre Fujimori y la cúpula castrense. "Del artículo "5 de abril de 1992: El autogolpe de Alí Baba" (Nota 31) 
...lo denunció Oiga y también Caretas, cosa que luego fue confirmada: el Grupo Colina se formó secretamente durante los dos primeros años del gobierno de Fujimori, y tenía licencia para realizar ejecuciones extrajudiciales y desapariciones forzadas; se trataba de un escuadrón de aniquilamiento que, incluso, como ya se vio, recibía felicitaciones presidenciales por su "trabajo"; casualidad o no, tal accionar criminal fue uno de los puntos planteados en el texto del "Plan Verde"?

...70,000 muertos fue el saldo aproximado de vctimas provocadas por la violencia política en el Perú bajo los gobiernos de Fernando Belaunde, Alan García y Alberto Fujimori, según la CVR (1980 a 2000)?

\section{Para saber más}

(Nota: A la derecha de los hipervínculos se ha insertado la fecha de última apertura de la página Web citada)

Diario El Mundo (Madrid) Estériles por decreto.

http:// www.elmundo.es/magazine/num181/textos/este1.html (3/9/08)

Fujimori y Montesinos:

http:// stucchi.tripod.com/politica/fujimon.htm (30/8/08)

Fujimori, la justicia peruana te reclama.

http://www.aprodeh.org.pe/fujimori/index.htm (30/8/08)

La Cantuta. Contenido basado en un artículo de la revista Oiga.

http:// stucchi.tripod.com/politica/cantuta.h (30/08/08) 
Los medios peruanos en busca de la credibilidad.

http://www.revistaprobidad.info/016/026.html (27/8/08)

Los grandes corruptores. http://www.pulso.org/Espanol/Archivo/Miami.htm $(30 / 8 / 08)$

La cultura de la gallina. http:/ / stucchi.tripod.com/politica/gallina.htm (27/8/08)

Puente Aéreo - Lima la indiferente.

http:/ / puenteareo1.blogspot.com/2006/02/lima-la-indiferente.html (27/8/08)

Resistencia - El Plan Verde o la historia de una traición.

http://www.resistencia.org/documentos/el_plan_verde/el_plan_verde_p1.htm $(30 / 8 / 08)$

Informe de la Comisión de la Verdad y la Reconciliación CVR - Las Fuerzas Armadas.

http://www.cverdad.org.pe/ifinal/pdf/TOMO\%20II/

CAPITULO\%201\%20-\%20Los\%20actores\%20armados\%20del\%20conflicto/

1.3.\%20LAS\%20FUERZAS\%20ARMADAS.pdf (30/08/08)

Wikipedia, la enciclopedia libre: Cambio 90

http://es.wikipedia.org/wiki/Cambio_90 (30/8/08)

Entrevista a Francisco Igartua Rovira.

http://www.euskonews.com/0187zbk/elkar18701es.html (30/8/08)

Rebeliones y Golpes de Estado en el Perú. 
http://www.adonde.com/historia/rebeliones.htm (30/8/08)

Pequeña biografía de Francisco Igartua Rovira.

http://www.euskosare.org/euskal_mundua/pertsonak/igartua_rovira_francisco $(30 / 08 / 08)$

Siglo XX peruano: la huella de la barbarie - Comentario al libro "Muerte en el Pentagonito" del periodista Ricardo Uceda.

http://www.andes.missouri.edu/andes/Comentario/MC_Pentagonito.html $(1 / 9 / 08)$

Presunción Fundada - Pruebas que comprometen a Fujimori (las pruebas para la $\begin{array}{lllll}\text { extradición } & \text { fe } & \text { Fujimori } & \text { Chile) }\end{array}$ http://www.hrw.org/spanish/informes/2005/peru1205/index.htm (1/9/08)

II. Antecedentes: el Gobierno de Fujimori (las pruebas para la extradición de Fujimori en Chile)

http://www.hrw.org/spanish/informes/2005/peru1205/2.htm (1/9/08)

Palestra de la Comunicación PUCP - ¿Cómo se construyen las Agendas Públicas? El Fujimorismo como antimodelo. http://palestra.pucp.edu.pe/pal_com/?file=comupoli/verastegui.htm $(1 / 9 / 08)$

Fujimori: el exiliado ante la justicia - Hermoza Ríos admite haber formado triunvirato de poder con Fujimori y Montesinos. http://www.terra.com.pe/noticias/articulo/html/act1325490.htm (1/9/08) 
I. Casos presentados por el gobierno peruano a la Corte Suprema Chilena para la extradición de Alberto Fujimori.

http:/ / fujimoriontrial.org/?page_id=90 (1/9/08)

Vladimiro Montesinos SI se pueden cometer delitos por razones de Estado.

http:/ / fujimoriontrial.org/?p=378 (1/9/08)

Según la información de la PNP las víctimas de La Cantuta y de Barrios Altos no eran parte de Sendero Luminoso.

http:/ / fujimoriontrial.org/?p=431\#comment-3418 (1/9/08)

Más sobre Fujimori.

http:/ / fujimoriontrial.org/?page_id=42 (1/9/08)

Comisión de la Verdad y la Reconciliación CVR.

http://www.cverdad.org.pe/ (1/9/08)

Comisión de la Verdad y la Reconciliación CVR Informe Final.

http://www.cverdad.org.pe/ifinal/index.php (1/9/08)

You Tube La matanza de Barrios Altos.

http://www.youtube.com/watch?v=ED_lmW3zNVU (1/9/08)

Revista Caretas. Caso Barrios Altos revive.

http:// www.caretas.com.pe/2000/1640/articulos/barrios-altos.phtml (1/9/08)

Volver al principio del capítulo Volver al principio del artículo Volver al principio 


\section{Epílogo: Los últimos días de Oiga}

Como no podía ser de otra forma, las valientes denuncias de Oiga de aquel 12 de julio de 1993, y su continuidad en una edición siguiente, materias este trabajo periodístico, fueron la excusa perfecta para que sobre Eusko-Andina, la empresa editora de la revista, cayeran todos los diablos azules y demás de la dictadura fujimorista. Oiga. La revista, que se había convertido en uno de los últimos enclaves de la decencia periodística en el Perú, fue víctima de un acoso despiadado en el que se utilizó como arma, primero la parte financiera y tributaria, y luego la parte publicitaria.

La historia de la última etapa de Oiga estuvo marcada por acontecimientos que pintan de cuerpo entero a su principal protagonista y a un marco socio-político al que tuvo que enfrentar el fundador de la revista Oiga. Luego del golpe de Estado del 3 de octubre 1968, Paco Igartua mostró un ligero apoyo a la llamada "Revolución Peruana" del general Juan Velasco Alvarado, razón por la cual fue tildado de "velasquista". Se trató de una postura de la que tuvo que retractarse al notar el verdadero cariz del gobierno militar de turno, cuando éste confiscó los medios de comunicación limeños en junio de 1974 --particularmente algunas revistas, periódicos, emisoras radiales y canales de televisión -; entonces, el fundador de Oiga se opuso en una cerrada defensa del estado de derecho y de la libertad de expresión, marcando distancias con la "junta militar" en una actitud valiente que finalmente determinó su destierro a México, país de donde, sin embargo, continuó enviando sus editoriales para una Oiga que nunca cejó contra la dictadura. En 1978, cuando el gobierno de Francisco Morales Bermúdez permitió el retorno al Perú de los periodistas deportados por Velasco, Paco Igartua regresó a Lima para toparse con una incipiente democracia, bajo el tibio renacer del segundo mandato de Fernando Belaunde Terry -de 1980 a 1985-, que se fue al traste por la hiperinflación galopante 
del primer mandato de Alan García - de 1985 a 1990 - . La gran mentira de la frase "honradez, tecnología y trabajo" que Fujimori acuñó y utilizó, cual lema de campaña electoral, cuando todavía era un don nadie en la política nacional, le sirvió para engañar al pueblo peruano y así ganar las elecciones de 1990. Una vez en el poder, lo primero que hizo el "chino" fue aplicar uno de los puntos fundamentales de su plan de gobierno, que nadie conocía: la reforma del sistema económico que empezó en agosto de aquel año con el brutal "shock" anunciado en mala hora por el entonces ministro de economía Juan Carlos Hurtado Miller, que provocó una desmesurada alza en los precios para nivelar los altísimos costos de los productos de primera necesidad a un nuevo patrón monetario, el nuevo Sol, que reemplazaba al devaluado Inti de Alan García. La nueva política económica -de corte neoliberal - fue después continuada por el sucesor de Hurtado Miller, Carlos Boloña Behr, quien introdujo un nuevo ordenamiento legal y laboral en la vida económica del país. Esto trajo devastadoras consecuencias para la población peruana. El capitalismo a ultranza en el Perú, en vez de ser una oportunidad para la gente, dejó como víctimas a millones de trabajadores pateando latas y otros millones de compatriotas emigrando del país, huyendo del hambre y la miseria.

Durante los primeros años del fujimorismo, la inseguridad interna, la inestabilidad política, el narcotráfico, la violencia subversiva y la violencia "de Estado" -estas dos últimas parecían competir entre sí, como queriendo saber cuál era la más cruel y sanguinaria - matizaron la desesperanza de la sociedad civil. Paco Igartua tuvo que despertar aquí a una nueva pesadilla, como la de las otras dictaduras. Durante sus dos primeros años, el gobierno de Alberto Fujimori, con la "colaboración" del siniestro "asesor" Vladimiro Montesinos (1990-1992) -el ya mencionado "poder en la sombra" - , además de las reformas legales y macroeconómicas que se hicieron con la intención de "reinventar" el país en beneficio de los intereses de un régimen político que iba a devenir en autoritario, corrupto y despótico, se puso en funcionamiento un 
sistema de copamiento estatal en las empresas periodísticas nacionales con el fin de controlarlas sutilmente y mantenerlos como soporte mediático para los planes que se habían trazado quienes pretendían perpetuarse en el poder.

\subsection{El acoso de la Sunat}

Fue bajo este contexto cuando, en una bien montada estrategia para hacer realidad sus objetivos, aquel Gobierno instituyó la figura del "acoso tributario" -que muy pocos peruanos conocían en su real dimensión- como un arma de represión financiera para presionar despiadadamente a cuanto ciudadano no estuviera de acuerdo con los lineamientos del régimen. Así fue como la parte financiera y tributaria del engranaje económico del país acabaron convirtiéndose en los principales instrumentos de ejecución de la mafia enquistada en la Casa de Gobierno y en las principales instituciones tutelares de la Nación, además de las entidades estatales más estratégicas, entre estas el Congreso de la República -que tenía mayoría fujimorista -, los ministerios del Interior y de Defensa -manejados por personajes adictos al régimen-; a estos se sumaban la Fiscalía de la Nación -su principal autoridad era elegida a dedo-, el Poder Judicial -que había perdido toda autonomía - y, cómo no, el Ministerio de Economía y la Sunat -que aplicaron las nuevas y nefastas reglas económicas de un juego al que tenían que estar sujetos los ciudadanos comunes. Pero fue la Sunat quien obtuvo las mejores facilidades de acción coactiva para llevar a cabo una represión soterrada en total impunidad. Esta nueva modalidad -la persecución financiera y tributaria-, como era de esperar, terminó afectando tanto a medios de comunicación críticos del Gobierno como a toda empresa privada o persona natural y/o jurídica que no comulgara con el fujimorismo. La Sunat de aquella época recibió, pues, todas las prerrogativas del caso para que haga los mejores esfuerzos en doblegar en especial a los medios considerados "independientes". De esta forma, buscaron apropiarse de las líneas 
editoriales de diversas emisoras radiales, canales de televisión, periódicos y revistas, y hostigar a aquellos medios independientes - desafortunadamente pocos - que, como la revista Oiga, supieron mantener muy en alto la dignidad periodística.

Contra Oiga, los ataques recrudecieron cuando la dictadura comprendió que se enfrentaba a una fortaleza de valores éticos y morales bajo la figura insigne de su fundador y director. Cuando los esbirros del Gobierno de Alberto Fujimori no supieron cómo doblegar la línea editorial de la revista, como ya había sucedido con otros medios impresos que se habían vendido al mejor postor -entre estos los diarios capitalinos OJO, Correo, Expreso, además de los llamados "diarios chicha" o sensacionalistas, como Ajá, El Tío, La Tía, El Chino, Extra, El Mañanero, El Men, La Chuchi, etc. - . Los inspectores del bautizado "escuadrón de la muerte", misma Gestapo en versión peruana, comenzaron a realizar insistentes visitas a la empresa Editora Eusko-Andina S.A, en su local del Paseo Parodi en San Isidro, que se encargaba de la impresión y venta de la revista Oiga. Sin un motivo aparente que lo justifique, estos señores se aparecían cada 30 días, y cuando se retiraban por fin eran reemplazados inmediatamente por otro "escuadrón" que, orden en mano, no entendía razones. El objetivo de tales acciones era muy claro: cerrar la empresa y, posteriormente, apoderarse de la revista y la marca para sus nefastos fines. Fue pues, en estos instantes, cuando Montesinos dejó grabadas estas reveladoras palabras: Igartua es un hombre muy difícil. Frase que expresaba la frustración del Gobierno por intentar adueñarse de la línea editorial de una publicación que se había convertido en un hueso muy, pero muy duro de roer, y así iba a permanecer, fiel a su bandera hasta el fin.

Desde luego que tales escuadrones "no mataban", vale decir, no era una "muerte física" como se diría; era, en definitiva, algo peor, como la llamada "muerte civil" que antes se aplicaba en el Perú sobre quienes no cumplían con el deber de votar en las 
elecciones municipales ó presidenciales. Sencillamente se trataba de destruir, empezando por la honra y la credibilidad, a los civiles comunes y corrientes, a las instituciones --no se libraron ni siquiera las entidades públicas, como el Poder Judicial, que fue vilipendiado, o las instituciones tutelares, como fue el caso de la Iglesia Católica, a quien pretendieron desprestigiar ante la opinión pública, como se verá más abajo-; se acosaba de forma inmisericorde a las empresas o a los empresarios apelando a su punto más débil: su parte financiera. En el caso de la sociedad civil, se trataba de un sistemático "ninguneo" existencial en el que, mediante los métodos más ruines y sórdidos, se pretendía anular o aniquilar "legalmente" a cuanta persona natural que no se prestara a los propósitos de la dictadura.

Después, el acoso sistemático se trasladó a todas los agentes publicitarios, en el caso de Oiga, que fueron perseguidos por publicar sus anuncios en la revista que le seguía los pasos al Gobierno del "peruano de ojitos rasgados". Si el anunciante persistía en su empeño de publicar anuncios en las páginas de una publicación contraria al régimen, las visitas del "escuadrón de la muerte" de la Sunat se trasladaban inmediatamente a sus clientes, es decir, no perdían el tiempo. Esto fue lo que sucedió precisamente con Eusko-Andina, que terminó recibiendo un trato más duro que el que recibían otras empresas periodísticas con deudas muchos más altas pero que habían vendido sus líneas editoriales a los intereses del régimen, como fueron los casos de Epensa, editora de los diarios OJO, Ajá, El Bocón y Correo, Diario Expreso SA y Panamericana Televisión, canal 5, entre otros. Para justificar este accionar, la mafia fujimontesinista se aprovechaba del acuerdo del Estado con todos los medios de comunicación, mediante el cual las deudas de éstos con la Sunat y el IPSS -hoy Essalud- eran canjeadas por publicidad estatal o de empresas adictas al Gobierno; una vez emitido el cheque por el Estado a favor de la empresa, entidad o persona deudora, esta lo endosaba a favor de la institución acreedora. Así era como funcionaba el "sistema", lo cual permitió sobrevivir a empresas de comunicación 
social que tenían deudas astronómicas con el fisco y la Seguridad Social (IPSS). Y esto fue lo más extraño, pues, como ya indicamos arriba, mientras para Eusko-Andina todo fueron discriminaciones, recortes, restricciones, fiscalizaciones y exigencias, para las otras empresas adictas al Estado, las "preferencias" financieras y publicitarias, que sino tributarias, por parte del Gobierno, eran manifiestas.

Paradójicamente, el acoso se trasladó también a las agencias de publicidad afines al gobierno -hoy la mayoría de sus propietarios están casualmente detenidos ó se han fugado del país - para obligarlas a que se negaran a dar publicidad a Oiga argumentando un sin fin de razones, entre ellas el mismo acoso que se venía tramando y efectuando contra la revista de Paco Igartua. Y como en un efecto dominó, las grandes imprentas, temerosas de sufrir represalias o de no ganar las licitaciones y concursos públicos convocados por el Gobierno para ser proveedoras del Estado, se negaron entonces a dar créditos o a imprimir la revista Oiga. Las imprentas que insistieron en editar la revista recibieron el mismo trato que recibían los anunciantes publicitarios independientes; y, por último, los funcionarios de la Sunat pusieron la mira directamente sobre los clientes de Eusko-Andina, que comenzaron a ser presionados tributariamente para que no apoyaran económicamente a la revista de Paco Igartua. Asimismo, el crédito financiero desapareció completamente, pese a que la empresa Editora Eusko-Andina siempre había honrado todos sus créditos y pagado fielmente todos sus impuestos, mientras que otras empresas, que mantenían deudas altísimas, recibían toda clase de facilidades crediticias. De todas formas, el apoyo de los lectores creció con mayor fuerza, pero por desgracia no fue suficiente y Oiga tuvo que prepararse para su inevitable cierre y salida de circulación. Aparentemente, la represión de la dictadura estaba logrando sus propósitos. 
Aunque la última agonía de Oiga, en 1995, duró varias semanas, conviene recordar, como ya hemos visto, que este drama empezó a gestarse dos años atrás, precisamente cuando el 12 de julio de 1993, a tres meses de cumplirse el primer aniversario del "autogolpe" de Alberto Fujimori (5/4/1992) -que disolvió el Parlamento y se convirtió en dueño absoluto del país con la complicidad de un grupo de militares corruptos-. Aquella histórica "primicia" del "Plan Verde" fue entonces el móvil fundamental que empujó a la dictadura a realizar la acometida que llevaría a la revista a su cierre definitiva: por haber dicho la verdad. Se trataba, a resumidas cuentas, de la denuncia sobre la existencia desde 1989 de un siniestro proyecto nacional diseñado al final del primer gobierno de Alan García por quienes pretendían perpetuarse en la Casa de Pizarro, el Palacio de Gobierno de Lima, y convertir al Perú en pasto de los apetitos de poder del entonces candidato a la presidencia, Alberto Fujimori. Era Notorio que el destino de la revista Oiga, de Paco Igartua, que había nacido un 8 de noviembre de 1948 defendiendo el respeto irrestricto a la libertad de expresión, y también la constitucionalidad y el estado de derecho -pues nació justo cuando el general Manuel A. Odría se había apoderado del poder mediante un golpe de estado-, debía morir en las mismas circunstancias: defendiendo el respeto irrestricto de la libertad de expresión, y también la constitucionalidad y el estado de derecho -pues el Perú en ese momento estaba viviendo una dictadura corrupta, la de Alberto Fujimori-. La historia dirá, entonces, aunque muchos han pretendido ignorarlo y hasta "olvidar" solapadamente que alguna vez existió una valiente revista llamada Oiga y un gran periodista que utilizó sus páginas para realizar el periodismo más digno de la historia peruana. Y la historia del periodismo peruano tendrá que reconocer alguna vez, para no seguir cayendo en la vergüenza de no haber escuchado y hecho caso cuando pudo hacerlo, que don Francisco Igartua Rovira, director de la revista Oiga, advirtió a sus colegas, pidiéndoles su apoyo, para denunciar que el objetivo de aquel siniestro "plan" no era 
otro que someter al Perú bajo uno de los regímenes más corruptos, represores y despiadados jamás vistos en nuestra desconcertante historia.

\subsection{El "acuerdo" del Pentagonito}

Otro de los episodios oscuros de esta historia, que el público peruano desconoce o conoce muy poco, por la campaña desinformación que se tendió sobre este y otros asuntos relacionados con lo que realmente sucedía en la época de Alberto Fujimori, fue el llamado "acuerdo del Pentagonito" (Nota 23), un vergonzoso cónclave entre los diversos Medios de Comunicación y el gobierno fujimorista que literalmente hipotecó el futuro del periodismo peruano. El propio Paco Igartua, en la parte final de su obra "Huellas de un destierro", además de relatar mejor que nadie este penoso periplo final de Oiga (1993-1995), nos informa sobre aquella reunión mediática convocada por el fujimorismo en diciembre de 1993, cuando los medios de comunicación se reunieron con Santiago Fujimori, hermano del entonces presidente, y otras personalidades del régimen, en el Cuartel General del Ejército Peruano, más conocido como "El Pentagonito", para re-negociar las enormes deudas tributarias de las empresas periodísticas con la Sunat. Fue una reunión a la que no fue invitada la revista Oiga -cuya deuda, sin embargo, no ameritaba el maltrato tributario y publicitario que venía sufriendo-, la misma que, sin embargo, asistió "furtivamente" en la persona de su director, Paco Igartua, con los resultados que veremos a continuación. El relato, por cierto, finaliza con una serena reflexión de la realidad peruana bajo la peor dictadura de nuestra historia: XLIV "Y sigo andando" (...) (Nota 27) ¿Por qué hoy, pues, tanta insistencia en el retiro, la jubilación, el cierre de Oiga, la tristeza del abandono de ciertas amistades?... Porque así está hecha la vida, de barro ardiente. Pero nada de lo enumerado significa rendición. En estas páginas no hay una línea pidiendo chepa y si guerra, guerra total contra el abuso, el atropello, la injusticia. Y si yo he cambiado de trinchera y me refugio ahora en la escritura, no es 
porque he variado en mis adentros. Simplemente ocurrió que me fue imposible seguir teniendo abiertas las puertas de Oiga. Me lo imposibilitó la represión taimada del régimen de los 90, una represión sesgada que deja la protesta en el vacío y amenaza con la cárcel por defraudación tributaria. He aquí esa penosa historia:

A fines de 1993, todos los periódicos, radios y televisoras - con excepción de El Comercio, Gestión y Canal 5- estaban quebrados. Se les habían acumulado millonarias deudas con la Sunat que crecían a velocidad geométrica por las moras y las multas. En teoría, el cierre de todos los medios de expresión -salvo las excepciones señaladas - era inminente... Dentro de esta situación Oiga se hallaba en una situación especial. Hasta hacia pocos meses había estado entre las excepciones, pues sus continuos desencuentros con distintos gobiernos obligaban a su administración a estar al día en los tributos, pieza clave para ajustes de cuenta con el Estado... Pero de pronto se había colocado en la disyuntiva de pagar la planilla de empleados o el impuesto del 18\% a la venta del periódico, impuesto abusivo que no existe en ningún país que respete la cultura... La decisión había sido cubrir la planilla, ya que de lo contrario no aparecía la revista... Y de esta forma se inició también en Oiga el huaico de las multas y las moras... Su deuda global en esos momentos era, sin embargo, una insignificancia al lado de las otras publicaciones, aunque de cifras imposibles de cancelar para la debilitadísima economía de Oiga, castigada sin piedad por el sabotaje publicitario del Estado y de los amigos del gobierno y, además, descapitalizada por el esfuerzo que había hecho para estar al día en el pago de tributos...

En tales circunstancias, los directivos de la prensa acogotada por la Sunat, acuden donde el señor Santiago Fujimori, quien, por intermedio del publicista Óscar Dufour, era el hombre del régimen encargado de las relaciones con los medios de difusión. Para ello y para otros menesteres, Santiago Fujimori digitaba a la Sunat (todas las 
noches esta entidad le daba un informe detallado de sus actividades). Pero a esa reunión no se invitó expresamente a Oiga- Fue el único periódico con problemas excluido de ese cónclave en el que se llegó al acuerdo de que los medios cancelarían sus deudas con la Sunat colaborando con el gobierno en un gigantesco programa educativo.

A la reunión para concretar este acuerdo, sí fui invitado, porque, al parecer, no se quería que alguien de la oposición quedara excluido del arreglo, para que nadie estuviera libre de paja para criticarlo.

La citación la hizo el señor Alfredo Jailile, el hombre de la Caja del Ministerio de Economía y brazo derecho del poderoso ministro Jorge Camet, y el encuentro se produjo en el Ministerio, presidido por Jalilie, con el señor Carlos Orellana a su lado, como delegado de Palacio. También asistía el señor Federico Prieto Celi, del Ministerio de Educación, periodista de larga y limpia trayectoria, que se encargaría de monitorear el famoso programa de educación, cuyo objetivo era la impresión de millones de textos escolares y cuadernos que se haría en los talleres de diarios y revistas, etcétera, etcétera.

El acuerdo provisional acordado con el señor Santiago Fujimori -personaje central del régimen sin ningún cargo oficial responsable - era un enorme disparate.

-El proyecto no tenía pies ni cabeza - comencé diciendo, apenas se expuso la propuesta.

Prieto Celi, que había acudido con una serie de ayudantes y una ruma de modelos para escoger, abrió desconcertado los ojos, yo continué: 
-Sería un disparate imprimir textos escolares en papel periódico y más todavía usar ese papel para cuadernos. La propaganda a favor del gobierno le resultaría al revés, pues esos cuadernos no servirían para nada y los libros se desbaratarían en un dos por tres.

-Se podrían hacer en bond.

-Si las rotativas usan el bond nacional destruirían sus rodillos por el polvillo que suelta ese papel... Y si se usa el bond importado la lavada va a resultar más cara que la camisa: tanto por el precio de ese bond como por los impuestos aduaneros y el IGV para el papel.

Cara de desolación en la sala. Prieto Celi se achicó detrás de las rumas de sus modelos. También Orellana sintió inseguridad en el piso. Alfredo Jaililie quedó imperturbable y me dedicó unas palabras de elogio.

Otros, más realistas, propusieron un arreglo publicitario. Los medios pagarían sus deudas a la Sunat con avisaje estatal.

Mientras se producía el debate, yo, que soy lerdo para expresarme verbalmente y porque se me podrían escapar algunos ajustados exabruptos, me dediqué a poner por escrito mis puntos de vista contrarios por completo al arreglo, ya que la solución no estaba en llegar a comprometidos acuerdos con el gobierno sino liberar de cierta carga tributaria a la cultura, como el 18\% a las ventas, igual que en la mayoría por no decir en todos los países civilizados del mundo.... Y cuando se agotó el debate decidieron por el arreglo con avisaje, leí mi texto, que luego publiqué como editorial.

-No se pueden hacer excepciones con el IGV -fue la respuesta. 
-¿Y por qué se exceptúa el juego de bolsa, a las afps y a otras actividades puramente lucrativas?

-La prensa no es cultura. Lean El Mañanero -metió su cuchara un funcionario, lector sin duda de basura amarilla.

Si no leyera usted periódicos no tendría usted su geografía ni si historia al día. Sería usted un analfabeto cultural. No cultivaría, si la tiene, su educación cívica.

Sin embargo, más tarde, por presión de la administración de Oiga, que se aferraba ilusamente a esperanzas imposibles, cedí y acepté el "arreglo", que era muy simple: El tesoro público, o sea Jaililie, extendía un cheque por el monto de la deuda de cada empresa y ésta lo endosaba a la Sunat. A cambio de tan simple "arreglo", el responsable -en el caso de Oiga, yo - aceptaba un pagaré con el gobierno, poniendo de garantía casa, autos, cuentas corrientes, etcétera, etcétera. Mientras que el Estado prometía -sin documento - publicar avisos hasta cumplir con el monto del pagaré.

$\mathrm{Y}$, como estaba previsto, los anuncios o avisos se fueron publicando de acuerdo al capricho del régimen. Rápido y bien valoradas las notas en los periódicos amigos y lentas y mal pagadas en los órganos de la oposición radical.

-Podía haber sido nunca.

Por eso, apenas rescaté el comprometido pagaré, resolví liquidar Oiga, lo que no resultó fácil. Más mucho más complicado y difícil es desbaratar que crear una empresa. 
¿Y la prensa que tenía en orden sus cuentas con la Sunat?...

Cuando se produjo el acuerdo protestó airado el canal 5, con un argumento válido: no era justo que se castigara a los cumplidos... Por lo que fueron premiados los que estaban al día. Y a Oiga se le volvió a discriminar. No se quiso hacer caso al alegato de que su situación era especial, pues siempre habían estado en orden sus pagos al fisco, con lo que se había descapitalizado, y siendo su retraso reciente... no podía ser tratado igual con los que nunca pagaron y no se descapitalizaron.

Su alegato fue al tacho de basura.

Todo esto lo miro con frialdad y no me arrepiento ni me quejo...

La lucha por lo que yo creo es la verdad no cesa porque imponderables decisiones del destino, por mano del poder político de turno, me obligaron al cierre de las puertas de mi revista Oiga. Siempre quedará la revista, lo escrito en ella, como el testimonio vital de mi compromiso conmigo mismo y con mis deberes cívicos y mi bandera inabdicable de ayer y de mañana, de siempre... Testimonio que continúa con mis libros y colaboraciones en la prensa...

Así reflexiono ahora, a la distancia, mientras termino de escribir la nota que todos los jueves leo, a las ocho de la mañana, en los micrófonos de Radio Libertad, dirigiéndome a un público masivo -la modernidad lo califica con las letras " $\mathrm{C}$ " y "D"-, que seguramente está más interesado en la problemática menuda de los escándalos públicos que en la meditación cívica, pero en el que la siembra de inquietudes mayores no es un desperdicio. Además, como que con esas notas y esporádicas colaboraciones en El Comercio mi conciencia se pone a salvo. 
También pienso en el Perú y su futuro y, sin querer, mi atención se fija en el pasado, en ese territorio de desconcertadas gentes, en la caravana que se quedó en mitad del desierto, en la República Embrujada, donde más veces y mayor tiempo se obedeció a la voz de mando de los cuarteles que al mandato de las urnas; donde los breves ensayos de democracia han nacido, languidecido y muerto prematuramente a la sombra de los espadones cuartelarios. Y escucho a lo lejos la voz de Juan Ríos diciéndome: "Durante mucho tiempo los institutos armados desempeñaron el papel de perros de presa de la mal llamada oligarquía. El general Velasco -autor de la zoológica definición- intentó ubuescamente y sin participación popular el experimento de cambiar al Perú. El resultado inmediato de su obra fundamental -la reforma agraria - fue un desastroso traspié económico. Pienso, sin embargo, que, desde el punto de vista histórico, constituye un paso necesario que desgraciadamente no dio el régimen presidencial de Fernando Belaunde".

¿Tienen razón estas palabras del poeta Ríos? Entrañable amigo y guía en las horas más oscuras de Oiga, salvo en las anteriores a las decisivas del destierro a México.

Difícil la pregunta y más compleja aún podría ser aún su respuesta si en el más allá siguieran en funciones los oídos y las cuerdas vocales de carne y hueso. El amigo Juan, de podernos replicar el comentario con el temperamento de su envoltura terrena, de seguro nos daría una respuesta sangrienta y breve. Sería una frase tan dolorosamente cruel como su: "¿Cree usted que hay país...?", lanzado como respuesta a una pregunta que se le hizo sobre la patria, a la que mucho y muy honradamente quiso a pesar de haber quedado "podrida antes de madurar".

Con tanta pasión la amó que un día del año 80, antes de los resultados electorales, quiso rezar así en Oiga: "Me parece que desde la Independencia el Perú ha vivido en permanente crisis ética, intelectual, física, económica y social. Nos hemos podrido 
antes de madurar. En un país que nunca tuvo clase dirigente ni escala de valores, donde el ejército ha matado más compatriotas en represiones y motines que soldados extranjeros en defensa de nuestro mutilado territorio. El pueblo, ignaro y desnutrido, no ha llegado aún a ser verdaderamente pueblo. No es su culpa. Es nuestra culpa. Perdónanos Señor". (...)

Fragmento del libro "Huellas de un destierro", Capítulo XLIV "Y sigo andando" (Nota 27).

\subsection{La saga del Pasaje Parodi...}

Después de la edición del 11 de agosto de 1995, la revista Oiga desapareció de los quioscos sin previo aviso ante la extrañeza de sus lectores. Paco Igartua ya estaba pagando caro por la osadía de haber revelado dos años atrás los pormenores de aquel secreto "plan de gobierno" del fujimorismo, y por haberse opuesto desde un comienzo al "autogolpe" de 1992 y criticado los cruentos métodos oficialistas para librarse de criminales y gente inocente sin hacer distinciones de ningún tipo. Bajo la garúa pertinaz del invierno limeño, Paco Igartua, enfundado en su inconfundible poncho serrano, deambulaba frente al inmueble signado con el número 508, en el hermoso Paseo Parodi, en San Isidro, el último refugio al que se había trasladado su revista. Ya no había nada que hacer. El "emperador" le había bajado el dedo, y hasta personas a quienes había tendido la mano cuando no eran nadie -como fue el caso del entonces presidente de Essalud, Luís Castañeda Lossio, el mudo que ahora funge nuevamente de alcalde de Lima- se escondieron para no colocar avisos o no pagar los ya publicados, que hubieran podido inyectar un soplo de vida al moribundo.

Ante esta terrible carencia, Paco Igartua decidió entonces la venta de la residencia ubicada en la Calle Pedro Venturo \# 353, en la Urbanización San Antonio, distrito de 
Miraflores -el único local propio que tuvo Oiga en su larga historia-, y de todo cuanto pudiera convertirse en dinero para cancelar los beneficios sociales del personal de la revista. El 17 de agosto de 1995, veinte días antes de su cierre definitivo, salió publicada en la revista Caretas una breve nota de prensa donde se anunciaba la próxima salida del número del adiós de Oiga, que fue preparado con el aporte de entrañables amigos y la colaboración desinteresada de su personal; la revista reapareció por última vez el 5 de septiembre de aquel año, en un número de colección -\# 756 de la V Etapa - en cuya portada aparecía el siguiente rótulo: "Adiós, con la satisfacción de no haber claudicado". En su editorial de despedida, Paco Igartua explicaba que Oiga cerraba para no prostituir sus banderas, o sea, esos ideales que fueron y son los de los peruanos amantes de las libertades cívicas, de la democracia y de la tolerancia, aunque seamos intolerantes con la corrupción, con el juego sucio de los gobernantes y de sus autoridades.

Ni los cuartelazos ni los exilios pudieron con él; y aún estando en países amigos, dio cátedra de periodismo decente. Paco Igartua no se rindió ante el hecho consumado, empero, y en un último gesto de rebeldía y esperanza pregunta a sus lectores: ¿Por qué el cierre de esta quinta etapa de la azarosa existencia de Oiga no puede significar solamente un alto en la batalla? ¿Por qué tiene que ser imposible una sexta y hasta una séptima vida, como los gatos?

Finalmente, después de vender el local de Miraflores, cerrar la revista y entregar la sede alquilada de Paseo Parodi, Paco Igartua tuvo que tomar una terrible decisión: vender la marca de la revista Oiga para poder pagar los beneficios sociales de los 70 trabajadores de su empresa. Hay gestos que uno no sabe como salen, pero brotan del alma, como las lágrimas; no es fácil para un hombre de bien como Paco Igartua escoger entre el facilismo y la dignidad -pues se le recomendó no vender la marca Oiga... Pero escogió lo que el deber le decía: procurarse de los medios para poder 
cumplir con sus obligaciones tributarias y también para cancelar los beneficios sociales de los 70 trabajadores de la revista Oiga. Fue un gesto que lo enalteció ante Dios y ante los hombres.

Después de la edición del último número -el \# 756 del 5 de septiembre de 1995-, el local ubicado en Pasaje Parodi de San Isidro quedó casi vació. Una versión cuenta que en ese momento todos ya se habían retirado con su última liquidación y don Paco se encontraba solamente con la administradora del local, Gloria Fernández, ya que la Gerente General ya había terminado con las labores administrativas de rigor. El inmueble había sido alquilado por todo un año -y por medida de seguridad, este alquiler había sido cancelado por todo el periodo contratado y ya no había nadie encargado de ver por su seguridad. El archivo fotográfico había sido saqueado sistemáticamente en las últimas semanas, y todas las maquinas e implementos de oficina se encontraban completamente abandonados. El panorama, pues, era desolador, y el cierre y entrega del local se había fijado para el 24 de marzo paradójicamente, nueve años después, el mismo día fallecía Paco Igartua-. En la víspera, un amigo de Paco, Felipe Carbonell, se había ofrecido a guardar los últimos muebles de la oficina que nadie había querido llevarse. Ese día, Paco estuvo por última vez en el local, y converso con la administradora sobre cómo había sido el regreso de la Oiga 78, y el inicio de la V y última etapa de la revista. Luego se despidió de Gloria y se retiro.

Al momento de retirarse, Gloria Fernández le echó una última y nostálgica mirada a aquellos ambientes ahora totalmente silenciosos, dio un suspiro y apago la luz. Al día siguiente entregó las llaves del local a su propietario. Todo había terminado mientras alrededor la vida de la ciudad seguía su curso como si nada hubiera pasado. 
La venta de la revista Oiga simboliza la fuerza del temple que puede tener un ser humano ante la adversidad: don Paco no era uno de esos cientos de empresarios que en los '90s cerraban sus empresas con el cuento de la insolvencia y dejaban a su personal botado en la calle. Honrar sus deudas fue lo que lo diferenció de aquellos en quienes la caballerosidad no era precisamente una cualidad. Él prefirió luchar contra esta última tentación "no la vendas y mejor llévate la marca a tú casa", y cual Francisco de Asís, el nos marcó el camino del "debe ser": antes que cualquier cosa, prefirió separarse de la niña de sus ojos para que a ningún trabajador de la Empresa Eusko-Andina le faltara el pago de sus beneficios sociales.

Nada... o casi nada quedó de esa pasión por la verdad y el teclear de las máquinas de escribir, salvo la gratificante pero también amarga memoria, y mientras todo esto sucedía, y la revista Oiga quedaba en el ayer, y luego se vendía, la historia del Perú reciente seguía su curso de la manera más grotesca. El siniestro protagonismo de Vladimiro Montesinos, al final, vería hundirse su imperio de la corrupción torpedeado por sus propios "vladivideos"; aquella corrupción institucionalizada que pudrió la salud moral y la dignidad del país terminó convirtiéndose en una trampa para quienes medraban en el falso limbo de los impunes. El régimen autoritario de la re-reelección acabó en una vergonzosa y cobarde huída del "peruano japonés" a la tierra de los kimonos. Y como fieles a aquello de "si yo caigo, tu también caes", y cayó. El "doc" terminó fugando a Panamá y de allí a la chavista Venezuela, país donde finalmente sería capturado para ser traído de vuelta al Perú. El poder del fujimorismo y sus acólitos, empero, no se terminó del todo con la caída de sus líderes... que no murieron en su ley... sino en la de otros; la "gripe indefinida" que los volvió locos de poder le pasó el "virus" a la "dicta-blanda" sin pies ni cabeza de Alejandro Toledo Manrique, el pintoresco e irrepetible cholo sano y sagrado (sic. Frase de su esposa, Eliane Karp, sin duda una de las peores "primera dama" de la historia peruana. N. de R), quien fue presidente del Perú entre el 2001 y el 2006, y allí 
fueron a parar todos los piojos y las pulgas, que sino las moscas, sobrevivientes a la masacre de los "vladivideos" del año 2000 -las cintas que revelaron toda la corruptela del gobierno de Alberto Fujimori, un escándalo que precipitó la caída del régimen-, y a ellos, como era de esperar, se sumaron otros "angelitos", los allegados al entonces mandatario de turno (Toledo). Durante la gestión de la "chacana" (Nota 30); casi todos los corruptos "chicos", los oportunistas que se aprovecharon de las "bondades" del fujimorismo, estuvieron allí con el mayor desparpajo, aunque también con algunos de ellos prófugos y otros en prisión. Mejor suerte corrieron algunos de los "peces gordos" de la mafia fujimontesinista, quienes se las arreglaron para seguir en la impunidad más absoluta, como ha sucedido con el ex ministro de Economía Juan Carlos Hurtado Miller, libre a pesar de haber recibido dinero de Montesinos, y el ex director del diario Expreso, Eduardo Calmell del Solar, hoy refugiado en Chile tras su escandalosa fuga del Perú en el 2004, cuando iba a ser enjuiciado por recibir un soborno del "doc" y por enriquecimiento ilícito, y Ernesto Schütz Landázuri, dueño de Panamericana Televisión, quien se fugó a Argentina y luego a Suiza cuando iba a ser procesado por recibir dinero de Montesinos en la famosa salita del SIN. Y de la selva que fue esa dictadura todavía quedaron ciertos animalotes, los elefantes furiosos de la burocracia y la demagogia -la corruptela de bufete-, nuevo fortín de los últimos pero aún poderosos remanentes de régimen que mantuvo al Perú bajo la oscura tutela de sus peores demonios y ángeles caídos.

\section{Notas al Margen y Referencias}

(Nota: A la derecha de los hipervínculos se ha insertado la fecha de última apertura de la página Web citada)

1. V Etapa \# 647, pp. 9 - 15 
2. Distrito ubicado al este de las periferias de Lima, a orillas del río Lurín, lugar donde abundan los descampados, basurales y terrenos eriazos.

3. El autor del reportaje se refiere, por cierto, a las "parajes desolados", es decir, a las punas y llanuras andinas, donde se desarrollaba la lucha antiterrorista, y también la "guerra sucia" -esto es, las matanzas provocadas por las FFAA sin distinguir entre terroristas o gente inocente-, antes de que ésta se trasladara a las ciudades de la costa, particularmente a Lima.

4. Como se verá en estas líneas y en las que siguen a continuación, esta presunción de Oiga fue prontamente confirmada.

5. Siglas del Servicio de Inteligencia del Ejército.

6. Art. Cit. V Etapa \# 647

\section{Art. Cit. V Etapa \# 647}

8. Por aquella época -años 90 -, a todo militar peruano, sobre todo si era del Ejército, lo llamaban "pajarillo vede", por el típico color verde oliva de su uniforme. Y, como era obvio, el individuo uniformado no se identificó... o pidió guardar en reserva su nombre.

9. V Etapa \# 647, pp. 22-32

10. V Etapa \# 648, pp. 30-35 
11. Aprosubversiva, término acuñado de forma sin duda antojadiza por los redactores de la primera parte este "plan", que luego sería reiterada en diversas partes de este documento; a todas luces se trataba de una palabreja anodina que en aquel tiempo no era utilizada ni siquiera por la prensa sensacionalista (periodismo chicha).

12. Fredemo. El Frente Democrático que liderara el escritor Mario Vargas Llosa contra la candidatura de Alberto Fujimori en abril de 1990. Los redactores del "Plan Verde" veían en este movimiento una amenaza latente para las aspiraciones del futuro régimen "cívico-militar" que querían implantar en el Perú.

13. Para ilustración de los amables lectores, este adverbio (del latín sic, así) que tanto venimos repitiendo en este trabajo es un vocablo que "se utiliza en los textos escritos en español, normalmente entre paréntesis, para indicar que la palabra o frase que lo precede es literal, aunque sea o pueda parecer incorrecta. Se usa cuando se reproducen errores, tipográficos o de otra clase, o inconveniencias al citar textos, para informar al lector que el uso indebido se encuentra en la fuente original y no es obra del que cita. Ejemplos: «me llenastes [sic] un barril», «para combatir al indio (sic)», «me robaste la amoto [sic]», «hago unas cloquetas [sic] de arrechupete [sic]». El uso más frecuente es éste, en el que con frecuencia se trata de mostrar una debilidad, una falta ortográfica o un juicio descabellado, en quien es citado." Texto de Wikipedia.

14. Art. Cit. \# 648

15. De "Los 'anexos'..." Art. Cit. \# 648 
16. Respecto a este punto, un trabajo publicado en el sitio Web de la ONG española PROVIDA, titulado: LA ESTERILIZACION FORZADA EN EL PERÚ, que cita como fuente el informe final de la Comisión Especial que el Ministerio de Salud del Perú formó para investigar las denuncias sobre esterilizaciones forzadas durante el decenio de Fujimori en las regiones empobrecidas de la sierra y la Amazonía peruanas, señala lo siguiente (Nota: el texto a continuación tiene algunas fallas ortográficas. N. de VA): "...pero, ¿en qué consistió dicho Plan? El Informe de la Comisión Especial menciona al respecto que: Según testimonios, desde 1994 un grupo de 25 militares asimilados al Ejército, la Marina, la Fuerza Aérea, la Policía Nacional, fueron reclutados y destacados a laborar en un Proyecto de Estado, éste fue denominado Plan de Contingencia y Emergencia AQV. Dicho militares, en su mayoría médicos, tenían como misión estudiar, analizar y crear un proyecto que frene las altas tasas de natalidad a nivel nacional. Para optimizar esta labor la delegación de militares realizó cursos en Japón y Estados Unidos, llegando a determinar que, las intervenciones quirúrgicas para la esterilización forzada debían ponerse en marcha .". aplicar un plan que pretenda la eliminación del excedente poblacional y los sectores nocivos de la población. Consideramos a los subversivos y a sus familiares directos, a los agitadores profesionales, a los elementos delicuenciales y a los traficantes de pasta básica de cocaína como excedente poblacional nocivo (...) para estos sectores dado su carácter de incorregibles y la carencia de recursos (...) sólo el exterminio total".

Este sustento, añade el Informe antes aludido, se encuentra desde 1989, en lo que hoy se conoce como Plan Verde, añade que, esto mismo, sirvió de base a los militares destacados a elaborar el Plan de Contingencia y Emergencia del AQV (P.C.E.).

El P.C.E. extrae del Plan Verde: "... ha quedado demostrada la necesidad de frenar lo más pronto posible el crecimiento demográfico y urge, adicionalmente, un 
tratamiento para los excedentes existentes, elevando la utilización generalizada de esterilización en los grupos culturalmente atrasados y económicamente pauperizados. Sin estas cargas innecesarias, se facilitará el acceso de grupos familiares débiles a ciertos niveles de bienestar..." (Informe Final de la Comisión Especial sobre actividades de Anticoncepción Quirúrgica Voluntaria, julio del 2002, pág. 74).

Finalmente, deseo compartir con ustedes el hecho que si bien en el Congreso de la República la investigación sobre las AQVs ha sido archivada, lamentablemente, por alianzas políticas que, aunque cueste entenderlo, se han resistido a que el Poder Judicial investigue estos hechos y que el pueblo peruano y la comunidad internacional sepa LA VERDAD de lo que ocurrió, el Ministerio Público, es decir, la Fiscalía de la Nación, ha iniciado, en base a nuestra denuncia, una sólida investigación, inclusive, la señorita Fiscal de la Nación, en el diario español "El País", (30 de abril de 2003), ha declarado que se denunciará al ex Presidente Fujimori por el delito de Genocidio por las esterilizaciones forzadas en mi país, lo cual me llena de satisfacción y estoy convencido que a ustedes también, pues los que estamos en este Congreso creemos en la vida y en el respeto a la integridad física, psíquica y moral del ser humano." Texto de Héctor Chávez. (Ver más información en el sitio: http:/ / www.provida.es/pensamiento/Publicaciones/Hector_Chavez.htm) (3/9/08)

17. Con toda seguridad corresponden al Centro de Altos Estudios Militares (CAEM) -paradójicamente, uno de los institutos de enseñanza castrense más prestigiosos de Latinoamérica - , con sede en el distrito limeño Chorrillos.

18. Léase: Superintendencia Nacional de Administración Tributaria (Sunat)

19. Oiga V Etapa \# 724 
20. V Etapa \# 755, pp. 3

21. Véase al respecto el blog "Desde el tercer piso" con un interesante artículo y contenido gráfico ("Tarata: Memoria del Olvido") http:/ / www.desdeeltercerpiso.com/2008/07/tarata-memoria-del-olvido/ (27/8/08)

22. "Adiós Amigos y Enemigos" fue el corolario de una fecunda carrera periodística en la que don Francisco Igartua Rovira nació, vivió y murió defendiendo la constitucionalidad y el Estado de Derecho en el Perú, y que prefirió cerrar su revista antes que vender su impecable línea editorial que durante décadas fue el terror de dictadores y corruptos. En su último editorial, bajo este título, don Paco, cual figura señera del periodismo peruano, escribió:

En cualquier despedida algo se va de nuestra existencia y en cada adiós morimos un poco. Y siendo éste un adiós con resonancias mayores, grande es la sensación de acortamiento de la vida que acompaña a mi lápiz en estas líneas, aunque en el cerebro se me vaya afirmando la esperanza de que este adiós sólo será un alto en la larga batalla de OIGA por lograr que los ciudadanos del Perú comprendan que el verdadero desarrollo se logrará únicamente cuando construyamos una democracia, cuando hagamos de esta patria nuestra un estado de derecho, basado en el imperio de la ley. ¿Por qué el cierre de esta quinta etapa de la azarosa existencia de OIGA no puede significar solamente un alto en la batalla? ¿Por qué tiene que ser imposible una sexta y hasta una séptima vida, como los gatos, insistiendo en que los grandes programas económicos, los brillantes empréstitos, la magia de las finanzas, las apabullantes obras físicas, el crecimiento espectacular del turismo, no serán reales, sino sólo apariencias, si los peruanos siguen apartados de la cultura cívica, sin entender que el meticuloso respeto a la ley -tanto de los de arriba como los de abajo - es el único cimiento sólido para un desarrollo verdadero y sostenido? 
Aunque, desgraciadamente, no es del porvenir -aún muy incierto - que me toca tratar en esta nota editorial. Me corresponde referirme a los hechos puntuales del presente, o sea repetir lo que escribí hace dos semanas a mis amigos: OIGA ya no volverá a aparecer. Después de 33 años de llegar semanalmente a manos de nuestros lectores -salvo algunas interrupciones, unas breves y otras prolongadas, motivadas por clausuras y una deportación en México - queda interrumpido este largo diálogo que veníamos sosteniendo con nuestros lectores.

¿Diálogo?, se preguntarán con sorna más de uno de los lectores de OIGA que no nos quieren y responderé diciendo con el maestro Unamuno que, bueno, que no serán diálogos -tan inservibles como esos catecismos con preguntas y respuestas - sino autodiálogos, diálogos consigo mismo, con las inquietudes que en mí despertaba la actualidad y los problemas que esa actualidad creaba en mi conciencia.

OIGA ya no volverá a aparecer. La cierra, no obliga a autosilenciarnos, el acoso que la revista viene sufriendo desde hace diez años. He tomado esta decisión en consulta con mis asesores más cercanos, principalmente con Jesús Reyes, quien me viene acompañando casi desde el día -hace 33 años - que retomé la aventura de OIGA, iniciada en noviembre de 1948, como respuesta de mi generación al cuartelazo del general Odría contra el presidente Bustamante y Rivero, el hombre que inútilmente intentó que este país de desconcertadas gentes entendiera el valor de la democracia, de la cultura cívica, del acatamiento al imperio de la ley y no al mandón de turno.

Cierra OIGA para no prostituir sus banderas, o sea sus ideales que fueron y son de los peruanos amantes de las libertades cívicas, de la democracia y de la tolerancia, aunque seamos intolerantes contra la corrupción, con el juego sucio de los gobernantes y de sus autoridades. El pecado de la revista, su pecado mayor, fue quien sabe ser intransigente con su verdad -con lo que cada uno cree es lo cierto - y 
en el curso del camino fuimos perdiendo amigos, contactos, benefactores, sobre todo amigos que alguna vez encontraron acogida en estas páginas y cuyas causas defendió OIGA con calor.

Pero ¿qué importa lo ganado o lo perdido en la ruta? Sí me importa morir con dignidad, con la altivez con que vivimos estos últimos 33 años de Historia del Perú.

He dicho que hubo acoso y podría relatar las presiones sufridas por la imprenta donde se imprimía OIGA -imprenta permanente perdedora en las licitaciones a las que acudía - pero no quiero crear problemas a terceros que actuaron con entereza hasta que se les quebró el ánimo de ayudarnos. Hablaré, pues, de acoso sin añadir detalles, dejaré la palabra colgada en el aire. Y en cuanto al acoso tributario sí seré algo más preciso, por la ayuda que desde estas últimas páginas puedo prestar a mis colegas de la prensa escrita, colocados en situaciones parecidas a las que han llevado a OIGA a decir adiós a sus lectores.

Sí hay acoso tributario y es penosa la voz de los fundamentalistas del liberalismo, de los ayatolas del fujimorismo, cuando gritonean que no debe haber excepciones en las normas tributarias al referirse a los impuestos al papel y al IGV sobre la venta de periódicos y revistas -IGV que no puede ser trasladado a los canillitas - y callan, poniéndose siete candados en la boca, cuando se exceptúa del IGV a los negocios de la educación, cuando se libra de IGV a los negocios en la Bolsa y cuando el Estado excluye de ese impuesto -para que no quiebren - a las AFPs.

Sí hay un acoso tributario contra la prensa, que se hace extensiva a los libros, a la lectura en general. Y haciendo prohibitiva la lectura, justo en el quinquenio de la Educación, se escarnece al más elemental derecho de un educando: poder leer con libertad. (Entendiéndose por educandos no sólo a los párvulos de los colegios sino 
también a los mayores, quienes sólo leyendo se irán graduando en una materia en la que no se cesa de aprender, en cultura cívica). También es burla cruel mantener ese 18\% de IGV a las medicinas y a los alimentos básicos en un país de tuberculosos, muertos de hambre y con salarios miserables. ¿Por qué? -repetimos como tantas otras veces - se ensaña la tributación con la cultura, la salud y la alimentación básica y sí encuentra razones para ser benévola con las especulaciones financieras, las AFPs y las empresas que hacen negocio con la educación?¿Por qué en el Perú del quinquenio de la educación se hace prohibitivo leer un libro?

$\mathrm{Y}$, para terminar esta nota de adiós, debo decir gracias, muchas gracias, a todos los colegas que han expresado públicamente su pesar por la desaparición de OIGA. En especial, el decano de la prensa nacional, a El Comercio; a César Hildebrandt, que me emocionó ante las cámaras de Canal 9; a María del Pilar Tello, de Gestión; a Mirko Lauer, de La República; a Juan Ramírez Lazo... Y no sigo enumerando a las voces de solidaridad recibidas, tanto de encumbrados personajes -el presidente Belaunde y el embajador Pérez de Cuéllar, entre otros - como de viejos colaboradores y de amigos de la revista que apenas conocí, porque estoy seguro que los olvidos serían muchos más que los recuerdos y yo quisiera que las gracias sean para todos por igual. Francisco Igartua.

Editorial del número del Adiós de Oiga, publicado el 5 de septiembre de 1995

23. El "Pentagonito". Nombre con el es conocido, vulgarmente, es un enorme complejo militar construido en el distrito limeño de Surco durante el gobierno del general Juan Velasco Alvarado, presidente de facto entre 1968 y 1975, para tal fin. Se trata de una verdadera joya arquitectónica que incluye ambientes protegidos a prueba de explosiones atómicas, además de vastos compartimientos y grandes patios 
donde el dictador Fujimori solía también buscar refugio cuando la situación lo ameritaba.

24. Art. Cit. V Etapa \# 647, pp. 9 - 15

25. Art. Cit. V Etapa \# 647, idem.

26. Art. Cit. V Etapa \# 724, pp. 3

27. Grupo Santillana de Ediciones S.A., Lima, 1998, pp. 286 a 290

28. Sección Mar de Fondo, 17/8/95

29. Sobrenombre que recibía "Perú Posible", el partido político fundado por el polémico ex presidente peruano Alejandro Toledo Manrique (gobernante entre 2001 y 2006) Este nombre hacía referencia al símbolo de del mismo, una especie de cruz andina que antiguamente representaba a la constelación de la Cruz del Sur, es decir, la "chakana", por su grafía quechua.

30. De Las campañas psico-sociales en el gobierno de Alberto Fujimori. Santiago Stucchi Portocarrero / Guillermo Ladd Huarachi http://stucchi.tripod.com/politica/psico.htm (30/8/08)

31. Edición 1715, 04/03/03 Publicado en el sitio:

http://www.resistencia.org/documentos/cinco_abril/

cinco_abril_autogolpe_ali_baba.htm (30/8/08)

32. La podredumbre moral del fujimorismo. Artículo de El Mundo, Madrid. 
http://www.sosperiodista.com.ar/El-Mundo/

La-podredumbre-moral-del-fujimorismo (3/9/08)

33. Periodismo Comprado. Artículo publicado en "La botella al mar".

http:/ / www.labotellaalmar.com.ar/vertema.php?id=99 (3/9/08)

34. Violencia fujimorista...

http://albertodebelaunde.blogspot.com/2007/09/

violencia-fujimorista-cobra-primera.html (7/9/08)

35. Llorando de ira.

http:// menoscanas.blogspot.com/2007/09/llorando-de-ira.html (7/9/08)

36. Al cierre de edición: Fujimori trató de encubrir el abuso de derechos humanos, afirma perito - Noticia del diario El Comercio de Lima:

http://www.elcomercio.com.pe/ediciononline/HTML/2008-09-08/

fujimori-trato-encubrir-abuso-derechos-humanos-afirma-perito.html (15/9/08) 
